\title{
Neotropical Acanthoderini \\ (Coleoptera, Cerambycidae, Lamiinae): \\ Synonymies and new status in some genera, new species, transferences and new distributional records
}

\author{
Antonio Santos-Silva ${ }^{1,3}$; Juan Pablo Botero ${ }^{1,4}$ \& James E. Wappes ${ }^{2}$ \\ 1 Universidade de São Paulo (USP), Museu de Zoologia (MZUSP). São Paulo, SP, Brasil. \\ 2 American Coleoptera Museum. San Antonio, Texas, United States. E-mail: Iwappes@earthlink.net \\ ${ }^{3}$ ORCID: http://orcid.org/0000-0001-7128-1418. E-mail: toncriss@uol.com.br \\ ${ }^{4}$ ORCID: http://orcid.org/0000-0002-5547-7987.E-mail:jp_bot@yahoo.com
}

\begin{abstract}
Taxonomic notes are provided in some Acanthoderini genera. Three new species are described: Scythropopsis intricata Santos-Silva, Botero and Wappes from Mexico, Aegomorphus robustus Santos-Silva, Botero and Wappes and Eupromerella boliviana Santos-Silva, Botero and Wappes from Bolivia. The following synonymies are proposed: Psapharochrus Thomson, 1864 as synonym of Aegomorphus Haldeman, 1847; Acanthoderes (Psapharochrus) albomaculatus Fuchs, 1963 and Acanthoderes griseomaculata Zajciw, 1971 as synonyms of Symperasmus alboniger (Bates, 1861); Pteridotelus contaminatus Thomson, 1865 as synonym of Scythropopsis melanostictica (White, 1855); Psapharochrus jameswappesi Tavakilian, 2018 as synonym of Aegomorphus wappesi (Galileo, Martins \& Santos-Silva, 2015); and Psapharochrus histrio Casey, 1913 and Psapharochrus guatemalensis Casey, 1913 as synonyms of Aegomorphus circumflexus (Jacquelin du Val, 1857). Acanthoderus circumflexus Jacquelin DuVal, 1857 is proposed as nomen protectum and Acanthocinus rusticus Klug, 1829 as nomen oblitum. Aegomorphus contaminatus (Thomson, 1965) is revalidated. Scythropopsis Thomson, 1864 and Symperasmus Thomson, 1864 are herein elevated to genus rank. The geographical distribution of ten species is expanded and a key to differentiate Acanthoderes, Aegomorphus, Scythropopsis, and Symperasmus is provided.
\end{abstract}

Key-Words. Eupromerella; Miriochrus; Plagiosaurus; Sychnomerus; Taxonomy.

\section{INTRODUCTION}

The tribe Acanthoderini has a cosmopolitan distribution and is comprised of 66 genera and more than 560 species making it one of the largest tribes in the Lamiinae (Tavakilian \& Chevillotte, 2019). Most Acanthoderini genera and species are geographically restricted to the Neotropical Region. In this region there is a group of closely related genera whose taxonomy is confusing, which has resulted in species allocated to them that do not fit the current definition of the genera further complicating an already confusing situation.

Herein, the definition and limits of these closely related genera: Acanthoderes AudinetServille, 1835, which is subdivided in four subgenera, A. (Acanthoderes), A. (Pardalisia) Casey, 1913, A. (Scythropopsis) Thomson, 1864, and A. (Symperasmus) Thomson, 1864; Aegomorphus
Haldeman, 1847; Eupromerella Fisher, 1938; Miriochrus Galileo \& Martins, 2012; Plagiosarus Bates, 1880; Psapharochrus Thomson, 1864; and Sychnomerus Bates, 1885 are defined to validate each. As a result, numerous taxonomic changes are proposed. Additionally, three new species are described, and new geographical records listed for ten species.

\section{MATERIAL AND METHODS}

Photographs were taken in the MZSP with a Canon EOS Rebel T3i DSLR camera, Canon MP-E $65 \mathrm{~mm}$ f/2.8 1-5X macro lens, controlled by Zerene Stacker AutoMontage software. Measurements were taken in "mm" using a measuring ocular Hensoldt/Wetzlar - Mess 10 in the Leica MZ6 stereomicroscope, also used in the study of the specimens. 
The acronyms used in the text are as follows:

ACMT: American Coleoptera Museum (James Wappes), San Antonio, Texas, USA

FSCA: Florida State Collection of Arthropods, Gainesville, $\mathrm{FL}$, USA

FWSC: Fred W. Skillman collection, Pearce, Arizona, USA

MNKM: Museo de História Natural Noel Kempff Mercado, Santa Cruz, Santa Cruz, Bolivia

MNRJ: Museu Nacional do Rio de Janeiro, Rio de Janeiro, Rio de Janeiro, Brazil

MZSP: Museu de Zoologia, Universidade de São Paulo, São Paulo, Brazil

RFMC: Roy F. Morris Collection, Lakeland, FL, USA

SWLC: Steven W. Lingafelter Collection, Hereford, AZ, USA

\section{TAXONOMY}

\section{On Acanthoderes Audinet-Serville, 1835, Aegomorphus Haldeman, 1847, Psapharochrus Thomson, 1864, Scythropopsis Thomson, 1864, Symperasmus Thomson, 1864, and Sychnomerus Bates, 1885}

The definitions of the above acanthoderine genera have seen numerous changes since their original descriptions. These changes have resulted in modifications in their status (some more than once) making for a complicated history. In the most part their original descriptions have not allowed taxonomists to clearly understand their limits, and as a result new species have been assigned to them that changed their limits. Thus, making the study of this group of genera even more complicated and difficult. Santos-Silva \& Nascimento (2018) commented about the differences between Acanthoderes and Psapharochrus, and reported: "Apart from those controversial classifications, it was Lacordaire (1872) who provided the best feature to separate Psapharochrus (including Symperasmus as a synonym) from Acanthoderes (Acanthoderes) and A. (Scythropopsis). The former was included among the genera with eyes coarsely or sub-coarsely granulated, while the two latter genera were included among those with eyes finely granulated." Lacordaire (1872) also included Aegomorphus in the group of genera with eyes coarsely granulated, and separated it from Psapharochrus in the key by the genal length (translated): "Genae very short, sometimes nearly absent", leading to Aegomorphus; and "Genae, at least, with medium size", leading to Psapharochrus. However, the genae in the type species of Aegomorphus, Aegomorphus decipiens Haldeman, 1847 (Figs. 4-6) (= Lamia modesta Gyllenhal, 1817 (Figs. 41) = Aegomorphus modestus), is distinctly long, as in the type species of Psapharochrus, Acanthoderes cylindricus Bates, 1861 (Figs. 7-9). Actually, the genal length is longer in the type species of the former than in the latter, and Aegoschema sensu Lacordaire (1872) is equal to Aegoschema Aurivillius, 1923. This becomes clear when seeing the species originally includ- ed in Aegomorphus by Lacordaire (1872): A. adspersus Thomson, 1861; A. moniliferus White, 1855; and A. obesus Bates, 1861. But it is curious to note that Aegomorphus decipiens Haldeman, 1847, type species of the genus, was included in Psapharochrus by Lacordaire (1872). The problem here was that Lacordaire (1872) wrongly attributed the authorship of the Aegomorphus to Thomson (1861), considering Aegomorphus Haldeman as a synonym of Psapharochrus. Evidently, thus occurred because Haldeman (1847) attributed the authorship of Aegomorphus to Dejean (1835) followed by a correction of this by Aurivillius (1923): "Aegoschema n. nom. / Aegomorphus Thoms. (nec Hald. 1847)."

Santos-Silva \& Nascimento (2018) summarized their conclusions as follows:"1. Symperasmus - probably a synonym of Psapharochrus, but, at least, it must be considered a subgenus of Psapharochrus. 2. Pardalisia - probably a synonym of Acanthoderes; 3. Scythropopsis - probably a genus distinct from Acanthoderes; 4 . Eyes very finely granulated - Acanthoderes (Acanthoderes); A. (Pardalisia); A. (Scythropopsis). 5. Eyes coarsely or moderately coarsely granulated - Psapharochrus; A. (Symperasmus)." However, at that time they did not formally propose any change in the status of those genera.

A study of the type species of Aegoschema and Psapharochrus has revealed that they share the same features and lack significant differences hence we conclude that they are not different genera. Accordingly, we formally synonymise Psapharochrus with Aegomorphus. Although, it is important to note that several species currently placed in Psapharochrus which have the lateral tubercles of the prothorax with the apex blunt (not acute as in the type species) and the elytra gradually narrowed from humerus to apex (not parallel-sided as in the type species), indicates that they are likely not true Psapharochrus and thus, not Aegomorphus either.

Following the conclusions of Santos-Silva \& Nascimento (2018), we also consider both Scythropopsis and Symperasmus to be genera distinct from Acanthoderes. However, Pardalisia Casey, 1913 will provisionally be kept as a subgenus of Acanthoderes.

The following key incorporates the primary characters needed to separate the genera involved in this study:

1. Eyes very finely granulated (Figs. 1-3, 10-12) ................................... 2

- Eyes slightly to distinctly coarsely granulated (Figs. 4-6, 7-9, 13-15).3

2(1). Elytra distinctly carinate dorsally (Fig. 10). Scythropopsis

- Elytra without carina distant from suture (Fig. 1) Acanthoderes (Acanthoderes) and A. (Pardalisia)

3(1). Pronotum (Figs. 13-14) with distinct central depression, from near base to near apex or only in anterior region, margined by lateral elevation (carinate or not) Symperasmus

- Pronotum (Figs. 4-5, 7-8) not distinctly depressed centrally, nor with lateral tubercles forming carina Aegomorphus

It is important to note that this study does not exclude the possibility that some species currently included (or transferred herein) in Acanthoderes, Aegomorphus, Symperasmus, and Scythropopsis may need a new genus. This is especially true regarding some species current- 
ly included in Psapharochrus, which differ considerably from the type species of the genus, and hence also Aegomorphus.

The species of Aegomorphus from the Palearctic region agree well with the type species of the genus in the body shape, prothoracic lateral tubercles, and pronotal tubercles. However, at least in one of the species examined by us, Aegomorphus clavipes (Schrank, 1781) (Figs. 16-18), the eyes are finely granulated as in the species of Acanthoderes and Scythropopsis.

According to Bates (1885) on Sychnomerus: "Two species of Central-American 'Aconthoderini' are here separated from Acanthoderes on the same grounds as Discopus, Pteridotelus, Tetrasarus, and Plagiosarus are separated, namely, differences in the clothing and structure of the antennae... The typical species of Sychnomerus has greatly the appearance of a Pteridotelus; but it wants the dentiform process of the undersides of joints 7,9, and 10 which characterize that genus; what seem to be such processes in Sychnomerus prove on close examination to be dense tufts of hair." He defined the genus as follows (translated): "A genus differing from Acanthoderes only by the antennomeres III-XI densely setose ventrally, and VII-XI very short in females, and with long and abundant setae." Examination of photographs of the types of the two species included in Sychnomerus, S. hirticornis Bates, 1885, and S. barbiger Bates, 1885 (see photographs at Bezark, 2019), suggests that they do not belong to the same genus because the body shape differs, and the erect setae on the ventral surface of their antennomeres is noticeably different. Sychnomerus hirticornis, the type species, appears to be Scythropopsis. However, in the species of this latter genus examined by us, the distal antennomeres in males often have the setae as in S. hirticornis and, usually, the "tufts" in the basal antennomeres also very similar or identical. However, the females of Sychnomerus do not have long setae on distal antennomeres. Accordingly, while specimens of S. hirticornis and S. barbiger were not available for study, we are keeping Sychnomerus as a distinct genus.

\section{Symperasmus Thomson, 1864 resurrection of the original status}

\section{Symperasmus alboniger (Bates, 1861), comb. nov. (Figs. 19-34)}

Acanthoderes alboniger Bates, 1861: 218.

Acanthoderes albonigra; Gemminger, 1873: 3145 (cat.); Blackwelder, 1946: 610 (checklist); Zajciw, 1969a: 198 (distr.); 1970a: 5 (distr.).

Acanthoderes (Psapharochrus) albonigra; Aurivillius, 1923: 385 (cat.); Gilmour, 1965: 615 (cat.); Monné, 1994: 57 (cat.); Monné \& Giesbert, 1994: 229 (checklist).

Psapharochrus alboniger; Lacordaire, 1872: 751; Monné, 2005: 200 (cat.); Monné et al., 2012: 32 (distr.); Monné, 2019: 289 (cat.).

Psapharochrus albonigrus; Wappes et al., 2006: 33 (distr.); Monné \& Hovore, 2006: 209 (checklist).
Acanthoderes (Psapharochrus) albomaculatus Fuchs, 1963: 10; Gilmour, 1965: 615 (cat.). Syn. nov.

Acanthoderes albomaculata; Monné, 1994: 57 (cat.); Monné \& Giesbert, 1994: 229 (checklist).

Psapharochrus albomaculatus; Monné, 2005: 200 (cat.); Monné \& Monné, 2006: 42; Wappes et al., 2006: 33 (distr.); Monné, 2019: 289 (cat.).

Acanthoderes griseomaculata Zajciw, 1971: 306; Julio et al., 2000: 30 (holotype). Syn. nov.

Acanthoderes (Psapharochrus) griseomaculata; Monné, 1994: 61 (cat.); Monné \& Giesbert, 1994: 230 (checklist).

Psapharochrus griseomaculatus; Monné, 2005: 204 (cat.); Monné et al., 2012: 32 (distr.); Monné \& Chaboo, 2015: 90 (distr.); Monné \& Monné, 2016: 57 (holotype); Monné, 2019: 295 (cat.).

Bates (1861) described Acanthoderes alboniger (see photograph of the holotype at Bezark, 2019) based on a single female from Brazil (Pará). The holotype, as well as a series of specimens from Brazil (Amazonas), has the elytral apex covered with light yellowish-brown pubescence (but not obscuring punctures). Later, Fuchs (1963) described Acanthoderes (Psapharochrus) albomaculatus (see photograph of the holotype at Bezark, 2019) based on a single female from Bolivia and reported (translated): "A very excellent species, with a certain similarity to A. laetifica Bat. According to the description, the new species is related to $A$. albonigra Bat., unknown to me, from which it differs by the blunt lateral tubercles of the prothorax and by drawing of the elytra." However, although the elytral pubescent pattern is somewhat different in the holotypes of $A$. albonigra and A. albomaculata (Acanthoderes is feminine gender, and both names were originally wrongly utilized), the lateral tubercles of the prothorax are identical in both specimens. Bates (1861) incorrectly recorded them as acute, suggesting an apex much narrower than they really are in the species. Finally, Zajciw (1971) described Acanthoderes griseomaculata (see photograph of the holotype at Bezark, 2019) based on a single male from Peru but did not provide any comparison with other species.

Symperasmus alboniger has a noticeable variation of the elytral pubescent pattern color, as it can be yellow, partially yellow and partially pale-yellow, pale-yellow, partially pale-yellow and partially white, or white. Also, the centrodorsal pubescent macula of the elytra may be entire or fragmented, and the anterolateral pubescent spots may be small or large, fused or not with the centrodorsal macula. Furthermore, the apical elytral pubescence is also noticeably variable (Figs. 27-34). The specimens examined from Brazil have the elytral pubescence of the apex as in the holotypes of $A$. albonigra and $A$. albomaculata, while the specimens from Bolivia also have this area as in those holotypes as well as in the holotype of $A$. griseomaculata but with an intermediate pattern. Accordingly, we do not find a reliable feature that allows separation of the three species hence both A. albomaculata and A. griseomaculata are synonymized with S. alboniger. 

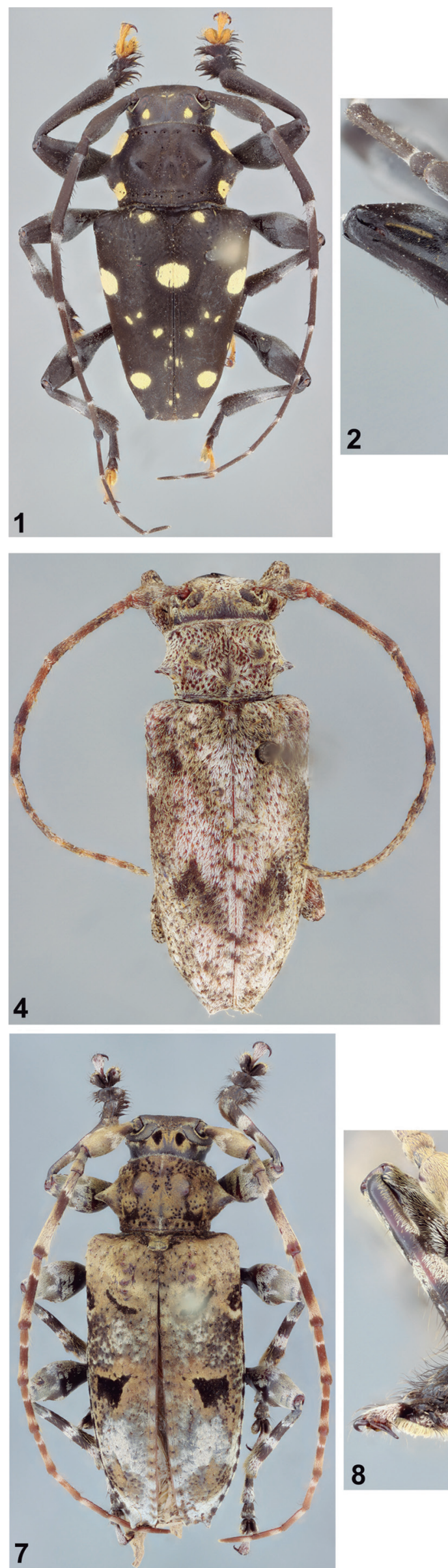

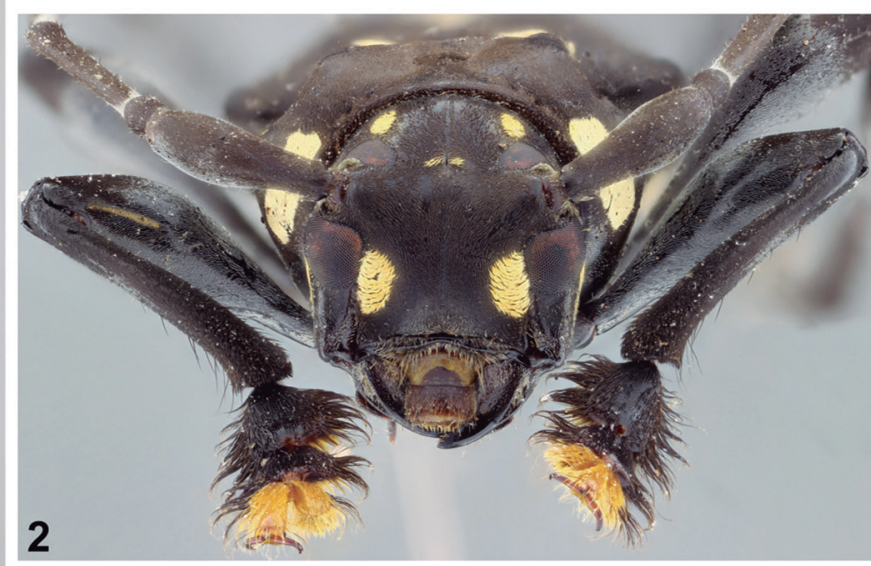

3
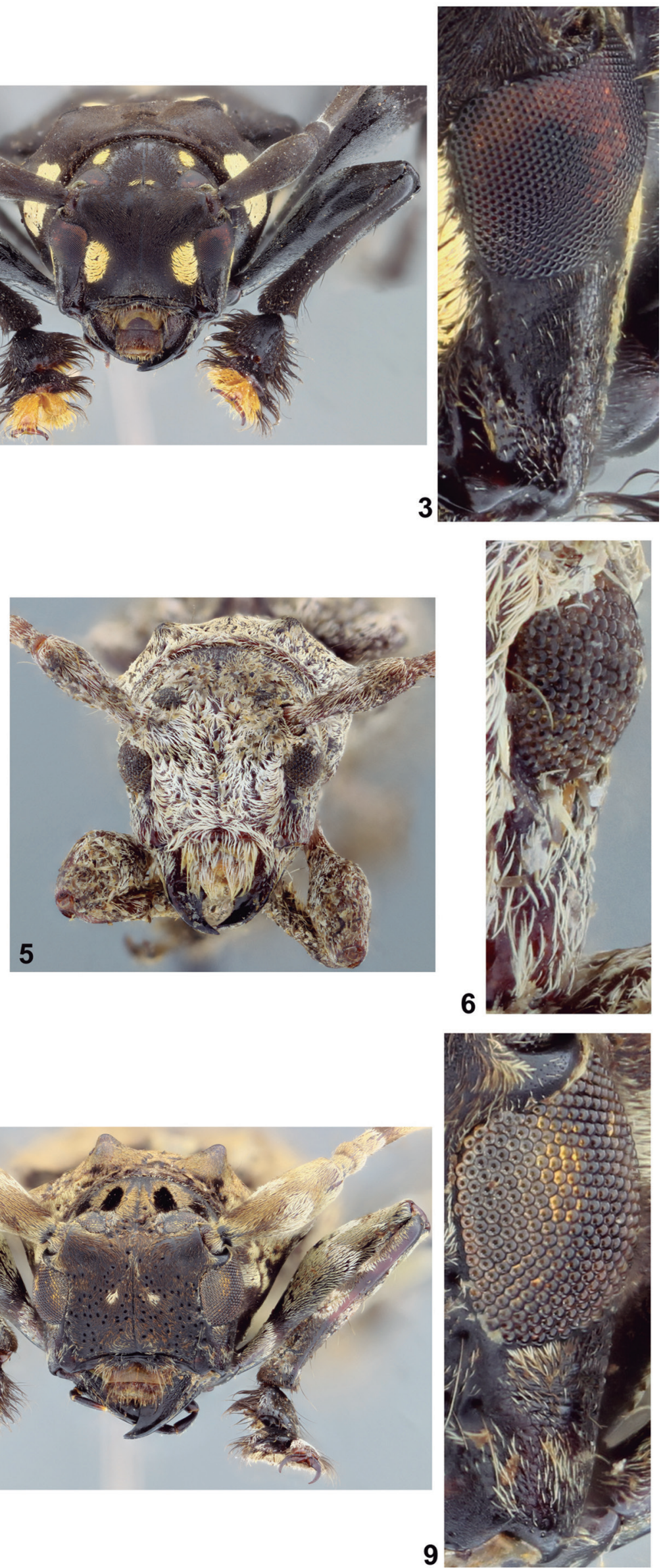

Figures 1-9. (1-3) Acanthoderes daviesii, male. (1) Dorsal habitus. (2) Head, frontal view. (3) Lower eye lobe. (4-6) Aegomorphus modestus, female. (4) Dorsal habitus. (5) Head, frontal view. (6) Lower eye lobe. (7-9) Aegomorphus cylindricus, male. (7) Dorsal habitus. (8) Head, frontal view. (9) Lower eye lobe. 

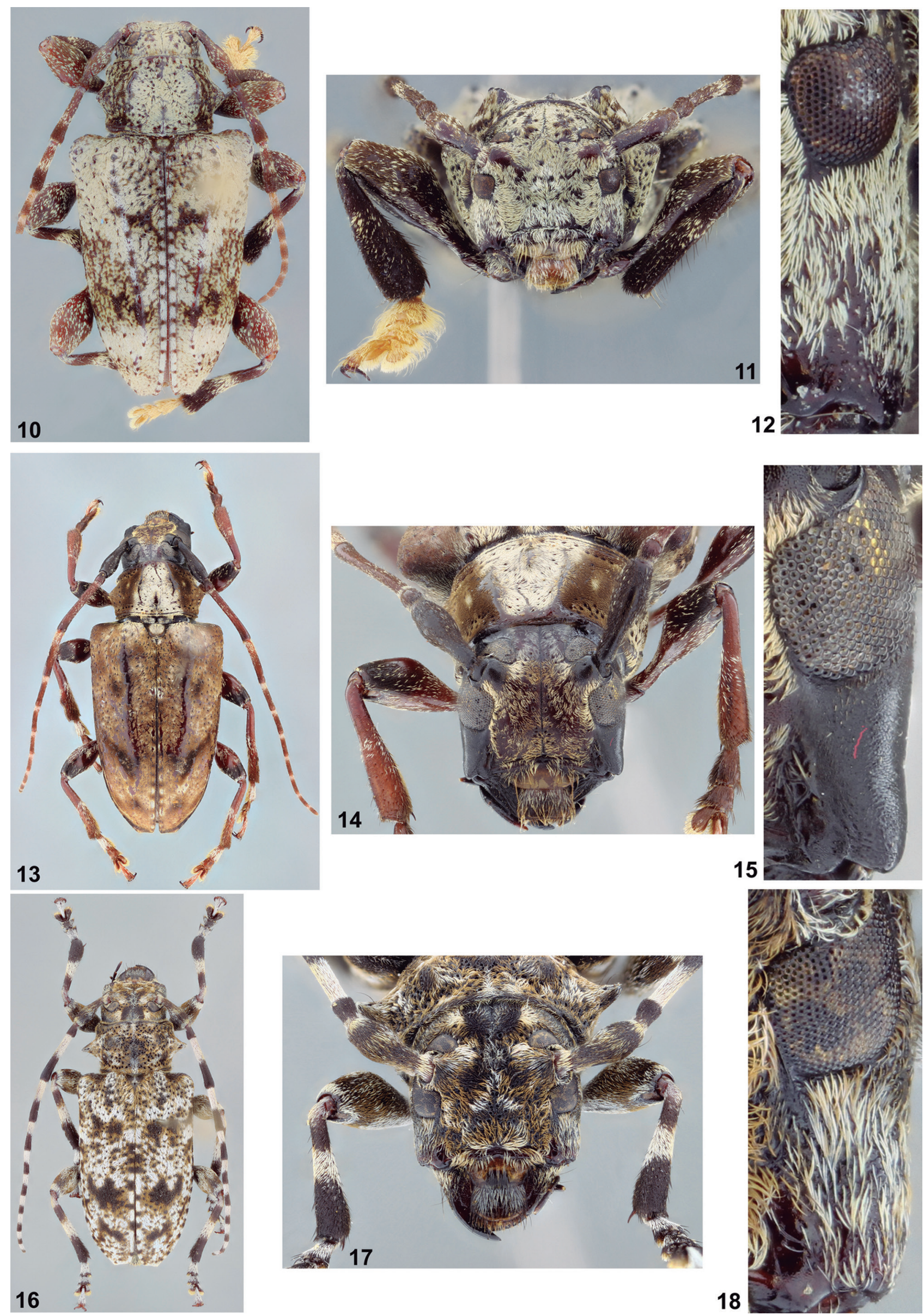

Figures 10-18. (10-12) Scythropopsis albitarsis, male. (10) Dorsal habitus. (11) Head, frontal view. (12) Lower eye lobe. (13-15) Symperasmus thoracicus, female. (13) Dorsal habitus. (14) Head, frontal view. (15) Lower eye lobe. (16-18) Aegomorphus clavipes, female. (16) Dorsal habitus. (17) Head, frontal view. (18) Lower eye lobe. 
The eyes in S. albonigra are not finely granulated, thus, it does not belong to Acanthoderes. Additionally, the pronotum is distinctly depressed centrally, a feature that also supports its placement in Symperasmus, not in Acanthoderes or Psapharochrus (= Aegomorphus) as previously placed.

Material examined (all from MZSP): PERU, Junín: Satipo, 1 female, 18.XII.1937, Paprzycki col.; 1 male, 1938-39, Meskendahl col.; (Sanibeni; 340 m), 1 male, 13.XI.1935, F. Woytjowski col. Huánuco: Tingo Maria (Rio Huallaga), 2 males, X.1960, formerly Dirings collection. BOLIVIA, Beni (new department record): Uyapi (Guanay), 1 male, X-XI.1992, no collector indicated. La Paz (new department record): Ixiamas, 1921-22, M.R. Lopez col. Cochabamba (new department record): "Região de Chaparé", 400 m), 1 female, 05.IX.1956, Zischka col. BRAZIL, Amazonas: São Paulo de Olivença, 1 female, II.1923, S. Klages col.; 1 male, IV.1923, S. Klages col.; 1 male, V.1923, S. Klages col.; (Rio Javari), 1 female, III.1951, formerly Dirings collection; 1 female, VII.1956, formerly Dirings collection; 1 female, X.1960, formerly Dirings collection; 1 female, II.1961, formerly Dirings collection; 3 males, 2 females, X.1961, formerly Dirings collection; 2 males, XI.1961, formerly Dirings collection; 1 female, II.1962, formerly Dirings collection; 1 female, XI.1962, formely Dirings collection; 1 male, 1 female, X.1963, formerly Dirings collection; (Rio Solimões), 1 male, XI.1960, formerly Dirings collection.

Known geographical distribution (Monné, 2019; Tavakilian \& Chevillotte, 2019; new records): Ecuador, Peru, Bolivia (Santa Cruz, Beni, La Paz, Cochabamba), Brazil (Amazonas, Pará).

\section{Scythropopsis Thomson, 1864 resurrection of the original status}

\section{Scythropopsis melanostictica (White, 1855), comb. nov.}

(Figs. 35-39)

Acanthoderes melanosticticus White, 1855: 361.

Psapharochrus melanosticticus; Lacordaire, 1872: 751; Monné, 2005: 208 (cat.); Monné et al., 2010: 246 (distr.); Monné, 2019: 301 (cat.).

Acanthoderes melanosticta; Gemminger, 1873: 3146 (cat., error); Blackwelder, 1946: 611 (cat.); Zajciw \& Seabra, 1968: 72 (distr.); Zajciw, 1969b: 610 (distr.), 1970a: 5 (distr.).

Acanthoderes (Psapharochrus) melanosticta; Aurivillius, 1923: 387 (cat.); Buck, 1959: 604 (distr.); Gilmour, 1965: 615 (cat.); Monné, 1994: 65 (cat.); Mermudes \& Monné, 2001: 331 (error); Monné et al., 2017: 30 (morphology).

Acanthoderes (Psapharochrus) melanostictus; Monné \& Giesbert, 1994: 231 (checklist).

Pteridotelus contaminatus Thomson, 1865: 544; Gemminger, 1873: 3144 (cat.); Thomson, 1878: 15 (type); Aurivillius, 1923: 383 (cat.); Blackwelder,
1946: 610 (checklist); Gilmour, 1965: 611 (cat.); Monné, 1994: 53 (cat.); Monné \& Giesbert, 1994: 237 (checklist); Monné, 2005: 215 (cat.); Monné \& Hovore, 2006: 211 (checklist); Monné, 2019: 308. Syn. nov.

Audinet-Serville (1835) included some species in his new genus Acanthoderes which indicated it was masculine gender (Acanthoderes varius (Fabricius, 1787), and Acanthoderes griseus (Fabricius, 1792)). However, it is actually feminine gender, as previously correctly indicated by Gemminger (1873) and Blackwelder (1946). Gemminger (1873) corrected the gender in only part of the species neglecting to do so for Acanthoderes melanosticticus.

Lacordaire (1872) transferred A. melanosticticus to Psapharochrus Thomson, 1864. As Aurivillius (1923) considered Psapharochrus a subgenus of Acanthoderes, A. melanosticticus was mentioned in this subgenus until recently by nearly all authors, even after Psapharochrus had been considered a distinct genus. In Acanthoderes melanostictica the size of the ommatidia is very small (Figs. 37-38) and the elytra have distinct carina (Santos-Silva \& Nascimento, 2018), hence it belongs to Scythropopsis Thomson, 1864. It also has the protibiae distinctly widened toward apex (Fig. 39), as in the type species of the genus.

Thomson (1865) described two species, in different genera, with the same name: Psapharochrus contaminatus (Fig. 40), and Pteridotelus contaminatus (Fig. 36). Monné \& Giesbert (1992) synonymized Psapharochrus contaminatus with Acanthoderes melanostictus [sic]: "Acanthoderes melanostictus White, 1855: 361/ Acanmoderes [sic] contaminatus Thomson, 1865: 543, new synonymy." However, Psapharochrus contaminatus is not equal to Scythropopsis melanostictica (Fig. 35), rather it is Pteridotelus contaminatus that is the true synonym of the latter.

Material examined (all from MZSP): BRAZIL, Minas Gerais (new state record): Poços de Caldas, 1 female, 11.XI.1954, J.J. Ferraciolli col.; Passa Quatro, 1 female, 14.XI.1916, Zikán col.; (Fazenda dos Campos), 1 male, 30.XII.1917, Zikán col. São Paulo: São Paulo, 1 female, 05.XII.1914, collector illegible; 1 female, 1915, no collector indicated; (Ipiranga), 1 male, 2 females, no date and collector indicated; 1 female, 25.I.1957, collector illegible; (Jabaquara), 1 female, 13.II.1974, L.R. Fontes col.; Campinas, 1 female, XI.1919, collector illegible. Paraná: Guarapuava, 1 female, III.1953, H. Schneider col.; 1 female, I.1960, H. Schneider col.; Ponta Grossa, 1 female, XII.1938, Camargo col.; 1 male, 1941, Machado col.; Rio Negro, 1 female, 07.I.1924, no collector indicated; 1 male, 22.XII.1924, no collector indicated; 1 female, I.1926, no collector indicated; 1 female, 09.III.1927, no collector indicated; Curitiba, 1 male, 05.II.1936, no collector indicated. Santa Catarina: São Bento do Sul, 1 male, XI.1924, A. Maller col.; 1 female, II.1950, formerly Dirings col.; 1 male, II.1952, formerly Dirings col.; 2 females, II.1960, formerly Dirings col.; (Rio Vermelho), 1 male, XII.1949, formerly Dirings col.; 2 females, I.1950, formerly Dirings col.; 1 male, I.1952, formerly Dirings col.; 1 male, II.1952, 
formerly Dirings col.; 1 female, X.1952, formerly Dirings col.; 1 male, XII.1952, formerly Dirings col.; 1 male, I.1958, formerly Dirings col.; 6 males, 4 females, III.1960, formerly Dirings col.; 2 females, I.1961, formerly Dirings col.; 1 female, III.1961, formerly Dirings col.; 1 female, I.1962, formerly Dirings col.; Timbó, 4 males, 3 females, X.1958, formerly Dirings col.

Known geographical distribution (Monné, 2019; Tavakilian \& Chevillotte, 2019; new record): Brazil (Minas Gerais, Espírito Santo, Rio de Janeiro, São Paulo, Paraná, Santa Catarina, Rio Grande do Sul).

\section{Scythropopsis lacrymans (Thomson, 1865), comb. nov.}

(Fig. 42)

Pteridotelus lacrymans Thomson, 1865: 544; Gemminger, 1873: 3145 (cat.); Thomson, 1878: 15 (type).

Acanthoderes lacrymans; Bates, 1880: 140; Blackwelder, 1946: 610 (checklist); Ordóñez-Reséndiz \& MartínezRamos, 2017: 828 (distr.).

Acanthoderes (Psapharochrus) lacrymans; Aurivillius, 1923: 386 (cat.); Gilmour, 1965: 613 (cat.); Monné, 2005: 164 (cat.).

Pteridotelus lachrymosus; Bates, 1880: pl. 11, fig. 6 (error). Acanthoderes lachrymans; Chemsak et al., 1992: 130 (checklist); Noguera \& Chemsak, 1996: 406 (distr.).

Acanthoderes (Pardalisia) lacrymans; Monné, 1994: 70 (cat.); Monné \& Giesbert, 1994: 229 (checklist); VargasCardoso et al., 2018: 96 (hosts); Monné, 2019: 225 (cat.).

Thomson (1865) described Pteridotelus lacrymans without explaining its inclusion in the genus. Since the main feature of Pteridotelus (last antennal segments distinctly widened), is not present in this species it is incorrect to maintain it in the genus. The species Pteridotelus lacrymans appears in Monné \& Giesbert (1994), and Monné (1994) as an Acanthoderes, without explanation in either reference. Factually, Pteridotelus lacrymans cannot be placed in Acanthoderes (Pardalisia), because the antennae are distinctly longer, with distinct ventral pubescence, clearly forming tufts in antennomeres III and IV (distinctly shorter and glabrous in $A$. (P.) funeraria Bates, 1861, elytra carinate toward distal area (not so in A. (P.) funeraria). Due to the antennal setae Pteridotelus lacrymans also has affinities with Tetrasarus Bates, 1880. However, Tetrasarus is another problematic genus with species assigned to but not belonging to it. The presence of a dense tuft of long setae on the apex of antennomeres III and IV is a definitive character of Tetrasarus and is lacking in P. lacrymans. Although Pteridotelus lacrymans differs somewhat in general appearance to other Scythropopsis species it is provisionally placed in the genus because of the common characters previously commented on.

Material examined: MEXICO, Morelos Cuernavaca, 1 male, no date indicated, Martins col. (MZSP).
Known geographical distribution (Monné, 2019; Tavakilian \& Chevillotte, 2019; new record): Mexico (Oaxaca, Puebla, Guerrero, Morelos).

\section{Scythropopsis nigritarsis (White, 1855), comb. nov.} (Figs. 43-54)

Acanthoderes nigritarsis White, 1855: 363; Gemminger, 1873: 3146 (cat.); Bates, 1880: 141 (distr.); Gahan, 1892: 264 (syn.); Blackwelder, 1946: 611 (checklist); Chemsak et al., 1992: 130 (cat.); Noguera \& Chemsak, 1996: 406 (cat.); Chemsak \& Hovore, 2002b: 11.

Acanthoderes (Psapharochrus) nigritarsis; Aurivillius, 1923: 387 (cat.); Gilmour, 1965: 613 (cat.); Monné \& Giesbert, 1994: 231 (checklist); Monné, 1994: 231 (cat.).

Psapharochrus nigritarsis; Turnbow et al., 2003: 29 (distr.); Monné, 2005: 209 (cat.); Hovore, 2006: 376 (distr.); Swift et al., 2010: 46 (distr.); Monné, 2019: 302 (cat.). Acanthoderes sylvanus Bates, 1880: 141, 1885: 378. Acanthoderes sylvana; Lameere, 1883: 62 (checklist).

Description: Female (Figs. 48-52): Integument black, slightly more dark brown on some areas.

Head: Frons, vertex, and area behind eyes with dense, white, yellowish-brown, and pale-yellow pubescence mixed; with sparse, long, erect dark setae close to eyes. Genae with dense pubescence as on dorsal surface of head close to eye, narrow area close to frons glabrous, distinctly sparser on wide remaining surface, with a few long, erect dark setae interspersed. Postclypeus with dense, long white, yellowish-brown, and pale-yellow pubescence intermixed, with sparse, long, erect dark setae interspersed, central area and sides glabrous. Posterior $2 / 3$ of labrum coplanar with anteclypeus, inclined at anterior third; with dense white, yellowish-brown, and pale-yellow pubescence intermixed on sides of posterior $2 / 3$ (whiter and shorter toward central area), distinctly sparser centrally, sparse on inclined area, especially centrally, and with fringe of yellowish-brown setae at anterior margin; with transverse, sparse row of long, erect, dark setae centrally. Gulamentum slightly convex, posterior $2 / 3$ glabrous, depressed, finely punctate, anterior third with short yellowish-brown pubescence not obscuring integument. Distance between upper eye lobes 0.62 times length of scape; in frontal view, distance between lower eye lobes 0.94 times length of scape. Antennae 1.2 times elytral length, reaching posterior seventh of elytra. Scape clavate, flattened dorsally at basal third; with brown pubescence not obscuring integument, with short, moderately abundant white pubescence interspersed on posterior $2 / 3$, except narrow posterior area with dense white pubescence; with a few long, erect dark setae on posterior region of ventral surface. Antennomeres with basal white pubescent ring, gradually narrower toward posterior segments (pubescence sparser on III), and remaining surface with brown pubescence not obscuring integument; pedicel and antennomeres III-VI with sparse, 

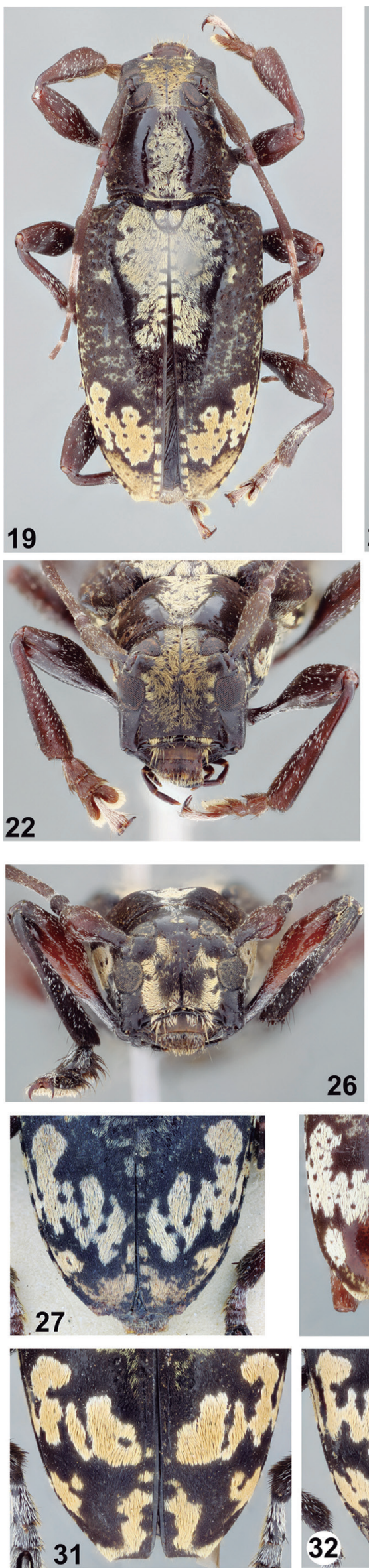
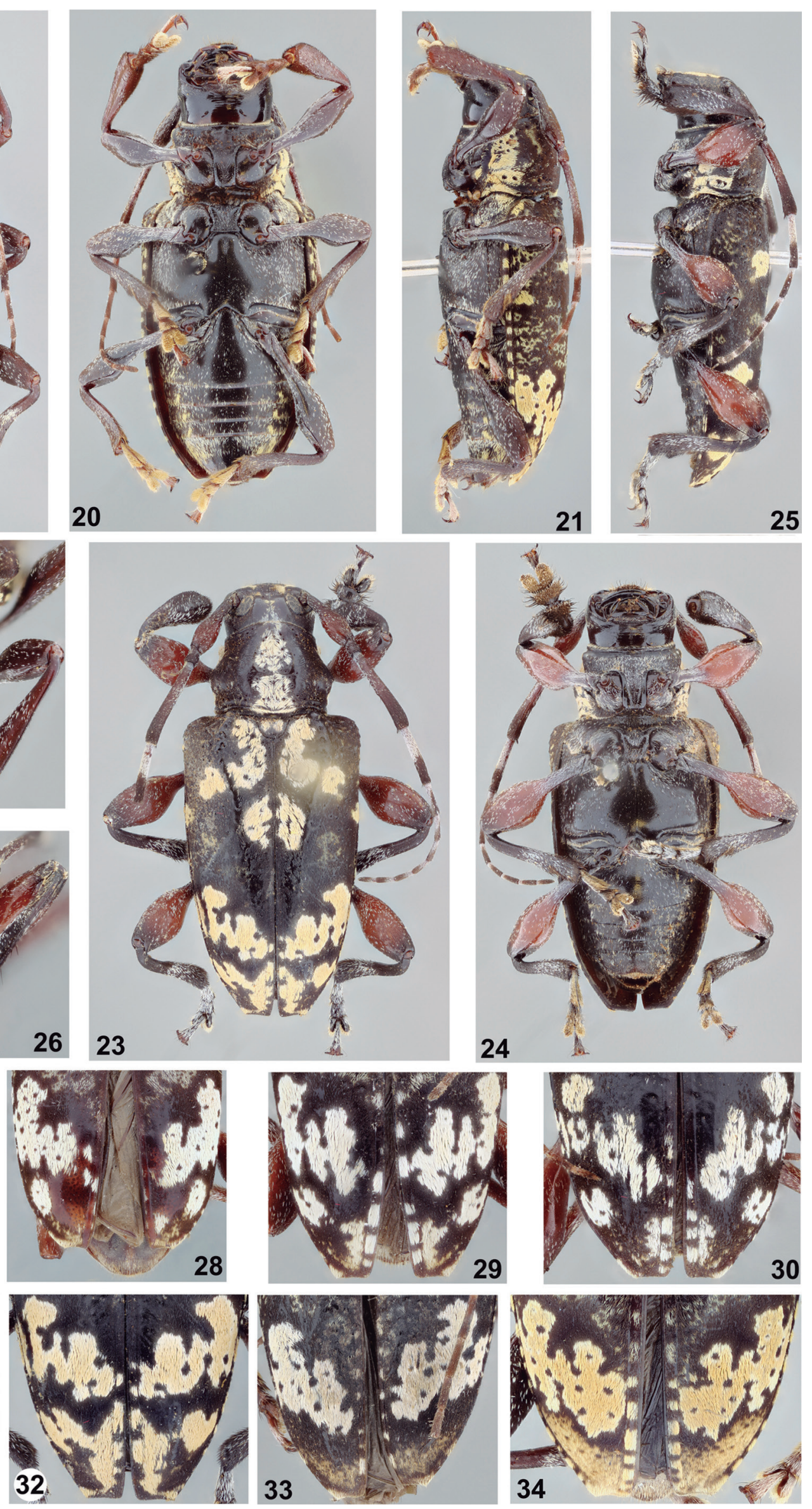

Figures 19-34. Symperasmus alboniger. (19-22) Male from Brazil (Amazonas, Benjamin Constant). (19) Dorsal habitus. (20) Ventral habitus. (21) Lateral habitus. (22) Head, frontal view. (23-26) Male from Peru (Huánuco, Tingo Maria). (23) Dorsal habitus. (24) Ventral habitus. (25) Lateral habitus. (26) Head, frontal view. (27-34) Elytral apex. (27) Female, Bolivia. (28) Female, Bolivia. (29) Female, Peru. (30) Male, Peru. (31) Male, Peru. (32) Male, Peru. (33) Male, Bolivia. (34) Male, Brazil. 

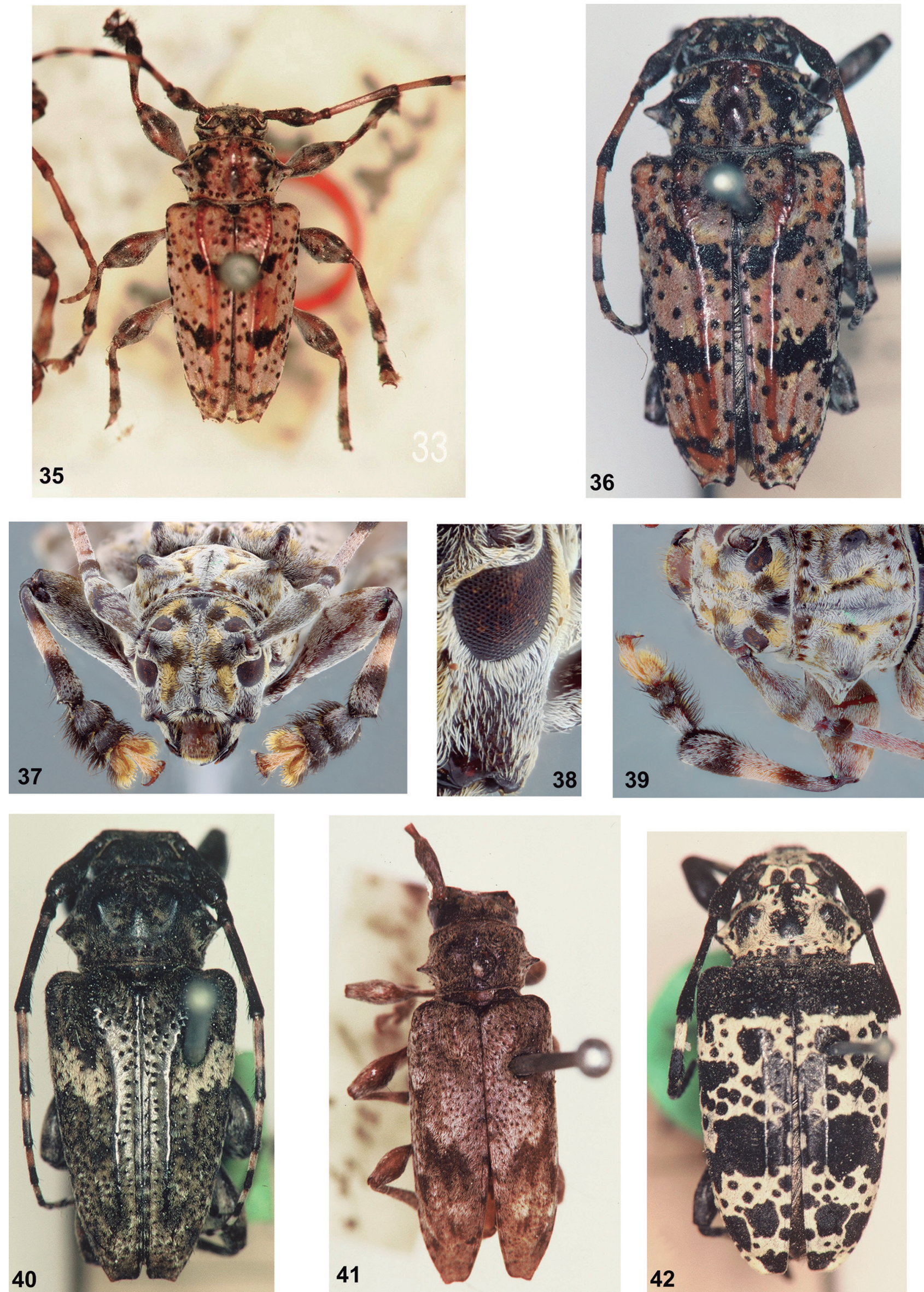

Figures 35-42. (35-39) Acanthoderes melanosticticus, (35) Syntype, dorsal view. (36) Pteridotelus contaminatus, holotype, dorsal habitus. (37) Male from Brazil (Santa Catarina), head, frontal view. (38) Idem, lower eye lobe. (39) Idem, protibia. (40) Psapharochrus contaminatus, holotype male, dorsal habitus. (41) Lamia modesta, holotype, dorsal habitus. (43) Pteridotelus lacrymans, holotype, dorsal habitus. 
long, erect dark setae ventrally (gradually shorter, sparser toward VI). Antennal formula (ratio) based on length of antennomere III: scape $=0.80$; pedicel $=0.23$; IV $=0.77$; $\mathrm{V}=0.46 ; \mathrm{VI}=0.36 ; \mathrm{VII}=0.35 ; \mathrm{VIII}=0.27 ; \mathrm{IX}=0.23 ; \mathrm{X}=0.19$; $\mathrm{XI}=0.19$

Thorax: Lateral tubercle of prothorax large, conical, slightly curved upward, with apex blunt. Pronotum with large, wide tubercle on each side, gradually elevated from posterior quarter toward anterior quarter, with more elevated area slightly bifid at top; with narrow, carina-shaped tubercle centrally, from posterior sulcus to anterior margin, gradually widened toward posterior sulcus; posterior sulcus well-marked; coarsely, sparsely punctate between tubercles, forming transverse row in posterior sulcus, and a few coarse punctures on dorsal surface of lateral tubercles of prothorax; with dense, white, yellowish-brown, and pale-yellow pubescence intermixed, with a few long, erect dark setae interspersed on sides of posterior area, greenish-brown pubescent band adjacent to outer side of lateral tubercles of pronotum, widened anteriorly and posteriorly, anterior $3 / 4$ of central tubercle glabrous, anterior apex of lateral tubercles of pronotum nearly glabrous; posterior fourth with white pubescent band centrally. Sides of prothorax coarsely, sparsely punctate; with dense, white, yellowish-brown, and pale-yellow pubescence intermixed. Prosternum with white, yellowish-brown, and pale-yellow pubescence intermixed, denser on some areas. Prosternal process 0.75 times width of procoxal cavity, coarsely rugose-punctate, longitudinally sulcate centrally, with apex strongly emarginate; pubescence with same color as on prosternum, distinctly sparser toward apex. Ventral surface of mesothorax with dense, white, yellowish-brown, and pale-yellow pubescence intermixed laterally, yellowish-brown centrally. Mesoventral process 1.5 times width of mesocoxal cavity, with one distinct tubercle each side of anterior area; with white, yellowish-brown, and pale-yellow pubescence intermixed, not obscuring integument. Ventral surface of metathorax with dense, white, yellowish-brown, and pale-yellow pubescence intermixed, sparser centrally. Scutellum with dense yellowish-brown pubescence on anterocentral area, with white pubescence interspersed, narrow white pubescent band on central area of posterior third, and brown pubescence on remaining surface. Elytra: Humeri somewhat projected forward; with elevated centrobasal crest covered with small tubercles between humeri and scutellum, and distinct carina from apex of centrobasal crest to near apex; posterior margin concave, with outer angle distinctly triangularly projected; pubescence dense, mostly white, yellowish-brown, and pale-yellow pubescence intermixed, with dense, slightly oblique, wide white pubescent band laterally on anterior third, small greenish-brown spots surrounding punctures, and irregular areas with greenish-brown pubescence; with sparse, moderately long, erect dark setae throughout. Legs: Femora with dense, white, yellowish-brown, and pale-yellow pubescence intermixed. Tibiae with moderately dense, white, yellowish-brown, and pale-yellow pubescence intermixed on dorsal and lateral sides of basal area, and wide central area (this later area somewhat projected toward apex along outer surface), with white pubescence on ventral surface of basal area and dorsal surface of apex, and brownish pubescence on remaining surface, not obscuring integument; with long, erect, sparse dark setae. Tarsomeres I and V with mostly white pubescence dorsally, and remaining segments with brownish pubescence not obscuring integument.

Abdomen: Ventrites with white, yellowish-brown, and pale-yellow pubescence intermixed, sparser on wide central area of $\mathrm{V}$; apex of ventrite $\mathrm{V}$ nearly truncate.

Dimensions (mm): Total length, 16.7; prothoracic length, 3.2; anterior prothoracic width, 4.2; posterior prothoracic width, 4.4; maximum prothoracic width, 5.9; humeral width, 7.2; elytral length, 11.9 .

Material examined: MEXICO, Chiapas (new state record): Reserva Biosfera El Triunfo, $15^{\circ} 39^{\prime} \mathrm{N}, 92^{\circ} 49^{\prime} \mathrm{W}$, 1 female, 15.XI.2001, C.W. O'Brien col. (FWSC). Oaxaca: MX175, 5 km N Portillo de Rayo, 2 males, 20.X.2005, F. Skillman \& B. Eya col. (FWSC; MZSP).

Known geographical distribution (Monné, 2019; Tavakilian \& Chevillotte, 2019; new record): Mexico (Oaxaca, Chiapas), Guatemala, Honduras, Costa Rica.

Remarks: The outer angle of the elytral apex in the female examined is more triangularly projected than in the two males examined. However, based on the study of other species of the genus, as well as similar genera, this feature is considered a variation. The elytral pubescence, in S. nigritarsis varies widely as it does in other species of the genus.

The finely granulate eyes and distinct elytral carina observed in photographs of the holotype and the other material examined ensure us that the species belongs to Scythropopsis.

\section{Scythropopsis sallei (Thomson, 1865), comb. nov. (Fig. 55)}

Psapharochrus sallei Thomson, 1865: 543, 1878: 15 (type); Monné, 2005: 212 (cat.), 2019: 305 (cat.).

Psapharochrus saillei (error); Lacordaire, 1872: 751.

Acanthoderes sallaei (error); Bates, 1880: 141 (distr.); Noguera \& Chemsak, 1996: 406 (checklist).

Acanthoderes (Psapharochrus) sallei; Aurivillius, 1923: 388 (cat.); Gilmour, 1965: 613 (cat.); Monné \& Giesbert, 1994: 231 (checklist); Monné, 1994: 67 (cat).

Acanthoderes sallei; Blackwelder, 1946: 611 (checklist); Zajciw, 1970b: 187; Chemsak et al., 1992: 130 (checklist).

Thomson (1865) described the species from Mexico, without a specific locality. Subsequently Bates (1880) provided: Córdova (= Córdoba) in the Mexican state of 
Veracruz as a collection locality. Noguera \& Chemsak (1996) reiterated the Bates (1880) information.

Although the outer angle of the elytral apex is distinctly projected on the holotype of Psapharochrus sallei, and not so in the holotypes of Acanthoderes nigritarsis and Acanthoderes sylvanus, it is still possible that they belong to the same species. For example, the female of Scythropopsis nigritarsis examined by us has the elytral apex intermediate between the three holotypes. This kind of variation is not unusual in Acanthoderini as, for example, in Aegomorphus jaspideus (Germar, 1823) where the outer angle of the elytra is usually distinctly projected but, can also be slightly or even not at all projected.

The finely granulate eyes and distinct elytral carina, as shown in the photograph of the holotype, support the species transference to Scythropopsis.

Known geographical distribution (Monné, 2019; Tavakilian \& Chevillotte, 2019): Mexico (Veracruz).

\section{Scythropopsis cornuta (Bates, 1880), comb. nov. (Figs. 56-61)}

Acanthoderes cornutus Bates, 1880: 142.

Acanthoderes cornuta; Lameere, 1883: 62 (cat.); Blackwelder, 1946: 610 (checklist); Chemsak et al., 1992: 130 (checklist).

Acanthoderes (Psapharochrus) cornuta; Aurivillius, 1923: 386 (cat.); Gilmour, 1965: 614 (cat.); Monné \& Giesbert, 1994: 230 (checklist); Monné, 1994: 60 (cat.). Psapharochrus cornuta; Turnbow et al., 2003: 29 (distr.). Psapharochrus cornutus; Monné, 2005: 203 (cat.); Hovore, 2006: 376 (distr.); Monné, 2019: 293 (cat.).

Description: Male (Figs. 57-61): Integument mostly dark brown, almost black on some areas; anteclypeus, apex of labrum, parts of mouthparts, and apex of palpomeres reddish-brown; antennomeres V-XI with orange ring on basal third; central area of anterior third of elytra with large, triangular reddish-brown macula.

Head: Frons, area between antennal tubercles and beginning of upper eye lobes finely, sparsely punctate; with moderately dense brownish pubescence (more reddish-brown close to eyes and postclypeus), with white pubescence interspersed. Remaining surface of vertex smooth, with dark brown pubescence centrally, partially obscuring integument, and longitudinal yellowish-white pubescent band laterally. Area behind upper eye lobes with sparse fringe of yellowish-white pubescence close to eye, glabrous on narrow sulcate area close to eye, with yellowish-brown pubescence close to sulcate area, nearly glabrous toward prothorax. Area behind lower eye lobes glabrous on sulcus adjacent to eye, with narrow (widened near inferior curvature of eye) yellowish-brown pubescent band close to sulcus (pubescence sparser than behind lower eye lobe), remaining surface glabrous. Genae almost twice length of lower eye lobe; with fringe of yellowish-brown pubescence close to eye, and sparse yellowish-brown pubescence, with white pubescence interspersed on remaining surface, narrow distal area glabrous. Postclypeus coarsely, sparsely punctate on wide central area, smooth laterally; with short, bristly reddish-brown pubescence not obscuring integument on wide central area more so on center of this area, laterally glabrous; with long, sparse, erect dark setae on wide central area. Posterior $2 / 3$ of labrum coplanar with anteclypeus, inclined at anterior third; with yellowish-brown pubescence not obscuring integument, on posterior $2 / 3$, anterior third nearly glabrous, anterior margin with fringe of brown setae (apex of nearly all setae yellowish); with transverse row of long, erect, dark setae near curvature between coplanar and inclined area. Gulamentum glabrous, wide posterior area smooth, except transverse striae on center of anterior region of this area; anterior area depressed, transversely striate, with sparse reddish-brown pubescence close to anterior margin. Distance between upper eye lobes 0.55 times length of scape; in frontal view, distance between lower eye lobes equal to length of scape. Antennae 1.65 times elytral length, reaching elytral apex near apex of antennomere VIII. Scape clavate, distinctly sulcate dorsally at anterior third; dorsally with reddish-brown pubescence except wide transverse white pubescent band centrally, and narrow white pubescent band at apex; remaining surface with white pubescence not obscuring integument. Pedicel with transverse white pubescent band dorsally near base, brown on remaining dorsal surface except yellowish-white on outer side close to apex; ventral and lateral surfaces with white pubescence. Antennomeres III and IV with two white pubescent rings, one basally, another after middle, ventrally fused by longitudinal band; remaining surface with brown pubescence. Antennomeres V-XI with white pubescence on basal half, brown on distal half; distal third of antennomere IX and basal $2 / 3$ of antennomere $X$ with long, erect dark setae. Antennal formula (ratio) based on length of antennomere III: scape $=0.73$; pedicel $=0.29 ; \mathrm{IV}=0.76 ; \mathrm{V}=0.45$; $\mathrm{VI}=0.39 ; \mathrm{VII}=0.35 ; \mathrm{VIII}=0.31 ; \mathrm{IX}=0.27 ; \mathrm{X}=0.21 ; \mathrm{XI}=0.24$.

Thorax: Lateral tubercle of prothorax large, conical. Pronotum with large, nearly conical tubercle each side, with wide, rounded apex; with narrow, carina-shaped tubercle centrally, from posterior sulcus to anterior margin, slightly widened posteriorly; posterior sulcus distinct laterally, nearly indistinct toward center; coarsely, sparsely punctate between tubercles, slightly coarser and more abundant between anterior margin and base of lateral tubercles, and along posterior sulcus, shallower, sparser on lateral tubercles of prothorax; with white, yellowish-brown, and pale-yellow pubescence intermixed, partially obscuring integument in some areas. Sides of prothorax coarsely, sparsely punctate (punctures distinctly coarser close to posterior margin); pubescence as on pronotum. Prosternum with pale-yellow pubescence not obscuring integument. Prosternal process with widest central area about as wide as procoxal cavity; lateral margins sinuous and elevated; central area longitudinally slightly elevated; with sparse pale-yellow pubescence. 

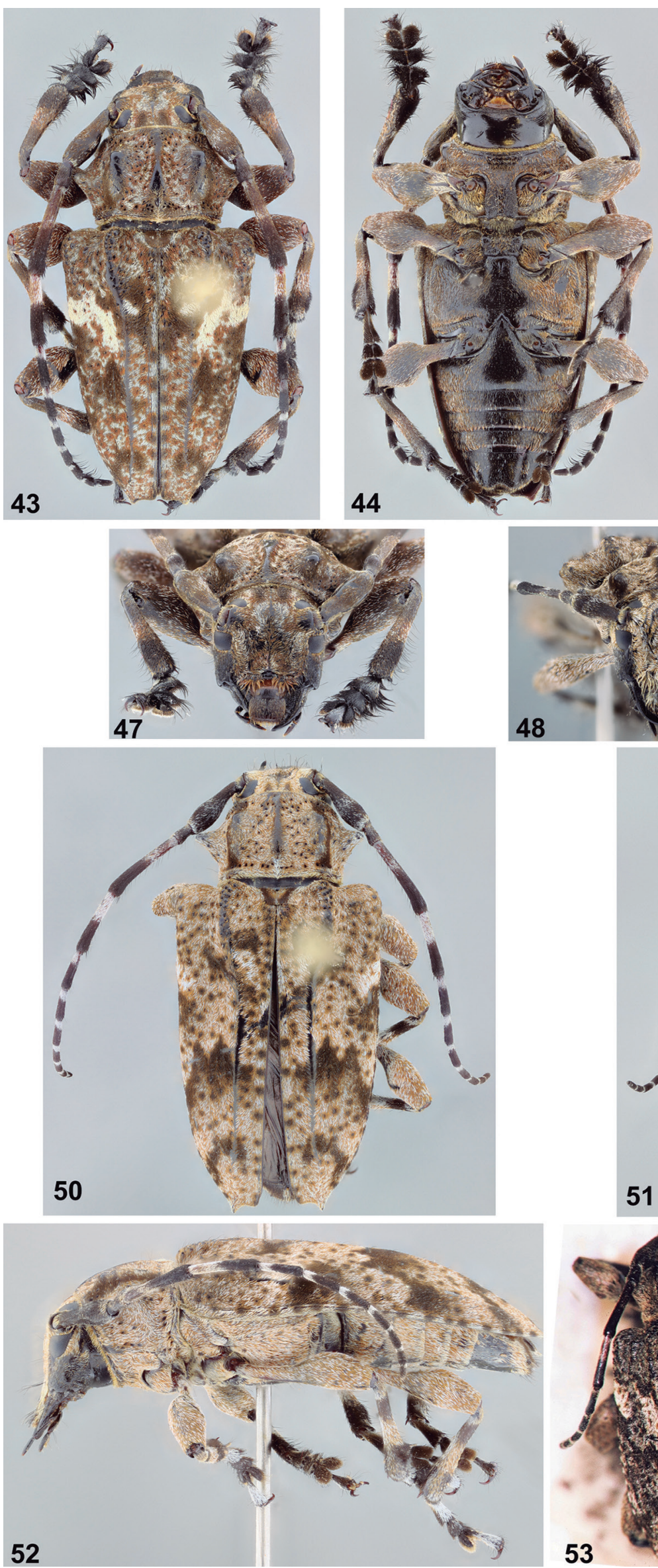
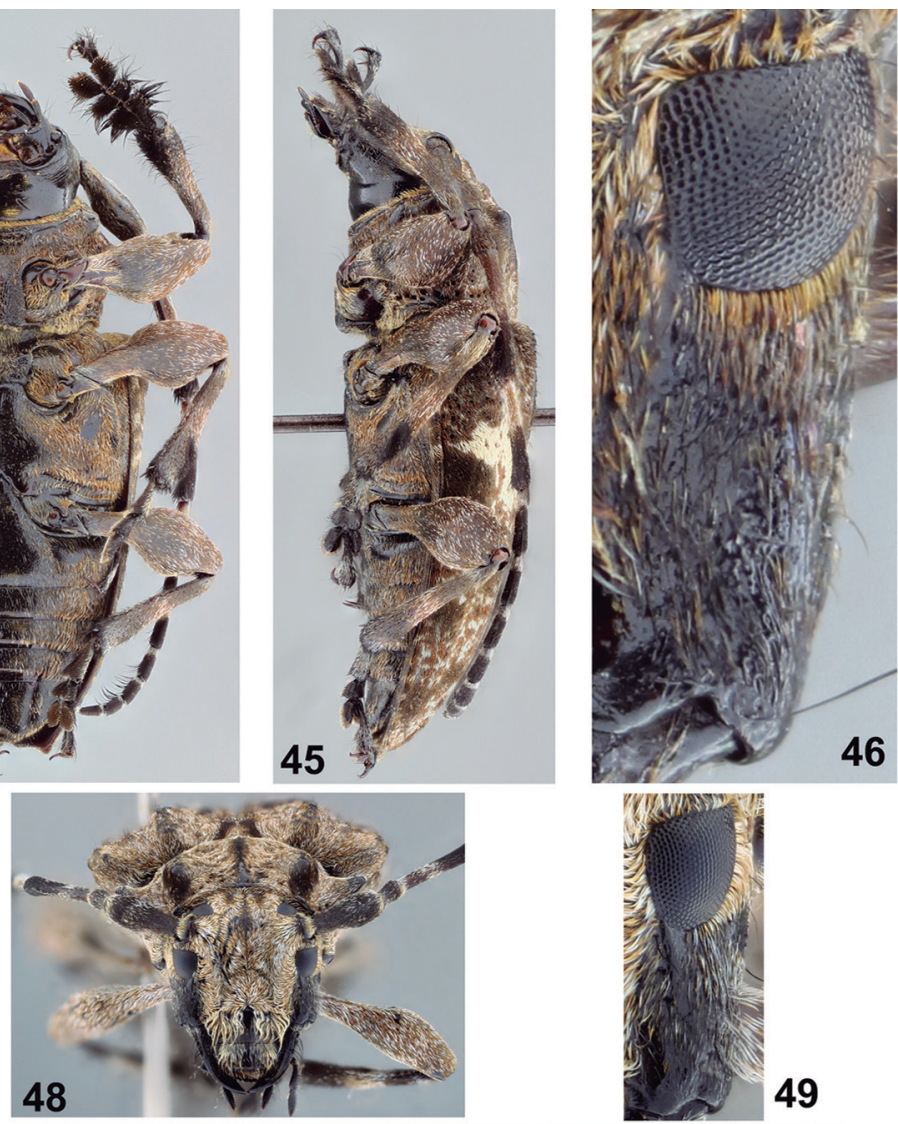

49
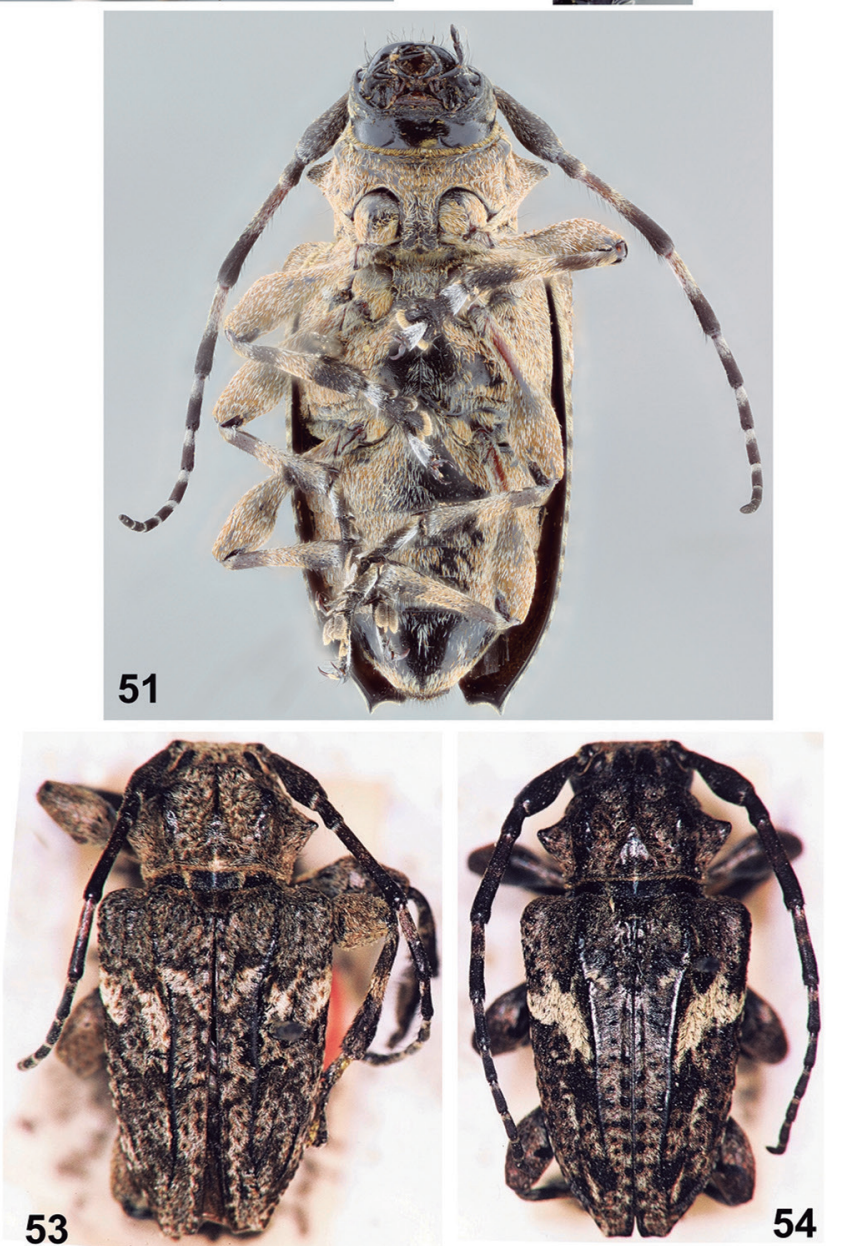

Figures 43-54. Scythropopsis nigritarsis. (43-47) Male. (43) Dorsal habitus. (44) Ventral habitus. (45) Lateral habitus. (46) Lower eye lob. (47) Head, frontal view. (48-52) Female. (48) Head, frontal view. (49) Lower eye lobe. (50) Dorsal habitus. (51) Ventral habitus. (52) Lateral habitus. (53) Holotype male, dorsal habitus. (54) Acanthoderes sylvanus, holotype male, dorsal habitus. 

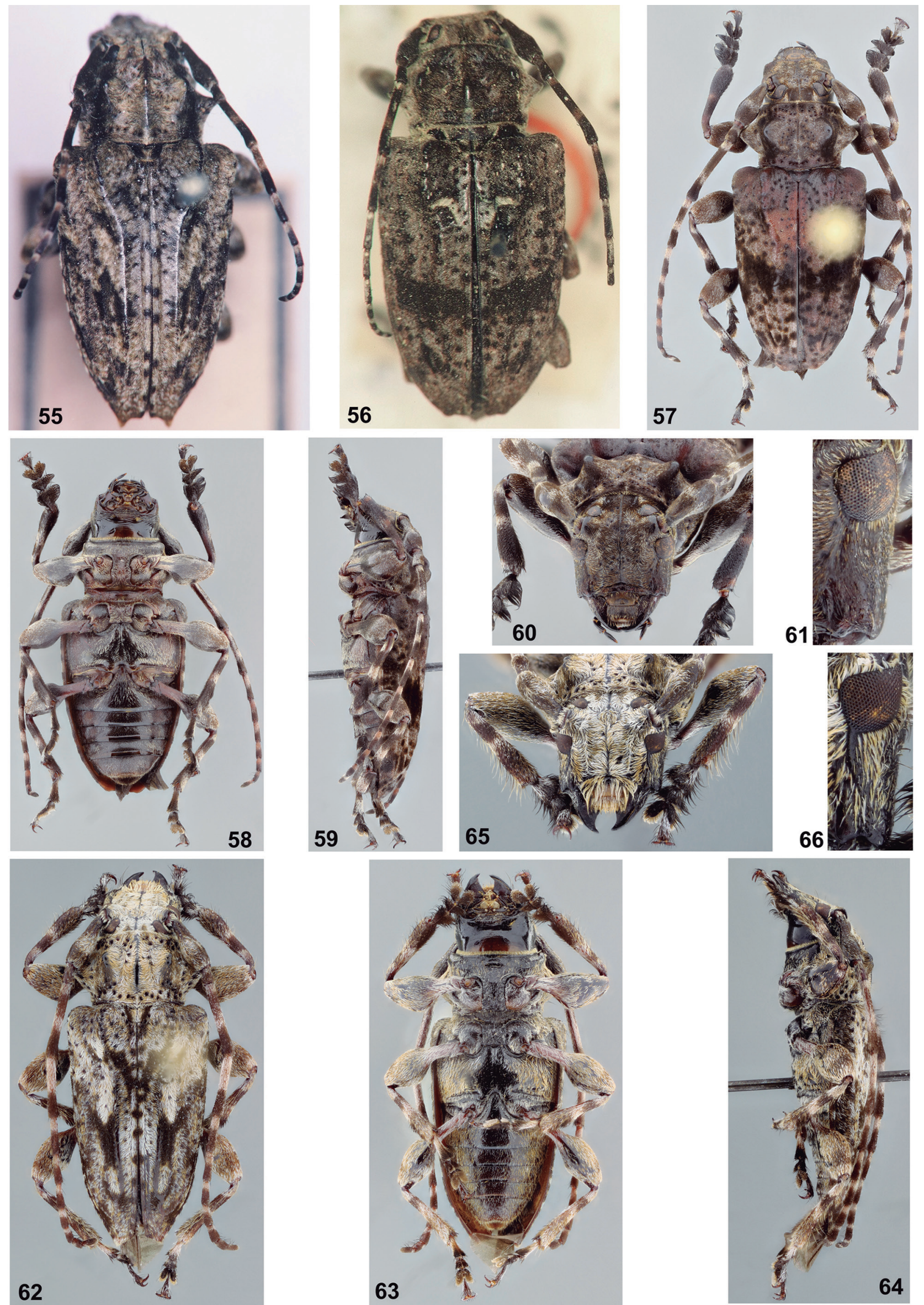

Figures 55-66. (55) Psapharochrus sallei, holotype female, dorsal habitus. (56-61) Scythropopsis cornuta. (56) Holotype female, dorsal habitus. (57) Dorsal habitus, male. (58) Ventral habitus, male. (59) Lateral habitus, male. (60) Head, frontal view, male. (61) Lower eye lobe, male. (62-66) Scythropopsis wappesi, male. (62) Dorsal habitus. (63) Ventral habitus. (64) Lateral habitus. (65) Head, frontal view. (66) Lower eye lobe. 
Ventral surface of meso- and metathorax with pale-yellow pubescence not obscuring integument, sparser on center of meso- and metaventrite. Mesoventral process with apex slightly wider than mesocoxal cavity; with one moderately large tubercle each side of anterior area; lateral margins slightly narrowed centrally, distinctly widened at apex. Scutellum with yellowish-white pubescence not obscuring integument. Elytra: Humeri rounded, somewhat projected forward; with elevated centrobasal crest between humeri and scutellum, nearly conically elevated anteriorly, covered with small tubercles, and distinct carina from apex of centrobasal crest to near apex; with another carina between the crest and humeri; elytral carina fused at their apex; coarsely, sparsely punctate, punctures sparser, shallower toward apex, with basal punctures anteriorly bordered by small tubercle; apex truncate, slightly concave centrally; pubescence mostly yellowish-white, less so between centrobasal crests, except wide, irregular, slightly oblique dark-brown pubescent band about middle (with irregular yellowish-white macula on inclined area), and dark-brown spots surrounding punctures; U-shaped white pubescent band on basal third partially lost in the specimen examined. Legs: Femora with yellowish-white pubescence partially obscuring integument on some areas, with brown pubescent areas interspersed on club. Tibiae with three rings of yellowish-white pubescence, one basally, one centrally, another at apex; remaining surface with brown pubescence. Protarsi with dark-brown pubescence dorsally, with a few whitish setae interspersed on tarsomere I. Tarsomere I of meso- and metatarsi with dense white pubescence on posterior $2 / 3$ of dorsal surface, dark-brown pubescence basally; tarsomeres II-IV with dark-brown pubescence; tarsomere $\mathrm{V}$ with white pubescence not obscuring integument.

Abdomen: Ventrites with yellowish-white pubescence not obscuring integument, sparser centrally, with distal area of ventrites I-IV glabrous; distal margin of ventrite V concave.

Dimensions (mm): Total length, 12.80; prothoracic length, 2.60; anterior prothoracic width, 3.20; posterior prothoracic width, 3.15 ; maximum prothoracic width, 4.55; humeral width, 5.15; elytral length, 8.20.

Material examined: NICARAGUA (new country record): Nueva Segovia: Cerro Jesus $\left(13^{\circ} 58^{\prime} \mathrm{N}, 86^{\circ} 10^{\prime} \mathrm{W}\right.$; 1,100-1,200 m), 1 male, VI-VII.2016, E. van den Berghe col. (ACMT).

Known geographical distribution (Monné, 2019; Tavakilian \& Chevillotte, 2019; new record): Guatemala, Honduras, Nicaragua.

Remarks: Bates (1880) described the species from Guatemala, based on a single female. Subsequently, the species has only been mentioned in catalogs and checklists, except for Turnbow et al. (2003), who provided Honduras as a new country record. Examination of the photograph of the holotype, as well as the male described here, reveals that the eyes are finely granulated, and the elytra distinctly carinate. Accordingly, the species is transferred to Scythropopsis.

\section{Scythropopsis wappesi (Chemsak \& Hovore, 2002), comb. nov. \\ (Figs. 62-66)}

Acanthoderes wappesi Chemsak \& Hovore, 2002b: 7; Monné, 2005: 163 (cat.); Hovore, 2006: 376 (distr.).

Acanthoderes (Acanthoderes) wappesi Monné, 2005: 163 (cat.); Monné \& Hovore, 2006: 203 (checklist).

Psapharochrus wappesi; Tavakilian, 2018: 39 (comb. nov.); Monné, 2019: 307 (cat.).

According to Tavakilian (2018): "The photography of the type available on Bezark's Catalog (2018)... shows clearly that the species described as Acanthoderes wappesi Chemsak \& Hovore, 2002... belongs to the genus Psapharochrus Thomson, 1863 and not to the genus Acanthoderes Audinet-Serville, 1835. This necessary new combination induces a new homonym and the latest species described in honour of James Wappes must be renamed." However, Chemsak \& Hovore (2002b) reported the eyes as being "finely faceted", which was confirmed in the specimen examined by us. As the species also has distinctly elytral carina, it belongs to Scythropopsis and thus negates the need for a replacement name.

Material examined: MEXICO (new country record): Tamaulipas: 10 km E Tula (3900'), 1 male, 10.V.1994, J.E. Wappes col. (ACMT).

Known geographical distribution (Monné, 2019; Tavakilian \& Chevillotte, 2019; new record): Guatemala, Mexico (Tamaulipas).

\section{Scythropopsis barrerai (Chemsak \& Hovore, 2002), comb. nov. (Figs. 67-71)}

Acanthoderes barrerai Chemsak \& Hovore, 2002a: 13. Acanthoderes (Acanthoderes) barrerai Monné, 2005: 160 (cat.); Monné \& Hovore, 2006: 202 (checklist); Monné, 2019: 220 (cat.); Santos-Silva et al., 2018: 205 (distr.).

As in the photograph of the holotype, as well as the female from the MZSP collection, the eyes are finely granulated and the elytra are distinctly carinate, the species is appropriately transferred to Scythropopsis.

Material examined: MEXICO, Veracruz: Los Tuxtlas (900 m), 1 female, 01-15.VI.2016, J.H. Garcia col. (MZSP).

Known geographical distribution (Monné, 2019; Tavakilian \& Chevillotte, 2019): Mexico (Querétaro, Hidalgo, Veracruz). 


\section{Scythropopsis intricata sp. nov. (Figs. 72-76)}

Description: Female: Integument mostly black; mouthparts dark reddish-brown with darkened areas, except palpi of last palpomeres black with yellowish-brown apex.

Head: Frons dense white pubescent with narrow, longitudinal, central glabrous band close to clypeus; with a few long, erect dark setae close to lower eye lobes. Area between antennal tubercles and upper eye lobes, and behind upper eye lobes with dense white pubescence, except moderately narrow, longitudinal, glabrous central band between antennal tubercles and upper eye lobes, orange pubescence interspersed in area adjacent to inner side of upper eye lobes, orange pubescent macula behind beginning of the upper eye lobes, and oblique orange pubescent band each side of median groove between antennal tubercles and upper eye lobes, and triangular glabrous indent on posterior central area; area of vertex and behind upper eye lobes close to prothorax glabrous; with a few long, erect dark setae close to eyes. Area behind lower eye lobes (this area widened toward ventral surface) with dense white pubescence close to wide superior area of eye, with orange pubescence interspersed, orange pubescence on inferior area close to eye, with white pubescence interspersed. Genae slightly shorter than twice length of lower eye lobe; with dense orange pubescence close to eye and white pubescence interspersed, distinctly sparser toward glabrous apex. Postclypeus with dense, long, decumbent white pubescence on wide central area, glabrous laterally; with sparse, long, erect dark setae on pubescent area. Posterior $2 / 3$ of labrum coplanar with anteclypeus, inclined at anterior third; with dense, long, decumbent white pubescence on posterior $2 / 3$, sparser, shorter on anterior third; with fringe of pale-yellow setae in anterior margin; with sparse, long, erect dark setae in central area of posterior $2 / 3$. Gulamentum glabrous except narrow anterior area with yellowish-white pubescence not obscuring integument. Distance between upper eye lobes 0.9 times length of scape; in frontal view, distance between lower eye lobes 1.2 times length of scape. Antennae 1.25 times elytral length, reaching posterior fifth of elytra. Scape clavate, longitudinally sulcate dorsally in basal half; with yellowish brown pubescence partially obscuring integument dorsally and laterally, with white pubescence interspersed, except white distal pubescent ring, which surrounds the entire circumference of the scape; ventral surface with white pubescence not obscuring integument; with a few long, erect dark setae ventrally. Pedicel with abundant white pubescence, except yellowish-brown pubescence on center of dorsal and lateral surfaces; with a few long, erect dark setae ventrally. Antennomere III with abundant white pubescence on wide anterior area, except sparsely pubescent on center of dorsal and lateral surfaces of this area; remaining surface with dark pubescence partially obscuring integument; anterior $3 / 4$ of ventral surface with sparse, long, erect dark setae, becoming noticeable denser, forming distinct tuft on posterior quarter. Antennomere IV with anterior $2 / 3$ densely white pubescent, dark on remaining surface; with long, erect dark setae on ventral surface of posterior third, forming distinct tuft in posterior quarter of antennomere (shorter than in III). Antennomere V with dense white pubescence on basal half, dark on distal half; ventral third of surface with moderately short and abundant, erect dark setae. Remaining antennomeres with basal white pubescent ring, and dark pubescence on remaining surface. Antennal formula (ratio) based on length of antennomere III: scape $=0.75$; pedicel $=0.25$; $\mathrm{IV}=0.75 ; \mathrm{V}=0.42 ; \mathrm{VI}=0.30 ; \mathrm{VII}=0.25 ; \mathrm{VIII}=0.20 ; \mathrm{IX}=0.17$; $\mathrm{X}=0.15 ; \mathrm{XI}=0.20$.

Thorax: Lateral tubercle of prothorax large, conical, slightly curved upward, with blunt apex. Pronotum with large, elevated tubercle on each side, with top truncate and somewhat bifid; with large tubercle centrally, from posterior sulcus to near anterior margin, triangular-shaped posteriorly, carina-shaped anteriorly; slightly well-marked centrally, more distinct laterally; with coarse, sparse punctures, forming transverse row in posterior sulcus; with white and orange pubescence intermixed, denser laterally, with white pubescence prevailing in some areas, orange in others, apex of lateral pronotal tubercles, and parts of central tubercle; with a few long, erect dark setae posteriorly. Sides of prothorax with dense white pubescence, with orange pubescence interspersed on some areas. Prosternum with white pubescence, denser laterally, with orange pubescence interspersed on area under procoxal cavities. Prosternal process about as wide as procoxal cavity, coarsely rugose-punctate, longitudinally sulcate centrally, with apex strongly emarginate; with abundant white pubescence not obscuring integument. Ventral surface of mesothorax with abundant yellowish-white pubescence centrally, not obscuring integument, dense, white pubescence, obscuring integument laterally, except large area of mesanepisternum with orange pubescence interspersed. Mesoventral process slightly wider than mesocoxal cavity, with distinctly, elevated tubercle each side of anterior area; with white pubescence nearly obscuring integument, top of lateral tubercles glabrous. Ventral surface of metathorax with dense yellowish-white pubescence, with orange pubescence interspersed in some areas of sides. Scutellum with white pubescence centrally, orange on sides, margins with white and orange pubescence intermixed. Elytra: Humeri projected slightly forward; with elevated centrobasal crest between humeri and scutellum, covered with small tubercles, and distinct carina from apex of centrobasal crest to near apex; with another slightly distinct basal crest, also between humeri and scutellum but placed more laterally that the former crest, covered with small tubercles (sparser than in the other crest), followed by another carina, fused with the innermost near apex; humeral area with small, sparse tubercles; apex truncated with outer angle triangularly projected; with sparse, erect dark setae throughout; pubescence dense, mostly white with orange pubescent maculae and bands interspersed, except seven, notice- 

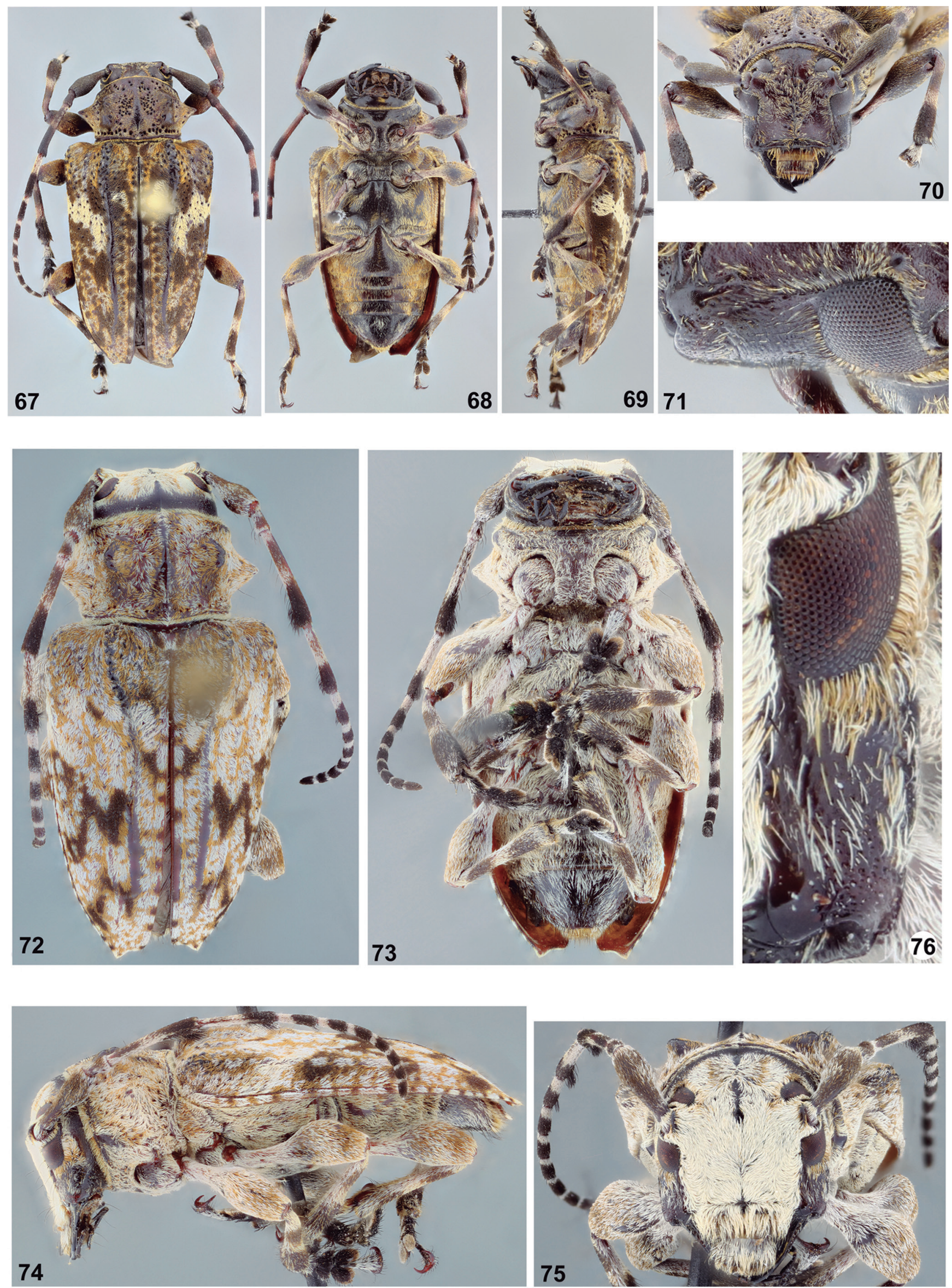

Figures 67-76. (67-71) Scythropopsis barrerai, female. (67) Dorsal habitus. (68) Ventral habitus. (69) Lateral habitus. (70) Head, frontal view. (71) Lower eye lobe. (72-76) Scythropopsis intricata sp. nov. holotype female. (72) Dorsal habitus. (73) Ventral habitus. (74) Lateral habitus. (75) Head, frontal view. (76) Lower eye lobe. 

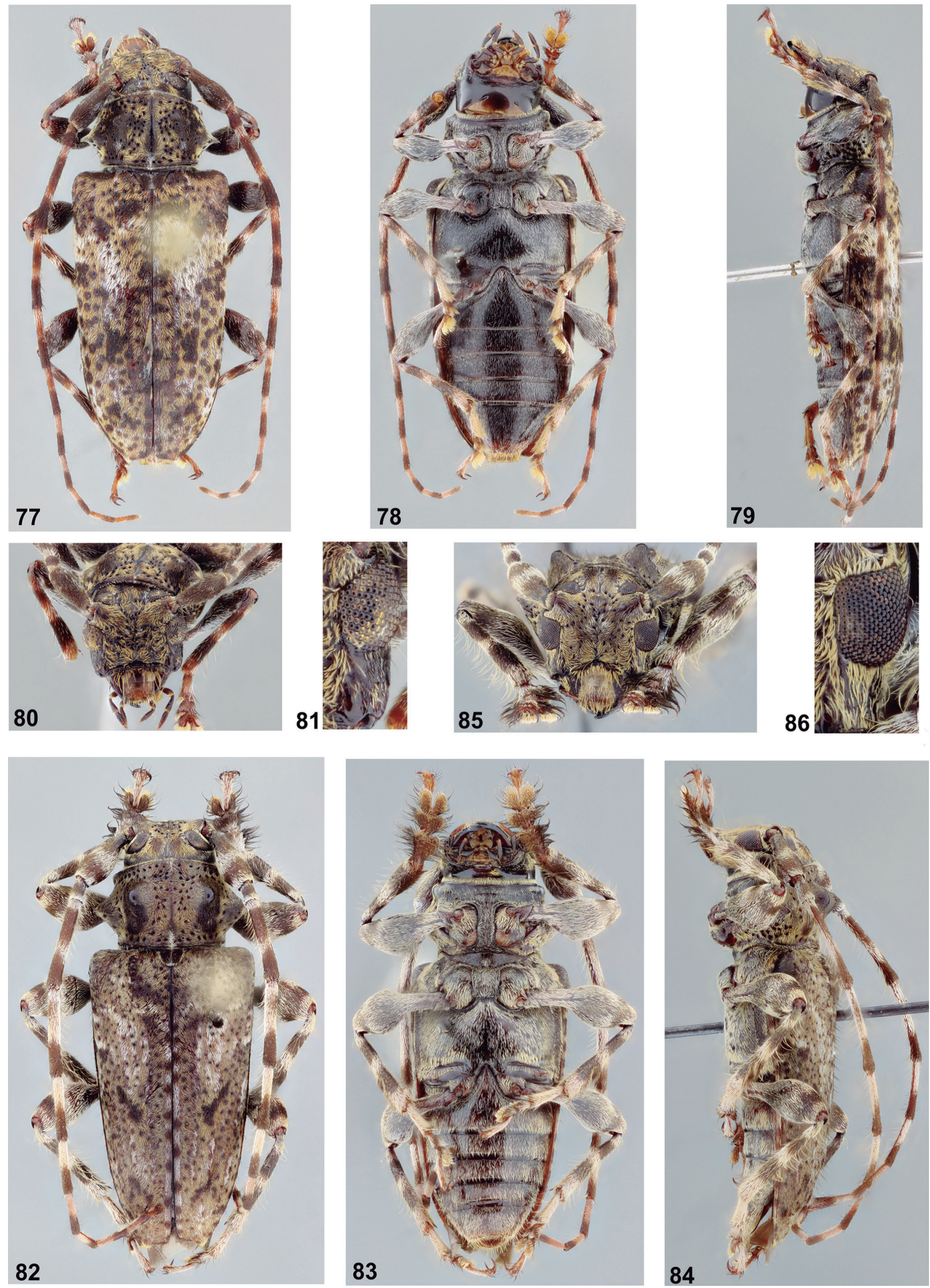

Figures 77-86. (77-81) Aegomorphus ramirezi, male. (77) Dorsal habitus. (78) Ventral habitus. (79) Lateral habitus. (80) Head, frontal view. (81) Lower eye lobe. (82-86) Aegomorphus maccartyi, male. (82) Dorsal habitus. (83) Ventral habitus. (84) Lateral habitus. (85) Head, frontal view. (86) Lower eye lobe. 
able dark-brown pubescent areas: one small, oblique, placed centrally on anterior third; one before middle laterally; one arched before middle close to suture; one zig-zag, large, placed about middle, not reaching suture; one inverted V-shaped dorsally on posterior fifth; another oblique, placed laterally on posterior fifth; sparse small maculae along posterior half of suture and posterior margin. Legs: Femora with dense white pubescence on peduncle and base of club, with white and orange pubescence intermixed on remaining surface. Tibiae with three yellowish-white pubescent rings, one basally, one centrally, another narrower, less conspicuous on apex; remaining surface with dark-brown pubescence; entire surface with short, sparse orange setae interspersed. Tarsomeres I and $\mathrm{V}$ mostly with white pubescence dorsally, and remaining segments with brownish pubescence not obscuring integument.

Abdomen: Ventrites I-IV with yellowish-white pubescence laterally, gradually whiter, sparser toward central area; ventrite $\mathrm{V}$ mostly with white pubescence, distinctly sparser on some large areas, with sparse, long, erect dark setae interspersed posteriorly; apex of ventrite $V$ truncate.

Dimensions (mm): Total length, 12.9; prothoracic length, 2.7; anterior prothoracic width, 4.1; posterior prothoracic width, 3.9; maximum prothoracic width, 5.3; humeral width, 6.1; elytral length, 9.0.

Type material: Holotype female from MEXICO, Chiapas: Lago de Colores, 12.V.1969, J.M. Campbell col. (MZSP).

Remarks: Scythropopsis intricata has a feature of Tetrasarus: tuft of setae on ventral surface of the antennomeres III and IV. However, the tuft of setae is much denser, and the antennomere IV is distinctly longer in species of Tetrasarus. Notwithstanding, it could be compared with Tetrasarus inops Bates, 1880 (see photograph of the lectotype at Bezark, 2019), by the similar elytral pubescence pattern, from which it differs, besides the two features pointed out before, by the proportions between elytra and head + prothorax (elytra distinctly shorter in S. intricata). In Scythropopsis, S. intricata is most similar to S. sallei, but differs by the tuft of setae on ventral surface of the antennomeres III and IV, which is absent in females of S. sallei.

Etymology: The name of this new species: "intricata" is in reference to the intricate pubescent pattern of the elytra.

\section{Scythropopsis lugens (Thomson, 1865), comb. nov.} (Fig. 100)

Psapharochrus lugens Thomson, 1865: 543; Lacordaire, 1872: 543; Thomson, 1878: 15 (type); Monné, 2019: 300 (cat.).

Acanthoderes lugens; Gemminger, 1873: 3146 (cat.); Bates, 1880: 140, 1885: 378; Blackwelder, 1946: 611 (checklist); Chemsak et al., 1992: 130 (checklist); Noguera \& Chemsak, 1996: 406 (cat.).
Acanthoderes (Psapharochrus) lugens; Aurivillius, 1923: 386 (cat.); Gilmour, 1965: 613 (cat.); Monné \& Giesbert, 1994: 231 (checklist); Monné, 1994: 64 (cat.). Aegomorphus lugens; Chemsak \& Noguera, 1995: 99; Monné, 2005: 166 (cat.).

Bates (1880) transferred Psapharochrus lugens to Acanthoderes but did not provide any explanation. Chemsak \& Noguera (1995) transferred Acanthoderes lugens to Aegomorphus also without explanation. However, Noguera \& Chemsak (1996) listed the species as Acanthoderes lugens. Probably this latter work was already in press when the transference to Aegomorphus was done. Nevertheless, examination of photograph of the holotype shows that the eyes are finely granulated, and the elytra have distinct carina. Accordingly, the species is transferred to Scythropopsis. Monné (2019), without any explanation, listed the species as Psapharochrus lugens.

Known geographical distribution (Monné, 2019; Tavakilian \& Chevillotte, 2019): Mexico (Mexico, Puebla, Veracruz).

\section{Aegomorphus Haldeman, 1847}

Psapharochrus Thomson, 1864: 18. Syn. nov.

\section{Aegomorphus wappesi (Galileo, Martins \& Santos- Silva, 2015), comb. nov.}

Psapharochrus wappesi Galileo et al., 2015: 87; Wappes \& Arias, 2016: 8 (holotype).

Psapharochrus jameswappesi Tavakilian, 2018: 40; Monné, 2019: 296 (cat.). Syn. nov.

As indicated previously, Tavakilian (2018) transferred Acanthoderes wappesi Chemsak \& Hovore, 2002 to Psapharochrus. Accordingly, this created a secondary homonymy with Psapharochrus wappesi Galileo et al., 2002. Tavakilian (2018) provided a new name for the younger homonymy: P. jameswappesi. However, with the transference of Acanthoderes wappesi to Scythropopsis, Psapharochrus wappesi Galileo et al., 2002 is reinstated as valid, and the former becomes its synonym (ICZN, 1999: Article 59.4).

Known geographical distribution (Monné, 2019; Tavakilian \& Chevillotte, 2019): Bolivia (Tarija).

\section{Aegomorphus contaminatus (Thomson, 1965), revalidation, comb. nov.}

(Fig. 40)

Psapharochrus contaminatus Thomson, 1865: 543, 1878: 15 (type).

Acanthoderes contaminata; Gemminger, 1873: 3145 (cat.); Blackwelder, 1946: 610 (checklist); Zajciw, 1969a: 197 (distr.), 1970b: 187 (distr.). 
Acanthoderes (Psapharochrus) contaminatus; Aurivillius, 1923: 386 (cat.).

Acanthoderes (Psapharochrus) contaminata; Gilmour, 1965: 615 (cat.).

Acanthoderes melanostictus; Monné \& Giesbert, 1992: 252 (syn.).

Even based on examination of the photograph of the holotype (Fig. 37) we were not able to place this species as a synonym (senior or junior) of another species currently included in Psapharochrus, Acanthoderes (including the subgenera), or other genera with species similar in general appearance to it. Thus, the species is considered valid and remains known only from the type locality indicated in the original description (Brazil). The original description and photograph of the holotype is not diagnostic enough to know whether the species really belongs to Aegomorphus. However, we doubt that the species is from Brazil and, most likely belongs in Scythropopsis. For now, until more information or specimens become available, it is transferred to Aegomorphus simply because of its original placement in Psapharochrus.

Known geographical distribution (Monné, 2019; Tavakilian \& Chevillotte, 2019): Brazil.

\section{Aegomorphus ramirezi (Chemsak \& Hovore, 2002), comb. nov.}

(Figs. 77-81)

Acanthoderes ramirezi Chemsak \& Hovore, 2002b: 5. Acanthoderes (Acanthoderes) ramirezi; Monné, 2005: 162 (cat.); Monné \& Hovore, 2006: 203 (checklist); Monné, 2019: 223 (cat.).

Examination of photograph of the holotype, as well as the specimens examined, indicates that the eyes are coarsely granulated. Accordingly, the species is transferred to Aegomorphus.

Material examined: MEXICO, Sonora (new state record): MX16 km 155, 1 male, 18.VII.2007, Skillman, Ribardo and Hildelbrandt col. (FWSC). Michoacán (new state record): Hwy MX37, 98 km S Nueva Italia, 1 female, 13.VII.2006, F.W. Skillman and D.C. Hildebrandt col. (MZSP, formerly FWSC). Jalisco: MX200, $21 \mathrm{~km} \mathrm{~N}$ Melaque, 1 female, 06.VII.2006, F.W. Skillman \& D.C. Hildebrandt col. (ACMT, formerly FWSC).

Known geographical distribution (Monné, 2019; Tavakilian \& Chevillotte, 2019; new records): Mexico (Sonora, Jalisco, Michoacán).

\section{Aegomorphus maccartyi (Chemsak \& Hovore, 2002), comb. nov.}

(Figs. 82-86)

Acanthoderes maccartyi Chemsak \& Hovore, 2002a: 30.
Acanthoderes (Acanthoderes) maccartyi; Monné, 2005: 162 (cat.); Monné \& Hovore, 2006: 203 (checklist); Monné, 2019: 222 (cat.).

Examination of a photograph of the holotype, as well as available specimens, reveals that the eyes are coarsely granulated. Accordingly, the species is transferred to Aegomorphus.

Material examined: MEXICO, Jalisco: MX80, $20 \mathrm{~km} \mathrm{~S}$ Autlán (RMO Los Mazos), 1 male, 08.VII.2006, Skillman \& Hildebrandt col. (FWSC); El Tuito, 1 female, 14.VII.1993, Morris, Huether \& Wappes col. (RFMC); 6 km N El Tuito, 1 male, 15-16.VII.1993, Wappes col. (ACMT).

Known geographical distribution (Monné, 2019; Tavakilian \& Chevillotte, 2019): Mexico (Jalisco).

Aegomorphus albosignus Chemsak \& Noguera, 1995 (Figs. 87-99)

Aegomorphus albosignus Chemsak \& Noguera, 1995: 98; Monné, 2001: 38 (cat. hosts); Noguera et al., 2002: 625 (distr.); Monné, 2005: 165 (cat.); Monné \& Hovore, 2006: 203 (checklist); Noguera et al., 2009: 89 (distr.); Luna-León et al., 2015: 838 (distr.); Martins et al., 2015: 838 (key); Zaragoza-Caballero \& PérezHernández, 2017: 30 (holotype); Noguera et al., 2017: 11 (distr.); Monné, 2019: 227 (cat.).

Aegomorphus albosignus was described from males and females from Mexico (Jalisco). According to Chemsak \& Noguera (1995) "this species is readily recognizable by the pale pubescent face and the white oblique and longitudinal fasciae of the elytra" However, as in many other species of Aegomorphus, Acanthoderes, and Scythropopsis the elytral pubescent pattern, as well as the color of the pubescence of the frons are extremely variable. This is clearly shown in the type series (see photographs at Bezark, 2019) where the longitudinal white pubescent band on the elytra varies from being well defined, slightly distinct or even absent or nearly so (Fig. 92-98). Thus, it can be difficult to recognize the species, which is only possible by examining other details provided in the original description.

Material examined: MEXICO, Michoacán (new state record): MX 37, km 98, S Nueva Italia, 2 males, 1 female, 13.VII.2006, Skillman \& Hildebrant col. (FWSC); 2 males, 3 females, 15.VII.2006, Skillman \& Hildebrant col. (FWSC). Colima (new state record): Hwy MX98, km 33, N Manzanillo, 1 male, 11.VII.2006, Skillman \& Hildebrant col. (FWSC). Jalisco: MX200, 5 km N Campo Acosta, 6 males, 3 females, 21.VII.2006, Skillman \& Hildebrant col. (FWSC); MX200, at km marker 59, Chamela Bio Station, 1 female, 09.VII.2006, Skillman \& Hildebrant col. (FWSC); 21 km N Melaque, 1 male, 06.VII.2006, Skillman \& Hildebrant col. (FWCS). Guerrero: Hwy. GRO1, 1 km S Taxco El Viejo, 1 male, 26.X.2006, Skillman \& Eya col. (FWSC). Sonora: 

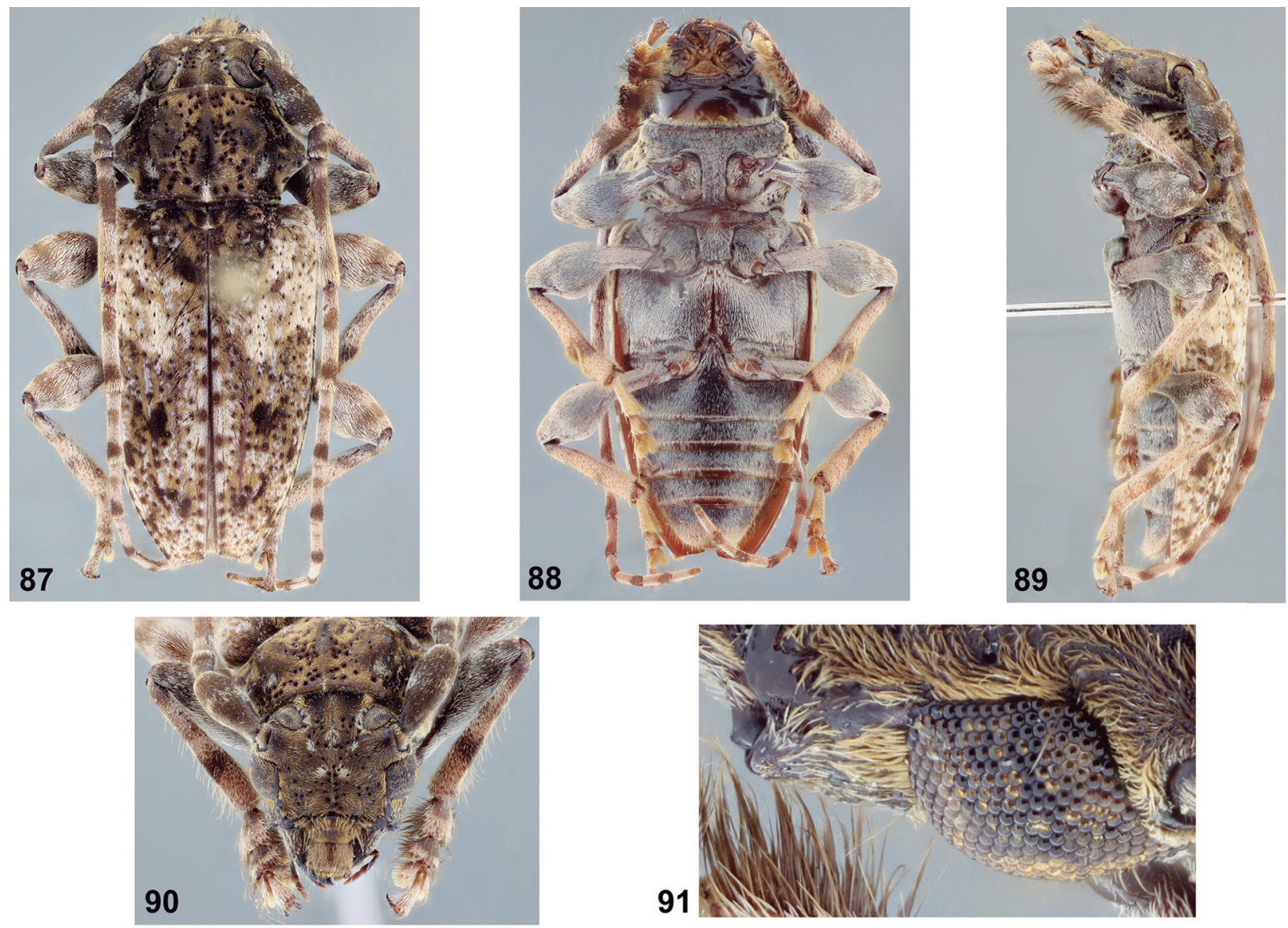
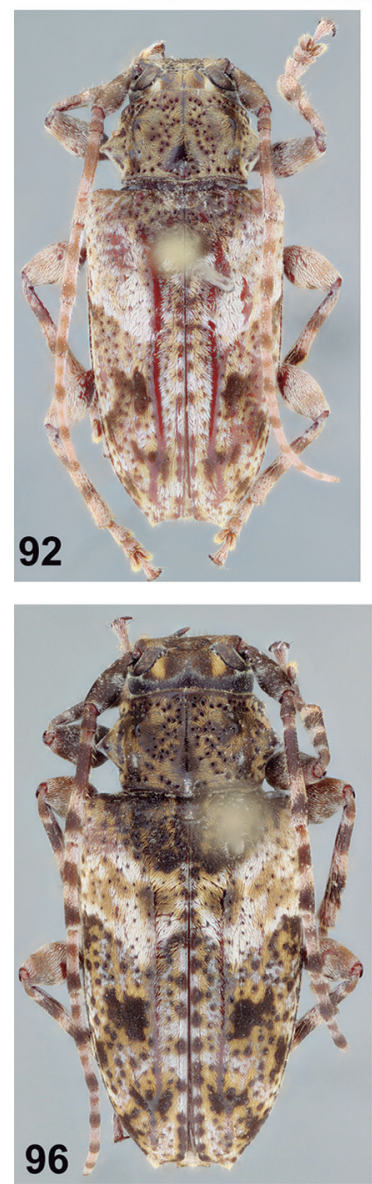
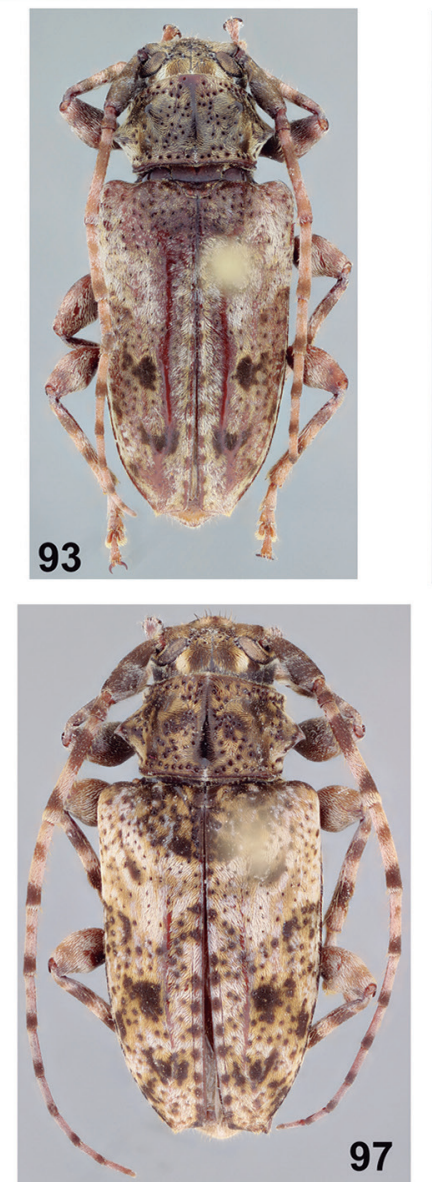
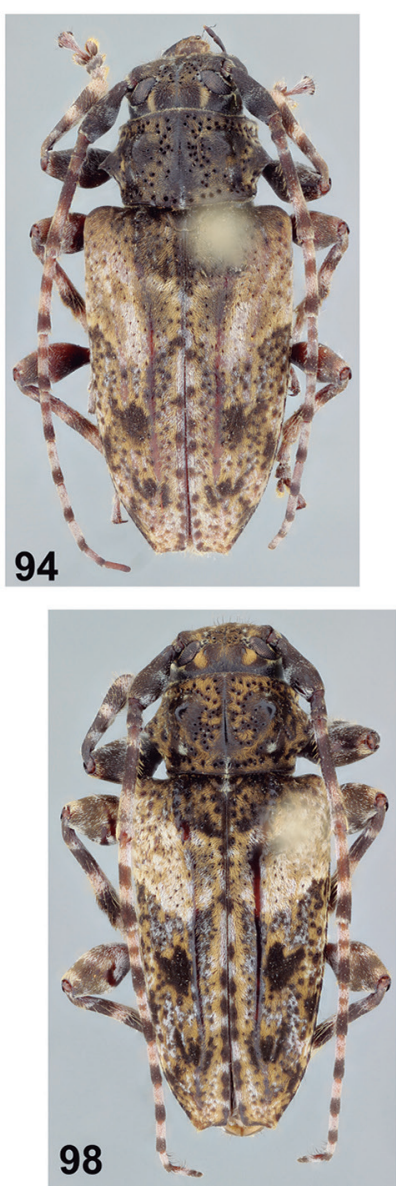
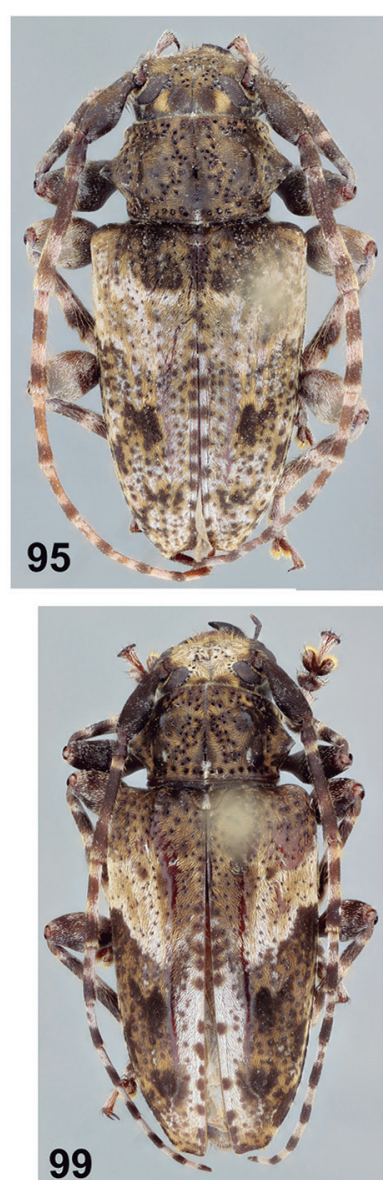

Figures 87-99. (87-91) Aegomorphus albosignus, male from Mexico (Jalisc0). (87) Dorsal habitus. (88) Ventral habitus. (89) Lateral habitus. (90) Head, frontal view. (91) Lower eye lobe. (92-99) Specimens from Mexico, dorsal habitus. (92) Female from Jalisco. (93) Female from Jalisco. (94) Female from Michoacán. (95) Male from Michoacán. (96) Female from Michoacán. (97) Female from Michoacán. (98) Male from Guerrero. (99) Female from Michoacán. 

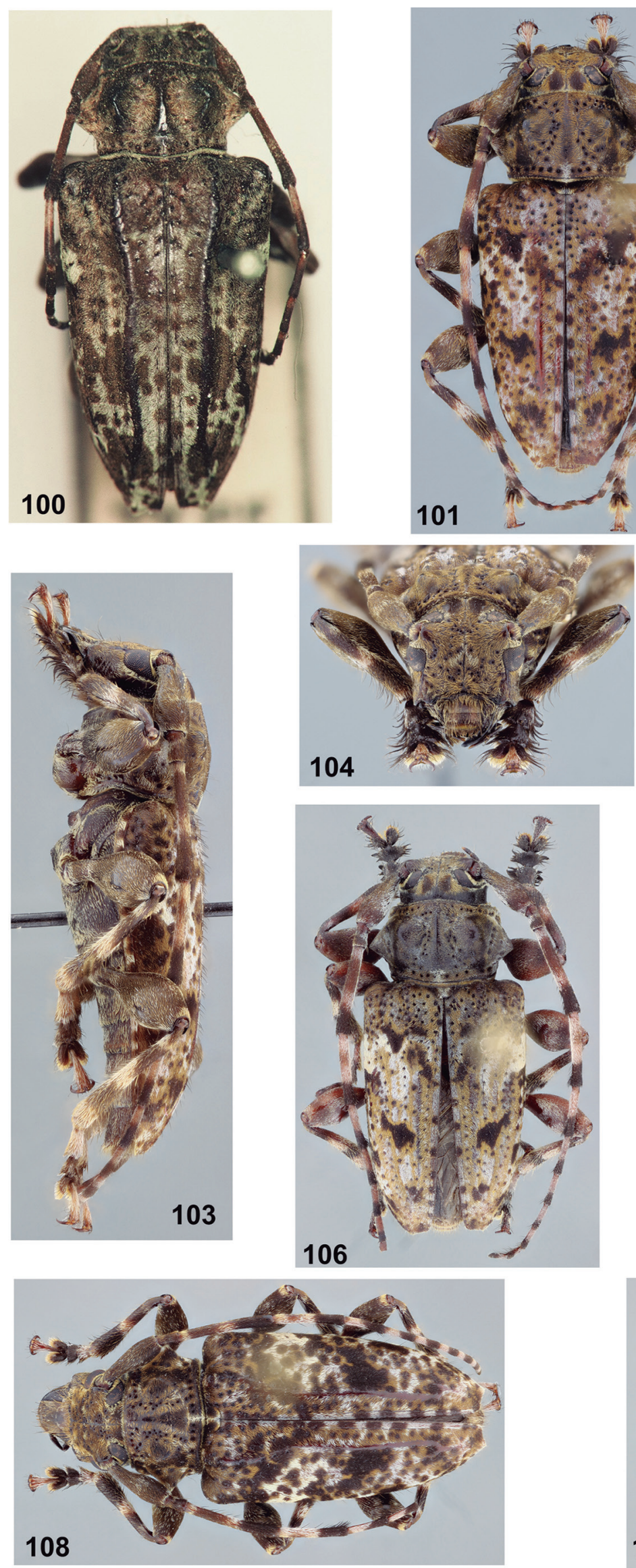

105
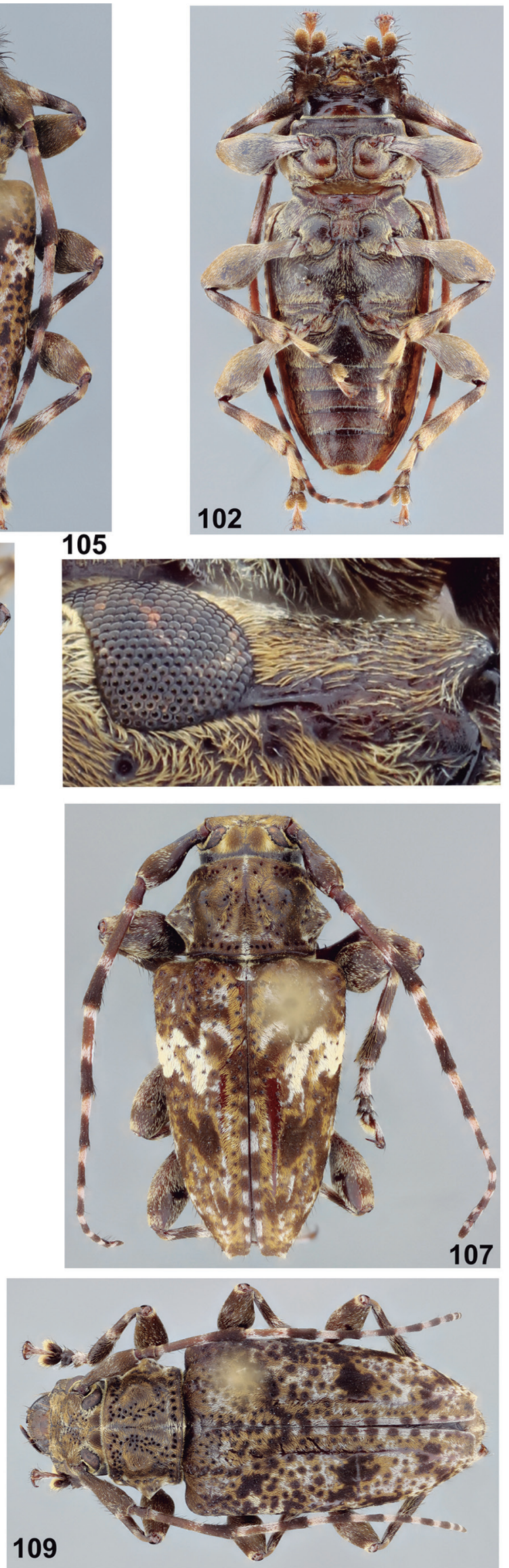

Figures 100-109. (100) Psapharochrus lugens, holotype, dorsal habitus. (101-109) Aegomorphus quadrigibbus. (101) Male, specimen 1, from Mexico (Guerrero), dorsal habitus. (102) Male, specimen 1, from Mexico (Guerrero), ventral habitus. (103) Male, specimen 1, from Mexico (Guerrero), lateral habitus. (104) Male, specimen 1, from Mexico (Guerrero), head, frontal view. (105) Male, specimen 1, from Mexico (Guerrero), lower eye lobe. (106) Male, specimen 2, from Mexico (Guerrero), dorsal habitus. (107) Male, specimen 3, from Mexico (Veracruz). (108) Female, specimen 1, from Mexico (Guerrero). (109) Female, specimen 2, from Mexico (Guerrero). 
MX16, km 155, 05.VII.2008, 1 male, Skillman, O'Brien \& Ribardo col. (FWSC); MX16, km 155, 18.VII.2007, 2 males, Skillman, O'Brien, Ribardo \& Hildebrandt col. (ACMT); MX16, km 155, 02.VII.2008, 1 male, Skillman, O'Brien \& Ribardo col. (FWSC).

Known geographical distribution (Monné, 2019; Tavakilian \& Chevillotte, 2019; new records): Mexico (Jalisco, Morelos, Guerrero, Sonora, Oaxaca, Michoacán, Colima).

\section{Aegomorphus quadrigibbus (Say, 1831) (Figs. 101-109)}

Acanthocinus quadrigibbus Say, 1831: 9, 1835: 195; LeConte, 1859: 665.

Acanthoderes quadrigibbus; Haldeman, 1847: 45; LeConte, 1852: 175; Melsheimer, 1853: 107 (cat.); Bland, 1861: 97 (distr.); LeConte, 1873: 337, 1880: 237 (hosts); Packard, 1881: 55, 75, 131 (biol.); LeConte \& Horn, 1883: 322; Shufeldt, 1884: 334, 338 (distr.); Townsend, 1884: 222; Harrington, 1884: 48 (hosts); Townsend, 1885: 70 (distr.); Chittenden, 1894: 99 (hosts); Knobel, 1895: 34; Hamilton, 1895: 339 (distr.); Leng \& Hamilton, 1896: 114; Wickham, 1897: 206; Harrington, 1897: 74 (hosts); Smith, 1900: 294 (distr.); Dury, 1902: 162 (distr.); Ulke, 1903: 26 (distr.); Felt, 1906: 702, 715 (biol.); Smith, 1910: 333; Blatchley, 1910: 1070; Fisher \& Kirk, 1912: 314 (distr.); Johnson, 1915: 315 (distr.); Nicolay, 1919: 70 (distr.); Craighead, 1923: 113 (larva); Turnbow \& Franklin, 1980: 344 (distr.).

Psapharochrus quadrigibbus; Lacordaire, 1872: 751; Casey, 1913: 301; Champlain et al., 1925: 140 (hosts); Kirk \& Knull, 1926: 42 (distr.); Leonard, 1928: 451 (distr.); Beaulne, 1932: 219 (hosts); Pechuman, 1937: 12 (biol.); Brimley, 1938: 217; Kaston, 1938: 239 (biol.); Hoffman, 1942: 11; Knull, 1944: 92 (distr.); Beal \& Massey, 1945: 148 (biol.); Loding, 1945: 122 (distr.); Knull, 1946: 243; Fattig, 1947: 33 (distr.); Jaques, 1951: 267; Alexander, 1958: 49 (distr.); Solomon et al., 1976: 290; Monné, 2005: 211 (cat.).

Acanthoderes quadrigibba; Gemminger, 1873: 3146 (cat.); Horn, 1880: 115; Franz, 1954: 226 (distr.); Duffy, 1960: 214 (larva, biol.); Gilmour, 1965: 613 (cat.); Zajciw, 1969b: 609 (distr.); Perrault, 1978: 380 (distr.); Rice \&Enns, 1981: 92 (distr., hosts); Chemsak \& Hovore, 2002b: 12; Hernández-Fuentes et al., 2018: 544 (distr.; host).

Acanthoderes (Acanthoderes) quadrigibba; Swift et al., 2010: 45 (distr.); Maes et al., 2010: 319 (distr.); Audureau, 2010: 8 (distr.); Holt, 2013: 252 (distr.); Klingeman et al., 2017: 298 (distr.); Audureau \& Roguet, 2018: 76 (distr.); Monné, 2019: 222 (cat.).

Acanthoderes 4-gibbus; Riley, 1880: 270 (hosts); Packard, 1890: 91, 221, 291, 520 (biol.); Caulfield, 1890: 66 (hosts); Beutenmuller, 1896: 78 (hosts).

Aegomorphus quadrigibbus; Linsley \& Chemsak, 1985: 246 (syn.); Hovore et al., 1987: 316 (distr.); Chemsak et al.,
1992: 131 (checklist); Lingafelter \& Horner, 1993: 183 (distr.); MacRae, 1993: 244 (distr.); Monné \& Giesbert, 1994: 35 (checklist); Monné, 1994: 35 (cat.); Yanega, 1996: 133; Noguera \& Chemsak, 1996: 406 (distr.); Linsley \& Chemsak, 1997: 339 (hosts); Peck \& Thomas, 1998: 122 (distr.); Schiefer, 1998: 125 (distr.); Monné, 2001: 39 (cat. hosts); Vlasak \& Vlasakova, 2002: 214 (hosts).

Acanthoderes (Psapharochrus) quadrigibba; Aurivillius, 1923: 387 (cat.).

Psapharochrus quadrigibbus lucidus Knull, 1958: 282; Chemsak, 1977: 178 (type).

Acanthoderes (Psapharochrus) quadrigibba lucidus; Gilmour, 1965: 613 (cat.).

Although originally described in Acanthocinus by Say, 1831 and moved to Acanthoderes by Haldeman (1847) it was Lacordaire (1872) who finally transferred Acanthoderes quadrigibbus to Psapharochrus, affirming that this latter genus included most of the species allocated in Acanthoderes at that time. Curiously, the species continued to be quoted as being in Acanthoderes, and it was Casey (1913) who finally correctly listed it again in Psapharochrus. Even so, the species continued to be mentioned as belonging to Acanthoderes, until Aurivillius (1923) moved Psapharochrus to the status of a subgenus of Acanthoderes and included A. quadrigib$b a$ in it. From Aurivillius (1923) to Rice \& Enns (1981) the species was mentioned in Psapharochrus (as a distinct genus) or in Acanthoderes (Psapharochrus). More recently, Linsley \& Chemsak (1985) transferred the species to Aegomorphus, but only because of their doubts: "Since the species of Acanthoderes sensu latu are extremely numerous the question of generic or subgeneric assignments is difficult and beyond the scope of this work... We are assigning our five species of 'Acanthoderes' to Aegomorphus Haldeman until the problem can be resolved for the entire group." Finally, Chemsak \& Hovore (2002b) transferred Aegomorphus quadrigibbus to Acanthoderes. The thinking behind what these authors were trying to do is somewhat mysterious, since they reported: "We have used the name Acanthoderes herein for placement of taxa which possess most of the characters of Acanthoderes varia and Aegomorphus decipiens, and which fit within the existing parameters of the genus sensu latu, without assignment to subgenera." We do not know for sure what "Acanthoderes varia" is, but it is likely Cerambyx varius Fabricius, 1787 (currently equal to Cerambyx clavipes Schrank, 1781, and placed in Aegomorphus). As Aegomorphus decipiens is the type species of Aegomorphus, this affirmation may have indicated their view that it was closely related to Acanthoderes. For sure, it was a transference based on doubts, and not on justified or definable features.

Acanthocinus quadrigibbus Say, 1831 has the eyes coarsely faceted, and pronotum not distinctly depressed centrally. Accordingly, it belongs to and is hereby transferred to Aegomorphus.

As correctly reported by Chemsak \& Hovore (2002b) for this species "the variation within and be- 
tween samples is considerable." The elytral pubescence (Figs. 101, 106-109) is extremely variable in concentration, but much less so in position of the maculae, and although the anterior light pubescent macula of the elytra is from slightly distinct to well-marked its placement on the elytra remains the same.

Material examined: MEXICO, Guerrero: Hwy 200, 51 km NE Ixtapa, 6 males, 4 females, 18-21.VII.1985, Wappes col. (ACMT); 1 female, 17-20.VII.1985, Wappes col. (ACMT). Quintana Roo (new state record): Hwy 307, 5 km S Cancun A.P., 1 male, 09.VI.2005, Skillman Jr. col. (FWSC); 1-5 km S Cancun, 1 male, 04.Vl.2009, Skillman \& Hildebrant col. (FWSC). Veracruz: Laguna Catemaco, 1 male, 24-25.V.1969, J.E.H. Martin col. (MZSP); 1 male, 09.VI.1969, J.E.H. Martin col. (MZSP); 1 male, 25.VI.1969, Bright \& Campbell col. (MZSP); 1 male, 08-16.VIII.1969, H.F. Howden col. (MZSP). GUATEMALA (new country record): Baja Verapaz: CA14, km 149-151, 1 male, 2 females, 25.VII.2008, Skillman and C. \& L. O'Brien col. (FWSC).

Known geographical distribution (Monné, 2019; Tavakilian \& Chevillotte, 2019; new records): Canada, Eastern United States to Florida and Texas, Mexico (Chiapas, Guerrero, Jalisco, Yucatán, Nayarit, Quintana Roo), Guatemala, Nicaragua, Costa Rica.

\section{Aegomorphus circumflexus (Jacquelin du Val, 1857), nomem protectum, comb. nov. (Figs. 110-114)}

Acanthocinus rusticus Klug, 1829: 13. Nomen oblitum. Acanthoderus circumflexus Jacquelin DuVal, 1857: 270. Nomen protectum.

Acanthoderes circumflexus; Pascoe, 1866: 279 (distr.); Bates, 1872: 207, 1880: 140; Berry \& Salazar-Vaquero, 1957: 15 (distr.); Gregoire, 1957: 21 (physiol.); Zajciw, 1963: 590, 1964: 160; Linsley \& Chemsak, 1966: 242; Chemsak, 1969: 189 (distr.); Chemsak \& Linsley, 1980: 310 (distr.).

Acanthoderes circunflexus; Pittier \& Biolley, 1895: 28 (distr.).

Acanthoderes circunflexa; Terrón, 1997: 223 (distr.).

Acanthoderes circumflexa; Gemminger, 1873: 3145 (cat.); Gahan, 1895: 130; Leng \& Mutchler, 1914: 450 (distr.); Martorell, 1939: 204 (distr.); Fisher, 1944: 10 (distr.); Blackwelder, 1946: 610 (checklist); Wolcott, 1948: 342; Zayas, 1975: 225; Chemsak et al., 1980: 36 (distr.); Chemsak et al., 1992: 130 (cat.); Maes et al., 1994: 28 (distr.); Noguera \& Chemsak, 1996: 406 (cat.); Maes, 1998: 922 (distr.); Chemsak \& Hovore, 2002b: 10; Lozada Piña et al., 2004: 106 (distr.); Peck, 2005: 177 (distr.); Fernández García et al., 2009: 322 (distr.).

Acanthoderes (Psapharochrus) circumflexa; Aurivillius, 1923: 385 (cat.); Gilmour, 1965: 613 (cat.), 1968: 154 (distr.); Monné, 1994: 28 (cat.); Monné \& Giesbert, 1994: 230 (checklist).

Psapharochrus circumflexus; Monné, 2001: 47 (cat. hosts), 2005: 202 (cat.); Hovore, 2006: 376 (distr.); Hubweber,
2008: 255 (distr.); Swift et al., 2010: 46 (distr.); Maes et al., 2010: 368 (distr.); Morales-Morales et al., 2012: 38, 45 (distr.; biol.); Thomas et al., 2013: 20 (distr.); García Morales et al., 2014: 108 (distr.); LanuzaGaray \& Barrios, 2015: 68 (distr.); Audureau \& Roguet, 2018: 77 (distr.); Monné, 2019: 292 (cat.).

Psopharochrus circumflexus; Chevrolat, 1862: 247; Gundlach, 1891: 205.

Psapharochrus circumflexa; Turnbow et al., 2003: 28 (distr.).

Psapharochrus circumflexum; Audureau, 2008: 14 (distr.). Acanthoderus meteorica Gistel, 1857: 79; Aurivillius, 1923: 385 (syn.).

Psapharochrus histrio Casey, 1913: 302; Turnbow et al., 2003: 29 (distr.); Monné, 2005: 205 (cat.); Lingafelter et al., 2014: 76 (holotype); Monné, 2019: 295 (cat.). Syn. nov.

Acanthoderes (Psapharochrus) histrio; Aurivillius, 1923:386 (cat.); Gilmour, 1965: 614 (cat.); Monné, 1994: 61 (cat.); Monné \& Giesbert, 1994: 230 (checklist).

Acanthoderes histrio; Blackwelder, 1946: 610 (checklist); Chemsak et al., 1992: 130 (checklist).

Psapharochrus guatemalensis Casey, 1913: 303; Monné, 2005: 204 (cat.); Hovore, 2006: 376 (distr.); Lingafelter et al., 2014: 73 (holotype); Monné, 2019: 295 (cat.). Syn. nov.

Acanthoderes (Psapharochrus) guatemalensis; Aurivillius, 1923: 386 (cat.); Gilmour, 1965: 614 (cat.); Monné, 1994: 61 (cat.); Monné \& Giesbert, 1994: 230 (checklist).

Acanthoderes guatemalensis; Blackwelder, 1946: 610 (checklist); Chemsak et al., 1992: 130 (checklist).

According to Jacquelin du Val (1857): "Acanthoderus circumflexus, Klug"; and "Acanthoderus rusticus, Dej., Cat. Col., 3 édit., p. 362." There are some mistakes in those statements: 1. The genus was reported as "Acanthoderus" instead to Acanthoderes; 2. Klug (1829) described the species as "Acanthocinus rusticus: 198. Acanthocinus rusticus Dej. (i. litt.) fuscus, nigro-punctatus, coleoptris fascia transversa dentata interrupta grisea. (Minor A. depresso)."

According to Dejean (1835, 1836), "Acanthoderus. Serville" is equal to Acanthocinus. "Mergele. Dej. Catal."; and "Rusticus. Dej. Cuba" is equal to Circumflexus. "Klug. id." As there is no species formally described by Johann Christoph Friedrich Klug as "circumflexus" in Cerambycidae, it seems evident that Jacquelin du Val (1857) attributed the species to him based on information by Dejean (1835, 1836), indicating ("Acanthoderus" rusticus equal to "Acanthoderus" circumflexus Klug). Thus, Klug (1829) described the species as Acanthocinus rusticus (with a description provided, making the description taxonomically technically available (ICZN, 1999)). Accordingly, Acanthoderes circumflexus Jacquelin du Val, 1857 is a junior synonymy of Acanthocinus rusticus Klug, 1829 (= Psapharochrus rusticus (Klug, 1829)). However, both the conditions demanded by ICZN (1999: Article 23.9.1.1 and 23.9.1.2) to preserve a commonly used name are met, Acanthoderus circumflexus Jacquelin Du Val, 1857 is hereby valid and a nomen protectum (ICZN, 
1999: Article 23.9.2), and Acanthocinus rusticus Klug, 1829 , is hereby a nomen oblitum. A list of works giving evidence of the validity of Acanthoderus circumflexus by use of its name as a valid taxon is given in the ICZN reference above.
Material examined: MEXICO, Jalisco (new state record): MX200, 21 km N Melaque, 1 male, 06.VII.2006, Skillman \& Hildebrand col. (FWSC). Oaxaca: MX190, $11 \mathrm{~km} \mathrm{SE}$ Zanatepec, 1 male, 20.X.2001, Skillman \& Davidson col. (FWSC); Finca San Carlos (30 km E Palomares), 1 female,
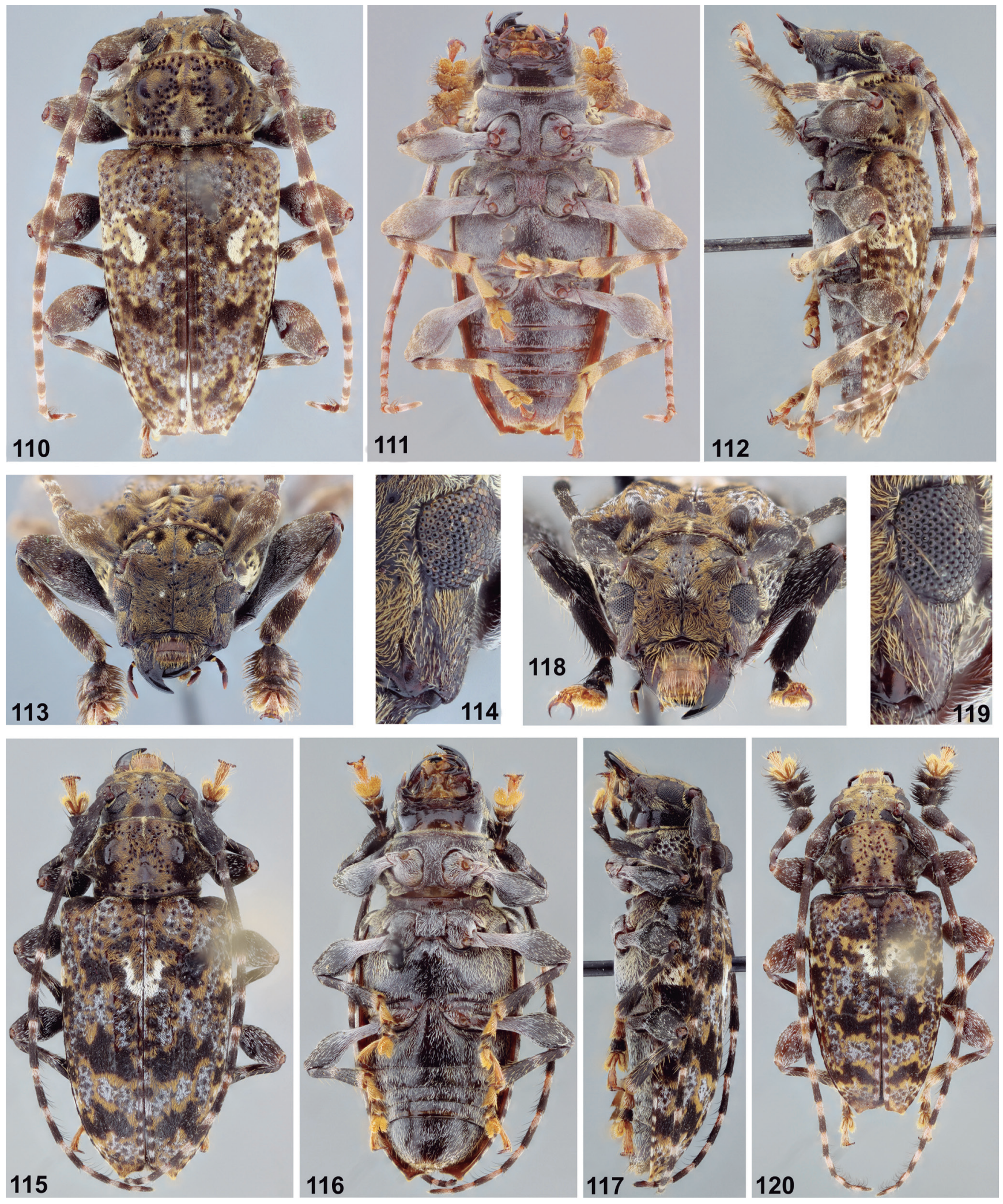

Figures 110-120. (110-114) Aegomorphus circumflexus, male from Cuba. (110) Dorsal habitus. (111) Ventral habitus. (112) Lateral habitus. (113) Head, frontal view. (114) Lower eye lobe. (115-120) Aegomorphus irumus. (115) Dorsal habitus, female. (116) Ventral habitus, female. (117) Lateral habitus, female. (118) Head, frontal view, female. (119) Lower eye lobe, female. (120) Dorsal habitus, male. 
29.V.1959, G. Halftter col. (MZSP). Michoacán (new state record): Tuxpan, 1 male, VIII.1960, G. Halftter col. (MZSP). Morelos (new state record): Cuernavaca, 1 female, no date and collector indicated (MZSP). Distrito Federal (new state record): 1 male, 23.V.1956, G. Halftter col. (MZSP). Veracruz: Playa de San Vicente, 1 male, II.1910, C.C. Halfmann col. (MZSP). Puebla (new state record): Villa Juarez (La Ceiba), 1 male, X.IV.1953, L. Vesguez col.
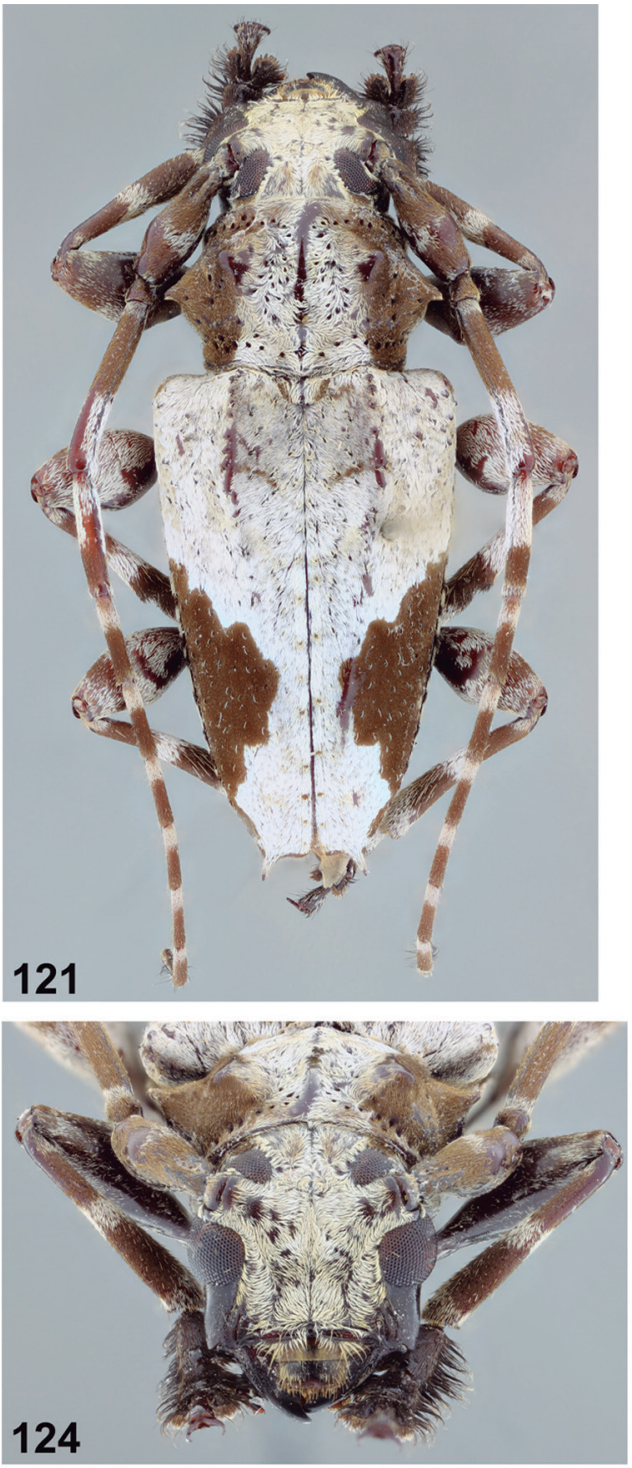
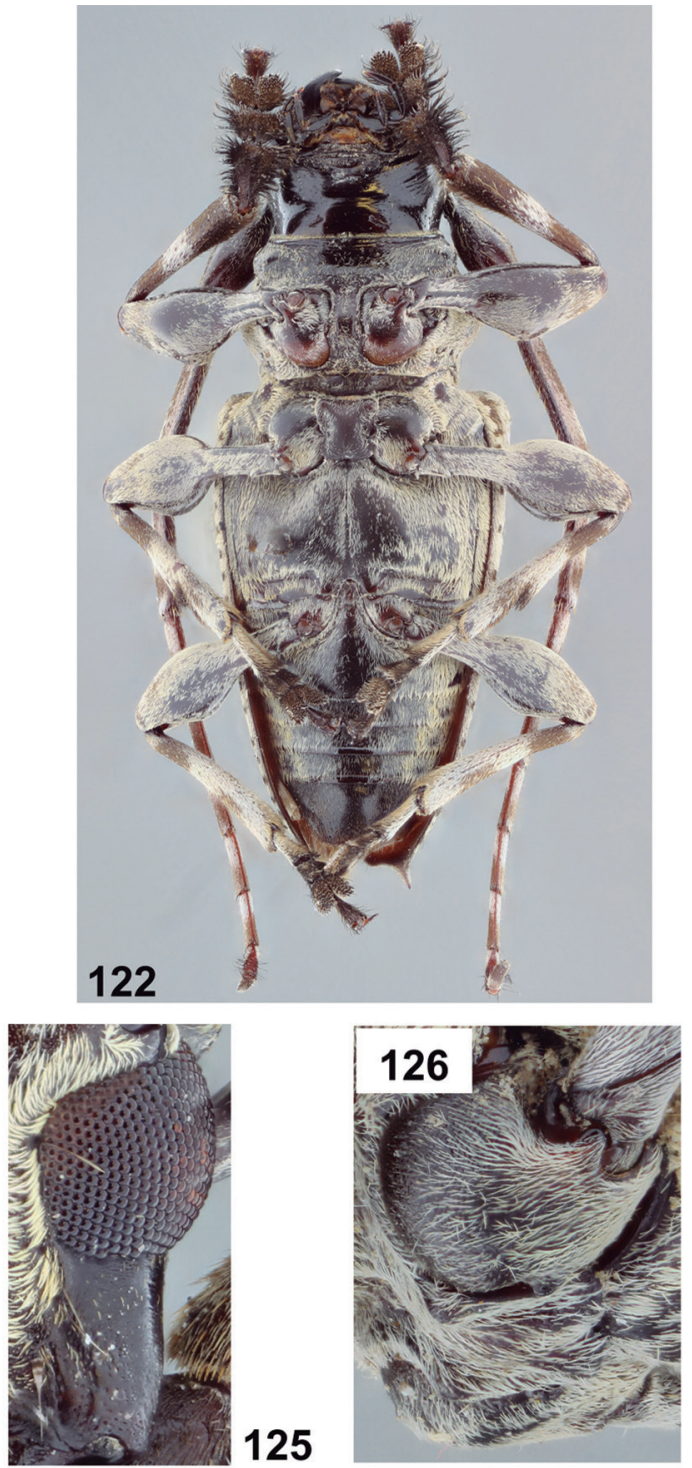
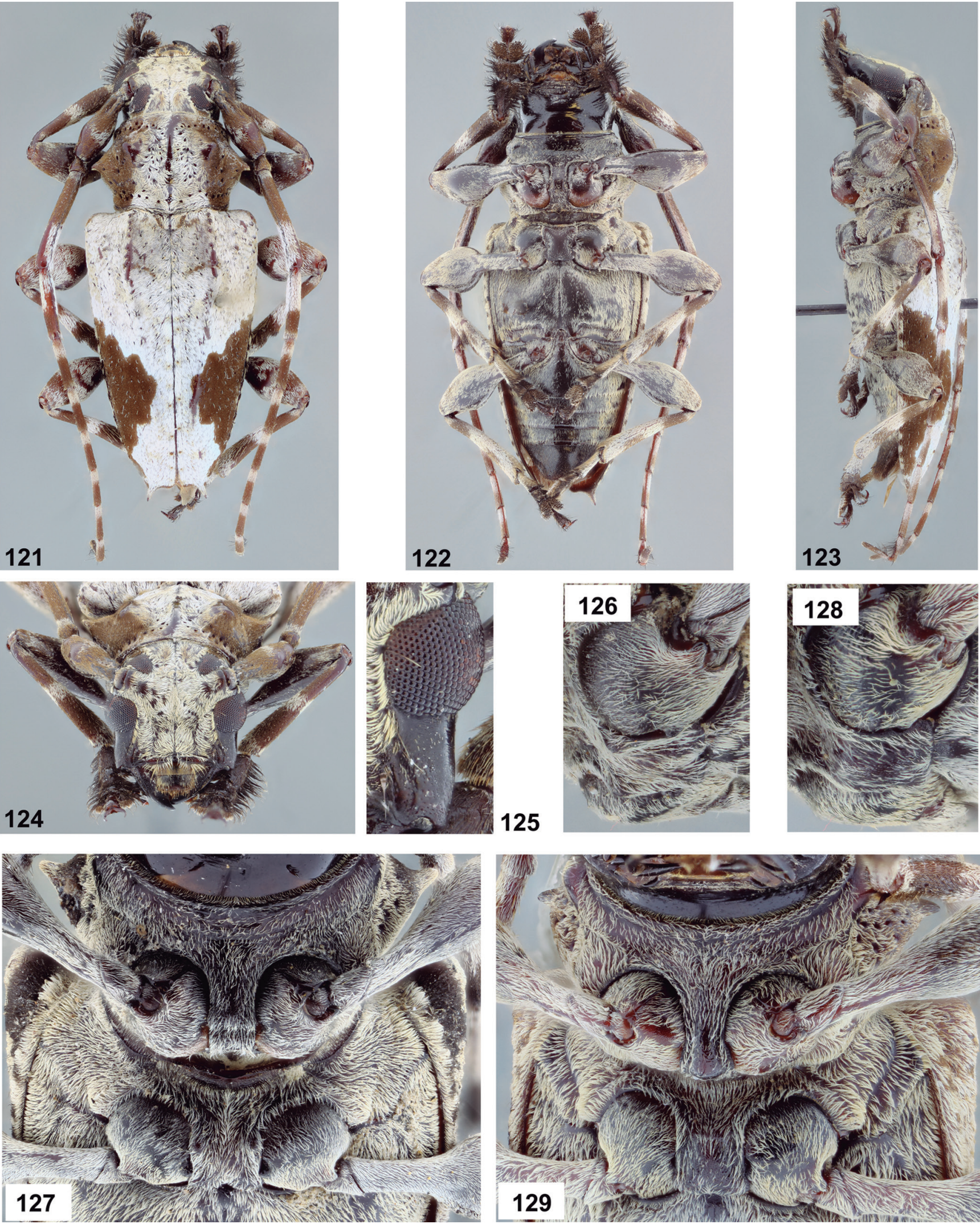

Figures 121-129. (121-125) Aegomorphus consentaneus, male from Bolivia. (121) Dorsal habitus. (122) Ventral habitus. (123) Lateral habitus. (124) Head, frontal view. (125) Lower eye lobe. (126-127) Aegomorphus satellinus, mesoventral process, male from Bolivia. (128-129) Aegomorphus jaspideus, mesoventral process, male from Bolivia. 
(MZSP). Quintana Roo: 1 female, IV.1967, no collector indicated (MZSP); Palenque, 1 male, 07-09.V.1969, Bright \& Campbell col. (MZSP). GUATEMALA, Escluinta: El Salto, 1 male, 1934, F.A. Bianchi col. (MZSP). BELIZE (new country record): Toledo: Punta Gorda, 1 male, no date and collector indicated (MZSP). EL SALVADOR (new country record): San Salvador: San Salvador, 1 female, XI.1960, collector illegible (MZSP). COSTA RICA, Guanacaste: Canas, 1 male, 1 female, 10.V.1991, D.B. Thomas col. (ACMT). Cartago: Turrialba, 1 female, 13.III.1970, no collector indicated (MZSP). Limón: near Cahuita town $\left(09.6827^{\circ} \mathrm{N}, 82.8105^{\circ} \mathrm{W}\right), 1$ male, VI.2015, A. Kozlov col. (MZSP). PANAMA, Panama: Barro Colorado Island, 1 male, 05-08.VIII.1965, B. Malkin \& S. Rand col. (MZSP); 1 female, XI.1965, H. Britski (MZSP). CUBA, Corralillo [there are places with this name in more than one province], 3 males, 9 females, VI.1951, Zayas col. (MZSP); 1 male, VI.1958, Zayas col. (MZSP). Sierra del Rosario [this place extends into two provinces: Pinar del Rio, and Artemisa], 1 female, 07.VII.1933, A. Bierig col. (MZSP); 1 male, 15.X.1933, A. Bierig col. (MZSP). Portugalete [there are places with this name in more than one province], $1 \mathrm{fe}$ male, 17.II.1929, A. Bierig col. (MZSP). La Habana: Habana, 1 female, V.1927, A. Bierig col. (MZSP); 1 male, VI.1928, A. Bierig col. (MZSP); 1 female, IV.1932, A. Bierig col. (MZSP). Artemisa: Aspiro (Sierra del Rosario), 1 male, 06.V.1934, A. Bierig col. (MZSP); 3 males, 1 female, 29.VI.1934, A. Bierig col. (MZSP). COLOMBIA, Bolívar: Zambrano (Hacienda Monterey, $\left.09^{\circ} 45^{\prime} \mathrm{N}, 74^{\circ} 49^{\prime} \mathrm{W}, 10 \mathrm{~m}\right), 1$ female, 09.IX.1993, F. Fernandez col. (MZSP). VENEZUELA, Distrito Capital: Caracas, 1 female, 15.VII.1959, Bordon col. (MZSP); 1 female, 10.VII.1960, Bordon col. (MZSP).

Known geographical distribution (Monné, 2019; Tavakilian \& Chevillotte, 2019; new records): Mexico (San Luís Potosí, Veracruz, Oaxaca, Chiapas, Yucatán, Tamaulipas, Quintana Roo, Jalisco, Michoacán, Morelos, Puebla, Distrito Federal), Guatemala, Honduras, El Salvador, Belize, Nicaragua, Costa Rica, Panama, Cuba, Puerto Rico, Cayman Islands, Curaçao, Colombia, Venezuela.

\section{Aegomorphus irumus (Galileo \& Martins, 2011), comb. nov.} (Figs. 115-120)

Psapharochrus irumus Galileo \& Martins, 2011: 178; Wappes \& Arias, 2016: 8 (holotype); Monné, 2019: 296 (cat.).

Description: Female (Figs. 115-119): Integument mostly black; mouthparts reddish-brown, except maxillary palpomeres II-IV, and labial palpomeres II-III black with reddish-brown apex; anteclypeus, labrum, protarsomeres III-V, meso- and metatarsomeres I and III-V reddish-brown; antennomere IV with basal and medial dark reddish-brown rings; remaining antennomeres dark reddish-brown on basal half; apex of meso- and metatibiae yellowish-brown.
Head: Frons coarsely, sparsely punctate; with yellowish-brown pubescence partially obscuring integument, white pubescence centrally, between lower eye lobes and antennal tubercles; with a few long, erect dark setae (apex yellowish) close to lower eye lobes. Area between antennal tubercles and upper eye lobes with central diamond-shaped area, coarsely, sparsely punctate, with sparse yellowish-white pubescence with yellowish-brown pubescence interspersed, sides of posterior area with denser yellowish-brown pubescence; sides extending toward prothorax with dense yellowish-brown pubescent band, narrow nearly glabrous area close to eyes. Central area of vertex close to prothorax with one large semielliptical area with brown pubescence on each side of median groove. Area behind eyes with yellowish-brown pubescence close to eyes (this area widened toward ventral surface), with white pubescence interspersed, glabrous toward prothorax. Genae about as long as lower eye lobe; with sparse light yellowish-brown pubescence, sparser toward apex. Postclypeus centrally and laterally glabrous, with bristly yellowish-brown pubescence on remaining surface, with long setae of same color interspersed, and a few long, erect dark setae. Posterior $3 / 4$ of labrum coplanar with anteclypeus, inclined at anterior quarter; with short yellowish-white pubescence close to anteclypeus, gradually longer toward apex of coplanar area; anterior margin with fringe of nearly golden setae. Gulamentum smooth, wide posterior area glabrous, depressed, anteriorly with short yellowish-brown pubescence not obscuring integument. Distance between upper eye lobes 0.58 times length of scape; in frontal view, distance between lower eye lobes equal to length of scape. Antennae 1.6 times elytral length, reaching elytral apex at posterior quarter of antennomere VIII. Scape clavate, not sulcate dorsally; dark-brown pubescent with white pubescence interspersed, white pubescence more abundant ventrally, somewhat yellowish-brown on base of ventral surface; with long, erect, sparse yellowish setae ventrally. Pedicel dark-brown pubescent with white pubescence interspersed, especially ventrally; ventral surface with long, sparse, erect yellowish setae. Antennomeres III-IV with basal and almost central white pubescent rings (denser on IV); remaining surface with dark-brown pubescence; ventral surface with long, sparse, erect yellowish setae. Remaining antennomeres with white pubescence on light area, dark-brown pubescence on dark area; with long, sparse, erect dark setae ventrally (yellowish on anterior area of V). Antennal formula (ratio) based on length of antennomere III (only one female measured): scape $=0.72$; pedicel $=0.22 ; \mathrm{IV}=0.80 ; \mathrm{V}=0.56 ; \mathrm{VI}=0.48$; $\mathrm{VII}=0.46 ; \mathrm{VIII}=0.38 ; \mathrm{IX}=0.36 ; \mathrm{X}=0.28 ; \mathrm{XI}=0.26$.

Thorax: Lateral conical tubercle of prothorax large, slightly inclined upward, with apex acute. Pronotum with large, elevated tubercle on each side, with top of tubercle truncate and somewhat bifid; a smaller, somewhat conical central tubercle at posterior half; coarsely, moderately abundantly punctate between tubercles, and between anterior margin and lateral tubercles, coarser 
along posterior sulcus; punctures sparser, shallower on lateral tubercles of prothorax; tubercles glabrous on top; central area with yellowish-brown pubescence not obscuring integument, except narrow, longitudinal pale yellow-pubescent band anteriorly and posteriorly, and white pubescence on sides of posterior quarter; area between side of lateral tubercles and on lateral tubercles of prothorax with brown, yellowish-brown, and whitish pubescence intermixed. Sides of prothorax coarsely, moderately abundantly punctate; with white pubescence not obscuring integument, more yellowish anteriorly and posteriorly. Prosternum centrally with white pubescence not obscuring integument, more yellowish laterally. Prosternal process with narrowest area about as wide as half the width of procoxal cavity; with white pubescence not obscuring integument. Ventral surface of meso- and metathorax with pale-yellow pubescence laterally, white centrally (sparser on center of mesoventrite). Mesoventral process slightly narrower than width of mesocoxal cavity; lateral margins elevated, especially anteriorly. Scutellum with dark brown pubescence, except narrow, central, longitudinal yellowish pubescent band (sometimes absent). Elytra: Humeri very slightly projected forward; with centrobasal crest between humeri and scutellum elevated, covered with small tubercles; with slightly distinct carina from apex of centrobasal crest to posterior third, and another between the crest and humeri; coarsely, sparsely punctate; apex obliquely truncate, with outer angle projected; irregular areas with white pubescence (not obscuring punctures) surrounded by yellowish-brown pubescence, except dense, white U-shaped pubescent macula centrally on anterior third (connecting across both elytra), and three large, somewhat transverse, irregular areas with dark-brown pubescence (one on anterior third; one about middle; another on posterior third). Legs: Femora with dense white pubescence on peduncle, sparser on club. Tibiae with three white pubescent rings, one near base, one about middle, another at apex; remaining surface with brown pubescence not obscuring integument, with long, sparse, erect yellowish setae interspersed, especially in meso- and metatibiae.

Abdomen: Ventrites with white pubescence not obscuring integument; apex of ventrite $V$ narrow, truncate.

Variation: Elytral pubescence is noticeably variable as in several species of Aegomorphus. Extremes could easily be confused with different species. In some specimens (including the holotype), the sides of anterior half have dense white pubescence forming large band distinctly attaining center of dorsal area, in others this band is restricted to inclined area, and in some it is nearly absent. The same occurs in the fascia along the sides in posterior half.

Dimensions (mm), male (2)/female (2): Total length, 10.55-10.70/10.60-10.95; prothoracic length, 2.05-2.10/1.90-2.00; anterior prothoracic width, 2.65-2.80/2.60-2.80; posterior prothoracic width, 2.55-2.65/2.35-2.70; maximum prothoracic width
3.40-3.70/3.35-3.65; humeral width, 3.90-4.10/3.90-4.30; elytral length, 6.85-6.90/6.85-7.25.

Material examined: BOLIVIA, Santa Cruz: 4-6 km SSE Buena Vista (F\&F Hotel), 1 male, 22-31.X.2002, Wappes col. (ACMT); 1 male, 26-27.X.2014, Wappes col. (ACMT); 4-5 km N Achira, road to Amboro, 1 female, 12-13.X.2000, Wappes \& Dozier

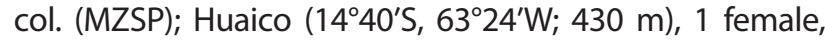
21.XI.2013, Skillman \& Wappes col. (FWSC).

Known geographical distribution (Monné, 2019; Tavakilian \& Chevillotte, 2019): Bolivia (Santa Cruz).

Remarks: The coarsely granulated eyes and the pronotum lacking a central depression places this species in Aegomorphus.

\section{Aegomorphus consentaneus (Thomson, 1865), comb. nov. \\ (Figs. 121-125)}

Psapharochrus consentaneus Thomson, 1865: 544, 1878: 15 (type); Monné, 2001: 47 (cat. hosts); Monné, 2005: 2034 (cat.); Monné, 2019: 293 (cat.).

Acanthoderes consentanea; Gemminger, 1873: 3145 (cat.); Lameere, 1884: 95 (distr.); Melzer, 1932: 223; Schottfeldt, 1944: 111 (hosts); Blackwelder, 1946: 610 (checklist); Zajciw, 1966: 9; Silva et al., 1968: 397 (hosts); Zajciw, 1969a: 198 (distr.), 1970b: 187.

Acanthoderes (Psapharochrus) consentanea; Aurivillius, 1923: 386 (cat.); Gilmour, 1965: 615 (cat.); Monné \& Giesbert, 1994: 230 (checklist); Monné, 1994: 60 (cat.).

Psapharochrus consentaneus was described by Thomson based on a single specimen from Brazil without a specific locality given. Lameere (1884) reported the species from "Env. De Rio-Janeiro.", referring to a place near to Rio de Janeiro city (Rio de Janeiro, Brazil) and more recently Zajciw (1969a) recorded the species to two Brazilian states (Minas Gerais and Rio de Janeiro). The MZSP collection has a large number of Cerambycidae from southern Brazil, but all specimens of $P$. consentaneus are only from Northern Brazil and Bolivia. Accordingly, it is possible that the specimens examined by Lameere (1884) and Zajciw (1969a) are not really P. consentaneus.

The eyes coarsely granulate, and the pronotum lacking a central depression place this species in Aegomorphus. One of the primary features allowing recognition of the species is the sparse white setae on the large dark pubescent area along the sides of the posterior half of the elytra. Only one other species of Aegomorphus has this pattern of pubescence: Aegomorphus pseudosatellinus (Tavakilian \& Néouze, 2013).

Material examined: BRASIL, Amazonas (new state record): Benjamin Constant (Rio Javari), 1 female, XI.1961, formerly Dirings collection (MZSP); 1 female, X.1962, formerly Dirings collection (MZSP); 1 male, X.1963, formerly Dirings collection (MZSP). Pará (new state record): 1 male, 1 female, 
no date and collector indicated (MZSP); Santarém, 1 female, VIII.1920, Hagmann col. (MZSP); (Fazenda Taperinha), 1 male, 01-11.ll.1968, no collector indicated (MZSP); Tucuruí (Rio Tocantins), 1 male, 03.VII.1984, W. Overall
(MZSP). BOLIVIA (new country record): Cochabamba: Chaparé (400 m), 3 females, XI.1957, formerly Dirings collection (MZSP); Villa Tunarí, 1 male, XI.1953, Prosen col. (MZSP). Santa Cruz: 4-6 km SSE Buena Vista (F\&F Hotel),
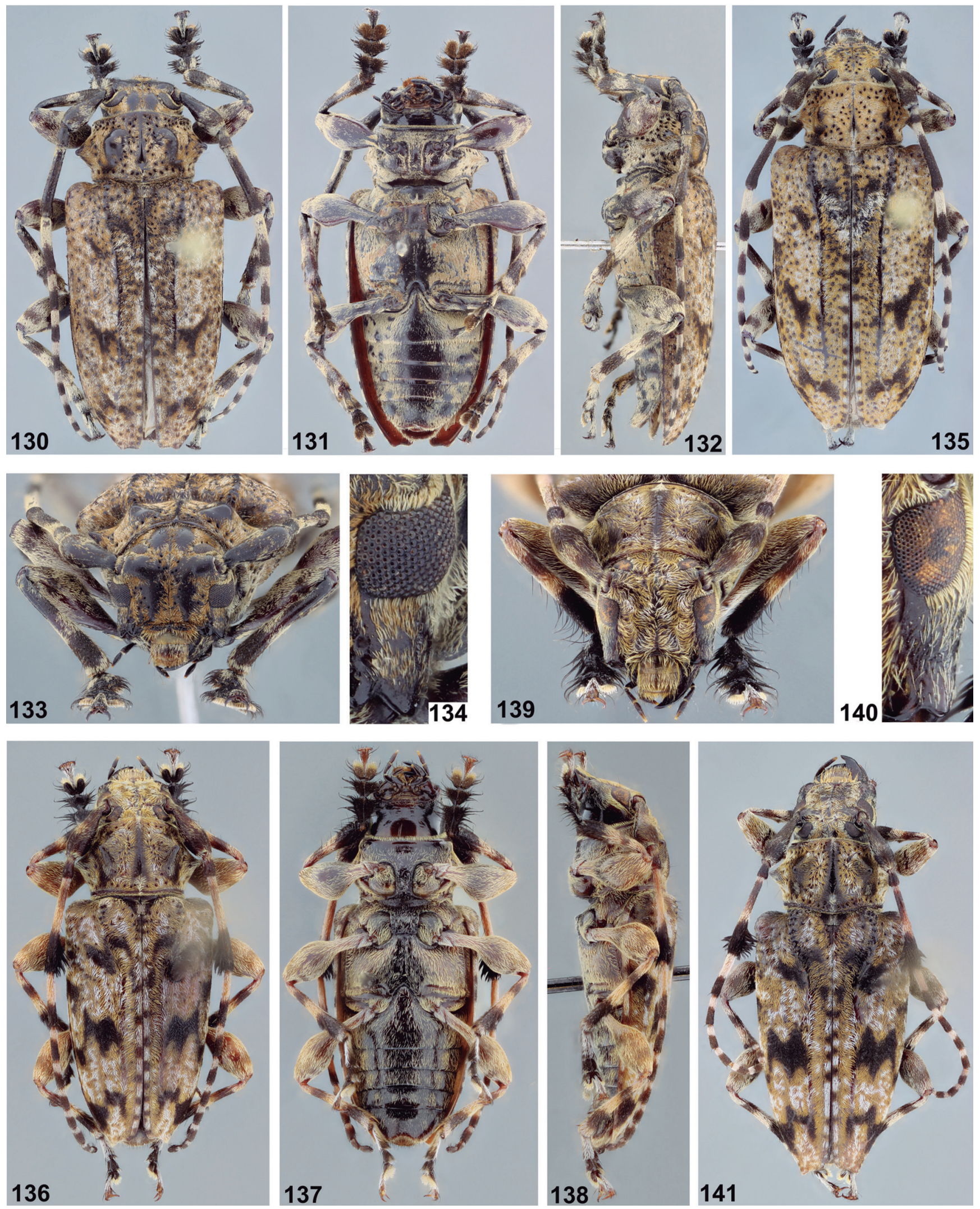

Figures 130-141. (130-135) Aegomorphus robustus sp. nov. (130) Dorsal habitus, holotype male. (131) Ventral habitus, holotype male. (132) Lateral habitus, holotype male. (133) Head, frontal view, holotype male. (134) Lower eye lobe, holotype male. (135) Dorsal habitus, paratype female. (136-141) Plagiosarus literatus. (136) Dorsal habitus, male. (137) Ventral habitus, male. (138) Lateral habitus, male. (139) Head, frontal view, male. (140) Lower eye lobe, male. (141) Dorsal habitus, female. 
1 male, 02-12.II.2000, J.E. Wappes col. (ACMT); 2 male, 1 female, 23-25.X.2000, R. Morris col. (RFMC); Reserva Natural

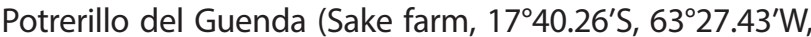
400 m), 1 male, 06-09.X.2006, Wappes, Nearns \& Eya col.
(ACMT); Potrerillo del Guenda (400 m), 1 female, 06-08. XII.2011, Morris \& Wappes col. (RFMC); (Reserva Natural, 40 km NW Santa Cruz, 17 $\left.40^{\prime} \mathrm{S}, 63^{\circ} 27^{\prime} \mathrm{W}, 370 \mathrm{~m}\right), 1$ female, 30.VII-03.X.2007, Wappes \& Morris col. (ACMT).
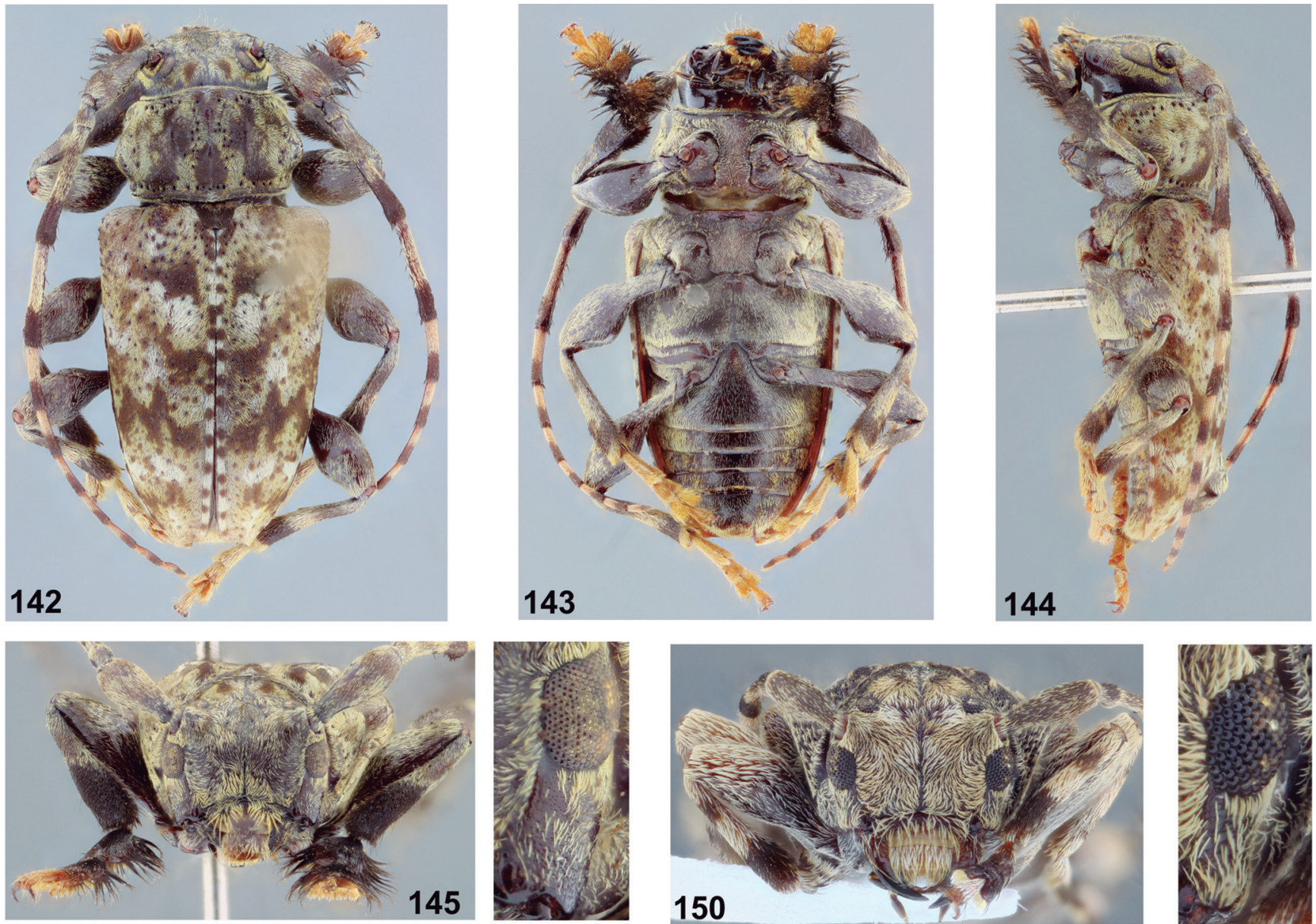

146
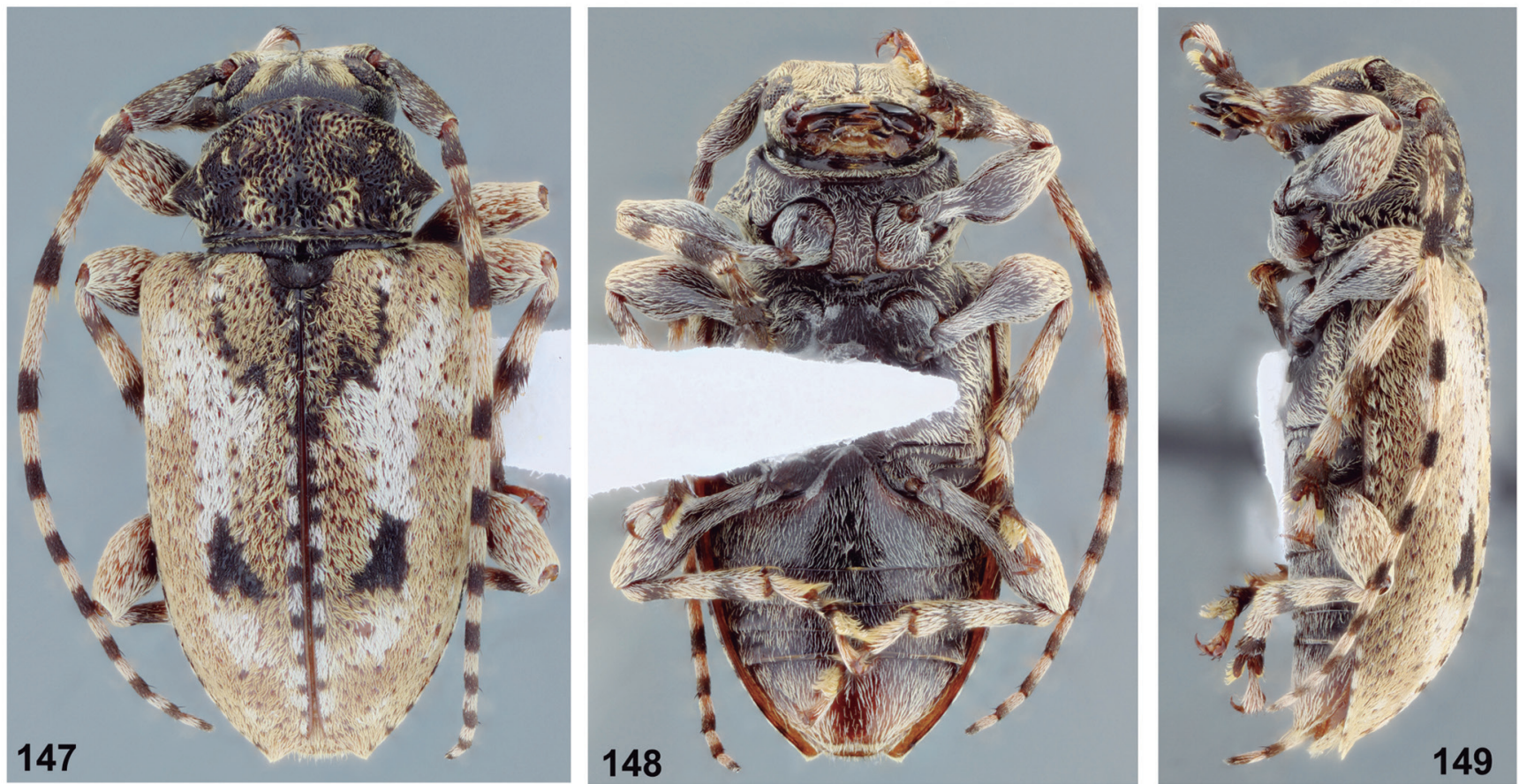

Figures 142-151. (142-146) Eupromerella quadrituberculata, male. (142) Dorsal habitus. (143) Ventral habitus. (144) Lateral habitus. (145) Head, frontal view. (146) Lower eye lobe. (147-151) Eupromerella boliviana holotype female. (147) Dorsal habitus. (148) Ventral habitus. (149) Lateral habitus. (150) Head, frontal view. (151) Lower eye lobe. 
Known geographical distribution (Monné, 2019; Tavakilian \& Chevillotte, 2019): Brazil (Amazonas, Pará, Minas Gerais, Rio de Janeiro), Bolivia.

\section{Aegomorphus satellinus (Erichson, 1847), comb. nov.} (Figs. 126-127)

Acanthoderes satellinus Erichson, 1847: 143; White, 1855: 357.

Acanthoderes satellina; Gemminger, 1873: 3147 (cat.); Blackwelder, 1946: 611 (checklist).

Psapharochrus satellinus; Lacordaire, 1872: 751; Monné, 2005: 212 (cat.); Wappes et al., 2006: 33 (distr.); Monné et al., 2012: 33 (distr.); Wappes et al., 2013: 10 (distr.); Monné, 2019: 305 (cat.).

Acanthoderes (Psapharochrus) satellina; Aurivillius, 1923: 388 (cat.); Gilmour, 1965: 614 (cat.); Monné \& Giesbert, 1994: 231 (checklist); Monné, 1994: 68 (cat.).

The general appearance of Aegomorphus satellinus is similar to that of Aegomorphus jaspideus (Germar, 1823) making it difficult to separate them simply from the dorsal view. Fortunately, the mesoventral process (Figs. 126-127) differs in the two species with A. satellinus having a somewhat centrally flattened process with a small tubercle on each side of anterior margin. In A. jaspideus, the mesoventral process (Figs. 128-129) is centrally tumid and lacks the tubercles.

Known geographical distribution (Monné, 2019; Tavakilian \&Chevillotte, 2019): Peru, Bolivia (Cochabamba, Santa Cruz), Brazil (Mato Grosso, Goiás).

\section{Aegomorphus robustus sp. nov. (Figs. 130-135)}

Description: Male (Figs. 130-134): Integument mostly black; mouthparts dark reddish-brown, except palpomeres black with apex yellowish; anteclypeus semitranslucent; apex of labrum light reddish-brown.

Head: Frons coarsely, sparsely punctate; with orangish-brown pubescence, partially obscuring integument (worn away in the holotype and many of the paratypes), with white pubescence interspersed and a few long, erect brown setae close to eyes. Area between antennal tubercles coarsely, sparsely punctate; with orange-brown pubescence partially obscuring integument, with yellowish-white pubescence interspersed, central area with yellowish-white pubescence. Area between upper eye lobes with orange pubescence (much of it missing in the holotype), with white pubescence interspersed. Central area of vertex close to prothorax with a large semielliptical area with short brown pubescence on each side of median groove (lost in the holotype), and orangish-brown pubescence along median groove. Area behind upper eye lobes with orange-white pubescence, with distinct yellowish-white pubescence close to ver- tex and dense, narrow yellowish-white pubescent band close to eye, widened toward inferior side, remaining surface glabrous. Genae almost 1.5 times length of lower eye lobe; with yellowish-white pubescence close to eye toward posterior area, with orangish-brown pubescence and white pubescence interspersed toward anterior area, glabrous apex. Postclypeus coarsely, sparsely punctate on wide central area, smooth laterally; with bristly orangish-brown pubescence on wide central area (nearly glabrous centrally), glabrous laterally; with long, sparse, erect dark setae on wide central area. Posterior $3 / 4$ of labrum coplanar with anteclypeus, inclined at anterior quarter; yellowish-white pubescent, with long, erect dark setae interspersed on coplanar area, anterior margin with fringe of nearly golden pubescence. Gulamentum with transverse, slightly distinct striae on wide posterior area, depressed on narrow anterior area; wide posterior area glabrous, with yellowish-white pubescence on depressed area. Distance between upper eye lobes 0.56 times length of scape; in frontal view, distance between lower eye lobes 0.95 times length of scape. Antennae 1.35 times elytral length, reaching elytral apex at middle of antennomere XI. Scape clavate, slightly sulcate in basal third dorsally; with yellowish-white pubescence (partially lost in the holotype), with orangish-brown pubescence interspersed dorsally. Pedicel with basal and distal pubescent rings, distally distinctly narrower, pubescence mostly pale-yellow dorsally, whiter ventrally. Antennomere III with pale-yellow pubescence on basal quarter of dorsal surface, pubescence whiter on basal half of ventral surface; remaining surface with brown pubescence, with a few white setae interspersed; with a few short, erect dark setae ventrally; remaining antennomeres pale-yellow pubescent on basal half, brown on distal surface; with a few short, erect dark setae on ventral surface of antennomeres IV-X (sparser toward X). Antennal formula (ratio) based on length of antennomere III (only one male measured): scape $=0.77$; pedicel $=0.20 ; \mathrm{IV}=0.72 ; \mathrm{V}=0.52 ; \mathrm{VI}=0.44 ; \mathrm{VII}=0.38$; $\mathrm{VIII}=0.33 ; \mathrm{IX}=0.29 ; \mathrm{X}=0.24 ; \mathrm{XI}=0.25$.

Thorax: Lateral tubercle of prothorax large, conical, slightly inclined upward, with apex blunt. Pronotum with large, elevated tubercle on each side, gradually more elevated anteriorly, becoming nearly conical with apex rounded; with carina-shaped central tubercle, from anterior margin to posterior sulcus, widened posteriorly; coarsely, sparsely punctate around tubercles and anteriorly and posteriorly; with orangish-brown and yellowish-white pubescence intermixed centrally, top of tubercles glabrous, and orangish-brown pubescence with yellowish-white pubescence interspersed (yellowish-white pubescence denser on sides of posterior area and sides of anterior area of lateral tubercles); with a few long, erect dark setae laterally on posterior area. Sides of prothorax coarsely punctate; with yellowish-white pubescence; with orangish-brown pubescence interspersed on area close to pronotum. Ventral surface of thorax with pale-yellow pubescence in some areas partially obscuring integument, distinctly sparser on cen- 
tral area of mesoventrite. Prosternal process 0.7 times as wide as procoxal cavity; lateral margins slightly sinuous. Mesoventral process about as wide as mesocoxal cavity; longitudinally tumid centrally (more elevated toward anterior area), without tubercle on sides of anterior area. Scutellum with orangish-brown pubescence laterally (partially lost in the holotype), yellowish-white centrally. Elytra: Humeri slightly projected forward; with slightly elevated centrobasal crest between humeri and scutellum, covered with small tubercles, and distinct carina from apex of centrobasal crest to near apex; with another carina between humeri and the former carina; both carina fused distally; with small, sparse tubercles on basal quarter; coarsely, sparsely punctate; apex truncate, concave centrally; with yellowish-white and orangish-brown pubescence irregularly mixed, except: white V-shaped band centrally on anterior third (encompassing both elytra); irregular area with brown pubescence between centrobasal crests (pubescence lost in the holotype and most paratypes); oblique brown pubescent band on sides of anterior third dorsally; oblique, large, irregular brown pubescent band dorsally after middle; oblique, moderately large, irregular brown pubescent band dorsally near apex; with pubescent band along suture, from V-shaped pubescent band to apex, with rounded brown pubescent spots interspersed. Legs: Femora with pale-yellow pubescence on some areas partially obscuring integument, forming two dense, longitudinal bands ventrally on base of profemora. Tibiae with three pale-yellow pubescent rings, one basally, one centrally, another at apex; remaining surface with brownish pubescence not obscuring integument. Sides of dorsal surface of protarsomere I and tarsomere $\mathrm{V}$ with pale-yellow pubescence; remaining surface of protarsomere I and protarsomeres II-IV with dark pubescence. Meso- and metatarsi with pale-yellow pubescence dorsally.

Abdomen: Ventrites with dense pale-yellow pubescence laterally, sparser centrally, except glabrous, subrounded macula on each side, near apex in I-IV, near base in $\mathrm{V}$; apex of ventrite $\mathrm{V}$ moderately wide, truncate, centrally emarginate.

Female (Fig. 135): Differs from male by the shorter antennae (1.2 times elytral length, reaching about distal ninth of elytra), and apex of ventrite $\mathrm{V}$ narrower.

Variation: Area between upper eye lobes coarsely, sparsely punctate; pubescence on dorsal surface of scape mostly orangish-brown; elytral apex not centrally concave, with outer angle slightly, triangularly projected.

Dimensions(mm),holotype/paratypemales/paratype females: Total length, 17.80/14.95-18.75/16.75-20.20; prothoracic length, 3.30/2.80-3.40/2.95-3.20; anterior prothoracic width, 4.60/3.80-4.75/4.25-5.00; posterior prothoracic width, 4.70/3.95-4.80/4.40-5.10; maximum prothoracic width, 6.10/5.30-6.30/5.70-6.25; humeral width, 7.25/6.20-7.50/7.05-8.05; elytral length, 12.70/10.30-12.95/12.10-14.05.
Type material: Holotype male from BOLIVIA, Santa Cruz: Andrés Ibáñes (Jardin Botanico), 02-03.XII.2010, J.L. Castro R. Flores col. (FSCA), formerly ACMT). Paratypes BOLIVIA, Santa Cruz: same data as holotype, 2 male, 2 females (MNKM; 1 male, 1 female, ACMT); 4 males, 2 females, same data as holotype except, 26.27.XI.2010, J.L. Castro M. Perez col. (MNKM; 1 male, ACMT; 1 male, 1 female, MZSP); 20 km N Camiri (Road to Eyti; 1250 m; 6-8 km E Hwy 9; 1952'S, 6329'W), 1 female, 05-10.XII.2012, Wappes, Bonaso \& Skillman col. (ACMT); (6-8 km E Hwy 9; $1250 \mathrm{~m}$; $\left.19^{\circ} 52^{\prime} \mathrm{S}, 63^{\circ} 29^{\prime} \mathrm{W}\right), 1$ female, 26.XI.2013, Wappes \& Skillman col. (ACMT); 4 km N Bermejo (Refugio los Volcanes; 1045-1350 m; 18 $\left.06^{\prime} \mathrm{S}, 63^{\circ} 36^{\prime} \mathrm{W}\right), 1$ male, 17-24.X.2014, Wappes \& Morris col. (ACMT).

Remarks: Aegomorphus robustus sp. nov. differs from other species of the genus with a similar appearance (e.g., A. circumflexus) by the mesoventral process distinctly longitudinally tumid centrally, and by lacking anterolateral tubercles (similar species have the mesoventral process flattened or somewhat depressed centrally, and with distinct anterolateral tubercles).

Etymology: This species name "robustus" simply references its robust appearance.

\section{Taxonomic notes in Eupromerella Fisher, 1938; Miriochrus Galileo \& Martins, 2012; and Plagiosaurus Bates, 1880.}

\section{Plagiosaurus Bates, 1880}

\section{Plagiosarus literatus Bates, 1885 (Figs. 136-141)}

Plagiosarus literatus Bates, 1885: 382; Aurivillius, 1923: 383 (cat.); Blackwelder, 1946: 610 (checklist); Gilmour, 1965: 611 (cat.); Chemsak et al., 1992: 132 (cat.); Monné, 1994: 51 (cat.); Monné \& Giesbert, 1994: 237 (checklist); Monné, 2005: 198 (cat.); Hovore, 2006: 376 (distr.); Monné, 2019: 287 (cat.).

Description: Male (Figs. 136-140): Integument mostly black; mouthparts dark reddish-brown except palpomeres black with yellow apex; posterior area of gulamentum dark reddish-brown; anteclypeus, labrum, most of tarsomeres $\mathrm{V}$ reddish-brown; basal half of antennomeres III-IV orangish-brown; basal third of antennomeres V-VIII reddish-brown; femora mostly brown with irregular reddish-brown areas; protibiae with four rings, from base to apex their color is: reddish-brown, dark-brown, reddish-brown, and then black; meso- and metatibiae darkbrown brown with three reddish-brown rings, one basally, one centrally (widest), another at apex (narrowest).

Head: Frons finely, sparsely punctate; with white, pale-yellow and yellowish-brown pubescence intermixed; with a few long, erect dark setae close to eyes. Vertex with punctures as on frons, nearly absent toward 
prothoracic margin; pubescence as on frons between antennal tubercles and upper eye lobes, forming semicircular yellowish-brown macula on each side of median groove close to prothorax. Area behind eyes finely punctate (punctures finer than on frons), denser close to eye, sparser toward prothorax; area behind upper eye lobes with yellowish-brown pubescence; area behind lower eye lobes with pale-yellow pubescence close to eye, with white setae interspersed, wide area close to prothorax glabrous. Genae 1.3 times longer than lower eye lobe; with dense pale-yellow pubescence close to eye, area close to frons glabrous, with sparse pale-yellow pubescence toward glabrous apex, with white setae interspersed. Postclypeus centrally and laterally glabrous, with bristly pale-yellow and yellowish-brown pubescence on remaining surface; with one long dark seta on each side of pubescent area. Posterior $4 / 5$ of labrum coplanar with anteclypeus, inclined at anterior fifth; with pale-yellow pubescence on coplanar area not obscuring integument, inclined area nearly glabrous, distal margin with golden pubescent fringe; with long dark setae directed forward at interface of coplanar and inclined area. Gulamentum smooth, wide posterior area glabrous, depressed, with short yellowish-white setae not obscuring integument anteriorly. Distance between upper eye lobes 0.51 times length of scape; in frontal view, distance between lower eye lobes 0.87 times length of scape. Antennae 1.55 times elytral length, reaching elytral apex at basal third of antennomere IX. Scape clavate, slightly sulcate dorsally at basal third; with dark reddish-brown and brown pubescence intermixed, central pubescent ring with dense, yellowish-brown on outer side, yellowish-white, sparse on remaining surface (sparser dorsally), and narrow pubescent area at apex. Basal ring of pedicel with pale-yellow pubescence, dark-brown pubescence on remaining surface. Antennomere III with yellowish-white pubescence from base to after middle, not obscuring integument, with black pubescence on remaining surface, forming dense tuft of long setae ventrally and on inferior surface of sides; with a few long, erect brownish setae ventrally on light area. Antennomeres IV-X with basal white pubescent ring, and black pubescence on remaining surface; antennomeres IX-XI with erect black setae on distal half of ventral surface. Antennal formula (ratio) based on length of antennomere III (only one female measured): scape $=0.62 ;$ pedicel $=0.24 ; \mathrm{IV}=0.54 ; \mathrm{V}=0.38 ; \mathrm{VI}=0.30$; $\mathrm{VII}=0.25 ; \mathrm{VIII}=0.22 ; \mathrm{IX}=0.21 ; \mathrm{X}=0.12 ; \mathrm{XI}=0.18$.

Thorax: Lateral tubercles of prothorax large, conical, slightly inclined upward, with apex acute. Pronotum with large, elevated tubercle each side of central area, inclined sideways, with apex blunt; central area with elongate tubercle, from anterior margin to posterior sulcus, carina-shaped from anterior margin to near middle, gradually widened from this point to posterior sulcus; coarsely, sparsely punctate between tubercles, anteriorly and posteriorly; central area with yellowish-brown pubescence, except short yellowish-white pubescent band on central tubercle close to anterior margin, and another more irregular one close to posterior margin, six white pubescent irregular macula, one each side of anterior quarter, one each side of posterior third, and one each side of posterior quarter; remaining anterior surface of central tubercle glabrous, and posterior area with brown pubescence not obscuring integument; apex of lateral tubercles glabrous; with dark-brown pubescent band close to outer side of lateral tubercles, and remaining dorsal surface of lateral tubercles on prothorax with yellowish-brown, pale-yellow and white pubescence intermixed; with a few long, erect dark setae laterally in posterior area. Sides of prothorax coarsely, sparsely punctate; with yellowish-brown pubescence and white pubescence interspersed. Prosternum with moderately dense yellowish-brown pubescence laterally, gradually whiter, distinctly sparser centrally, anterior area glabrous. Prosternal process slightly wider than half width of procoxal cavity; with sparse white pubescence. Ventral surface of mesothorax with dense abundant yellowish-brown pubescence laterally, white, notably sparse on central area of mesoventrite, white and sparse on mesoventral process. Mesoventral process slightly wider than width of mesocoxal cavity; with small tubercle each side of anterior area. Ventral surface of metathorax with abundant yellowish-brown pubescence laterally, whiter, sparser centrally. Scutellum with yellowish-white pubescence centrally, dark brown laterally. Elytra: Humeri very slightly projected forward; centrobasal crest short, elevated, covered with small tubercles; with slightly distinct carina from apex of centrobasal crest to posterior quarter, and another between the first and the humeri; apex truncate, with outer angle triangularly projected; coarsely, sparsely punctate on basal quarter, gradually finer, sparser toward apex; with abundant yellowish-brown pubescence with irregular white maculae interspersed, and three black pubescent dorsal areas, one at anterior third, one about middle, another at posterior quarter; with white pubescent band along suture, with small black pubescent maculae interspersed; with long, erect, sparse dark setae on basal quarter, especially on centrobasal crest. Legs: Femora with abundant yellowish-brown and pale-yellow pubescence intermixed, not obscuring integument. Protibiae with pale-yellow pubescence on anterior $2 / 3$ not obscuring integument, black on distal third; with sparse, long, erect black setae interspersed. Meso- and metatibiae with pale-yellow pubescence on light areas (partially white on distal light ring), dark brown on dark areas. Protarsomeres I-IV with black pubescence, white pubescence interspersed on sides of I; protarsomere $\mathrm{V}$ mostly with white pubescence. Meso- and metatarsomeres I and most of $V$ with white pubescence; tarsomeres II and IV with black pubescence; tarsomeres III, partially with black pubescence and white pubescence interspersed.

Abdomen: Ventrites I-IV with abundant yellowish-brown pubescence laterally, gradually whiter, sparser centrally; ventrite $\mathrm{V}$ with sparse yellowish-brown pubescence, slightly whiter centrally; ventrite $\mathrm{V}$ with apex concave.

Dimensions (mm), male (1)/female (2): Total length, 8.90/9.70-12.10; prothoracic length, 1.70/1.75-2.10; ante- 
rior prothoracic width, 2.10/2.30-2.80; posterior prothoracic width, 2.20/2.40-2.90; maximum prothoracic width, 2.85/3.25-3.80; humeral width, 3.40/3.70-4.50; elytral length, 5.65/6.40-7.70.

Material examined: MEXICO, Veracruz: Los Tuxtlas (UNAM), 1 male, 05-06.V.1994, J.E. Wappes col. (ACMT); $15 \mathrm{~km}$ W Sontecomapan, 2 females, 10-13.IV.1993, J.E. Wappes col. (ACMT; MZSP).

Known geographical distribution (Monné, 2019; Tavakilian \& Chevillotte, 2019): Mexico (Veracruz), Guatemala.

Remarks: Plagiosarus literatus was originally described base on a single female from Guatemala with Monné \& Giesbert (1994) subsequently listing the species from Mexico (Veracruz). Recently, the species has only been mentioned in catalogs and checklists and until now the male had never been described.

\section{Eupromerella Fisher, 1938}

\section{Eupromerella inaequalis (Galileo \& Martins, 2011), comb. nov.}

Psapharochrus inaequalis Galileo \& Martins, 2011: 177; Wappes \& Arias, 2016: 8 (holotype); Monné, 2019: 296 (cat.).

Galileo \& Martins (2011) described Psapharochrus inaequalis based on a single male from Bolivia. According to Martins \& Santos-Silva (2013): "The main feature that allows the separation of Eupromerella from Psapharochrus is the shorter body when the proportion between the head and prothorax is compared with the elytra. No other reliable character can be used to distinguish these genera. The main problem is that there are currently several different forms placed in Psapharochrus. However, this does not prevent the transfer of species from Psapharochrus to Eupromerella and does not classify it as a doubtful genus."

Psapharochrus inaequalis is nearly identical to Eupromerella orbifera (Aurivillius, 1908). The latter species was originally described in Psapharochrus and transferred to Eupromerella Fisher, 1938 by Monné \& Giesbert (1994). In reality, E. orbifera is a problematic species that could be included in either Psapharochrus (now Aegomorphus) or Eupromerella. Also, it is probable that $P$. inaequalis may only be a variation of $E$. orbifera, a species that also occurs in Bolivia. For now, it will be kept as a different species because the apex of the protibiae is entirely dark (only apex in the holotype and specimens examined), and its elytral pubescence slightly sparser (but with same pattern). It will be necessary to examine the holotype before a synonymy could be considered.

Known geographical distribution (Monné, 2019; Tavakilian \& Chevillotte, 2019): Bolivia (Santa Cruz).

\section{Eupromerella quadrituberculata (Zajciw, 1964), comb. nov. \\ (Figs. 142-146)}

Acanthoderes quadrituberculata Zajciw, 1964: 160, 1969a: 198 (distr.), 1974: 67 (distr.); Julio et al., 2000: 31 (holotype).

Acanthoderes (Psapharochrus) quadrituberculata; Zajciw, 1969b: 608; Monné, 1994: 67 (cat.); Monné \& Giesbert, 1994: 231 (checklist).

Psapharochrus quadrituberculatus; Monné, 2005: 212 (cat.); Monné \& Monné, 2016: 57 (holotype); Monné, 2019: 304 (cat.).

The eyes of Acanthoderes quadrituberculata (Fig. 146) are not distinctly finely granulated hence its inclusion in this genus is incorrect. Furthermore, its general shape indicates that it is much better placed in Eupromerella than in Aegomorphus (see comments in Eupromerella inaequalis).

Unfortunately, both the holotype and all paratypes were destroyed during the 2018 fire in the MNRJ.

Material examined: BRAZIL, Espírito Santo: Parque Sooretama, 2 males, 27.XI.1967, F. Oliveira col. (MZSP).

Known geographical distribution (Monné, 2019; Tavakilian \& Chevillotte, 2019): Brazil (Espírito Santo).

\section{Eupromerella boliviana sp. nov. (Figs. 147-151)}

Description: Female: Integument mostly black; mouthparts dark reddish-brown, except palpi black with reddish-brown apex of last palpomeres; antennomere III brown on basal $2 / 3$, black on distal third (slightly reddish-brown on apical area); remaining antennomeres yellowish-brown on basal half/third, black on remaining surface; anteclypeus and labrum mostly testaceous.

Head: Frons finely, densely punctate; with yellowish-brown and pale-yellow pubescence intermixed, nearly obscuring integument, with yellowish-white setae interspersed, large yellowish-white pubescent macula between eyes and antennal tubercles centrally. Vertex finely, abundantly punctate; area between antennal tubercles with yellowish-white pubescence not obscuring integument centrally, with yellowish-white setae interspersed, and dense yellowish-white pubescence laterally; area between upper eye lobes and beginning of area behind upper eye lobes with yellowish-white pubescence not obscuring integument, with yellowish-brown setae interspersed, dense yellowish-brown pubescence on remaining surface, except brown pubescent macula between the two pubescent areas; area close to prothorax nearly glabrous; remaining surface area behind upper eye lobes close to eye with yellowish-brown and brown pubescence not obscuring integument, glabrous toward prothorax. Area behind lower eye lobes with sparse yellowish-white pubescence close to superior area of 
eye, denser toward ventral surface, distinctly sparser toward prothorax. Genae about as long as lower eye lobe; with yellowish-brown pubescence, denser close to eye, sparser on remaining surface. Postclypeus with bristly yellowish-brown pubescence on wide central area not obscuring integument, central area nearly glabrous laterally glabrous. Posterior $3 / 4$ of labrum coplanar with anteclypeus, inclined on anterior quarter; with abundant yellowish-white pubescence on coplanar area, becoming yellowish toward anterior margin. Gulamentum glabrous except narrow anterior area with yellowish-white pubescence not obscuring integument. Distance between upper eye lobes 0.73 times length of scape; in frontal view, distance between lower eye lobes 1.17 times length of scape. Antennae 1.6 times elytral length, reaching elytral apex at basal third of antennomere IX. Scape nearly straight at outer surface, strongly, gradually widened from base to middle of inner surface, then slightly narrowed toward apex; with yellowish-brown and brown pubescence mixed dorsally, not obscuring integument, except dense, narrow yellowish pubescent macula on apex; with yellowish-white pubescence not obscuring integument on remaining surface. Pedicel brown pubescent dorsally, with yellowish-brown pubescence interspersed, especially basally; remaining surface with yellowish-white pubescence not obscuring integument. Light area of antennomeres with yellowish-white pubescence (sparser on some areas of III), and dark brown pubescence on dark area; ventral surface of antennomeres III-IV with short, sparse, erect yellowish-brown setae; apex of antennomeres $\mathrm{V}-\mathrm{X}$ with short, erect, brownish setae at apex. Antennal formula (ratio) based on length of antennomere III: scape $=0.78$; pedicel $=0.24 ; \mathrm{IV}=0.87 ; \mathrm{V}=0.58$; $\mathrm{VI}=0.51 ; \mathrm{VII}=0.42 ; \mathrm{VIII}=0.37 ; \mathrm{IX}=0.36 ; \mathrm{X}=0.31 ; \mathrm{XI}=0.33$.

Thorax: Lateral tubercle of prothorax large, conical, slightly curved upward, with apex nearly acute. Pronotum with large gibbosity on each side of central area, and slightly elevated central gibbosity on posterior half, becoming carina-shaped on anterior half; coarsely, densely punctate, except smooth posterior area of central gibbosity; with irregular tufts of light yellowish-brown pubescence (more pale yellow posteriorly), and moderately spare brown pubescence between them, except glabrous posterior area of central gibbosity; with a few long, erect dark setae on sides of posterior area. Sides of prothorax coarsely, abundantly punctate; with light yellowish-brown pubescence throughout. Ventral surface of thorax with moderately dense pale-yellow pubescence laterally, gradually sparser, whiter centrally. Narrowest area of prosternal process slightly less than half width of procoxal cavity. Apex of mesoventral process about as wide as mesocoxal cavity. Scutellum with short brownish pubescence not obscuring integument, with yellowish-brown setae interspersed. Elytra: Coarsely, abundantly punctate on basal third, punctures gradually sparser on remaining surface toward apex; apex obliquely truncate; with dense light yellowish-brown pubescence nearly entirely obscuring integument, except: irregular, narrow, fragmented
V-shaped (across both elytra) brownish pubescent area on center of basal third; small, irregular white pubescent spot on base of each arm of V-shaped area; large, irregular white pubescent macula dorsally on basal half; irregular, nearly triangular brown pubescent macula dorsally after middle, laterally margined with narrow, white pubescence, especially on outside edge; irregular, white pubescent macula dorsally on posterior quarter close to latter dark macula; small, irregular white pubescent spot near apex; narrow white pubescent macula along suture and epipleural margin (nearly absent on basal quarter of sutural area), with brown pubescent areas interspersed. Legs: Femora with yellowish-white pubescence on peduncle and basal area of club, remaining surface densely pale-yellow. Tibiae with yellowish-white pubescence, except two brown pubescent macula covering dorsal area and sides, one less conspicuous on basal third, another wider on posterior half (more conspicuous in protibiae). Tarsomeres I and V with yellowish-white pubescence dorsally (sparser on protarsomere I); tarsomeres II-IV with brown pubescence dorsally.

Abdomen: Ventrites with yellowish-white pubescence not obscuring integument, slightly yellower and denser on $\mathrm{V}$; ventrite $\mathrm{V}$ centrally sulcate at basal third; apex of ventrite $\mathrm{V}$ truncate.

Dimensions ( $\mathrm{mm}$ ), holotype female/paratype female: Total length, 6.30/6.25; prothoracic length, 1.25/1.20; anterior prothoracic width, 1.80/1.80; posterior prothoracic width, 1.80/1.80; maximum prothoracic width, 2.40/2.30; humeral width, 2.85/2.80; elytral length, 4.50/4.35.

Type material: Holotype female from BOLIVIA, Santa Cruz: Potrerillo del Guendá (Reserva Natural, Snake Farm; $\left.400 \mathrm{~m} ; 1^{\circ} 40^{\prime} 15^{\prime \prime} \mathrm{S}, 63^{\circ} 27^{\prime} 26^{\prime \prime} \mathrm{W}\right), 23-30 . X .2013$, Wappes \& Kuckartz col. (FSCA, formerly ACMT). Paratype female from BOLIVIA, Santa Cruz: Andrés Ibáñes (Potrerillo del Guendá; $\left.370 \mathrm{~m} ; 17^{\circ} 40^{\prime} \mathrm{S}, 63^{\circ} 27^{\prime} \mathrm{W}\right), 23-27 . X .2007$, S.W. Lingafelter col. (SWLC).

Remarks: Eupromerella boliviana sp. nov. is similar to E. plaumanni (Fuchs, 1959) but females differ as follows: size smaller; lower eye lobes proportionally smaller; femoral peduncle shorter; elytral pubescent pattern with posterior dark macula not arch-shaped; and metaventrite not punctate laterally. Females of E. plaumanni are larger, lower eye lobes are proportionally larger, femoral peduncle are longer, posterior dark macula of the elytra is arch-shaped, and the metaventrite is punctate laterally. The new species differs from E. picturata Martins, Galileo \& Limeira-de-Oliveira, 2009 (females) by the smaller size, metaventrite not punctate laterally (punctate in E. picturata), the pubescence of the scape is sparser (denser in E. picturata), and posterior dark macula of the elytra not arch-shaped (arched in E. picturata). Eupromerella boliviana also differs from E. propinqua (Melzer, 1931), and E. pseudopropinqua (Fuchs, 1959), by the different pubescent pattern of the elytra (see photographs of the types of those two species at Bezark, 2019). 
Etymology: This species is named "boliviana" after the country (Bolivia) where it is found.

\section{Miriochrus Galileo \& Martins, 2012}

Miriochrus Galileo \& Martins, 2012: 66; Monné, 2019: 256 (cat.).

Miriochrus was described to include $M$. minimus Galileo \& Martins, 2012 from Paraguay (see photograph of the holotype at Bezark, 2019). In the original description, the genus was compared to Nesozineus Linsley \& Chemsak, 1996 (translated): "Miriochrus gen. nov. by the pronotum lacking tubercles, and by the small dimensions, resembles Nesozineus Linsley \& Chemsak, 1966, but differs by the eye lobes nearly divided (one ommatidium in the narrowest area between the lobes), scape piriform, short elytra with 1.5 times the humeral width, and presence of white seta inside of the elytral punctures. In Nesozineus, the eye lobes are separated between them by three or four rows of ommatidia, the scape is subcylindrical, the elytra are longer, with more than 1.5 times humeral width, and the elytral punctures have no white seta." Actually, Miriochrus is much more similar to Eupromerella Fisher, 1938, and primarily differs by the presence of white seta inside its elytral punctures, which are absent in Eupromerella. This feature is also shared with the Plistonax Thomson, 1864, and Melzerus Monné, 2005. The species of Plistonax are slenderer, and the apex of the prothoracic tubercles is blunt (acute in Miriochrus); Melzerus has a distinct cavity in the ventral surface of the femora of males, which are absent in males of Miriochrus, and the apex of the prothoracic tubercles is rounded.

The following list of Acanthoderini genera and species reflects the taxonomic changes made based on the results of our studies. It also indicates the type of change made, such as: syn. nov., comb. nov., nomen protectum, nomen oblitum, sp. nov. and revalidation or resurrection, as appropriate.

\section{Aegomorphus Haldeman, 1847. American species.}

$=$ Psapharochrus Thomson, 1864 syn. nov.

Aegomorphus albosignus Chemsak \& Noguera, 1995

Aegomorphus arietis (Bates, 1885) comb. nov.

Aegomorphus arizonicus Linsley \& Chemsak, 1984

Aegomorphus auratus (Garcia \& Nascimento, 2019) comb. nov.

Aegomorphus atrosignatus (Melzer, 1932) comb. nov.

Aegomorphus bezarki (Santos-Silva \& Galileo, 2016) comb. nov.

Aegomorphus bicuspis (Germar, 1823) comb. nov.

Aegomorphus bimaculatus (Fuchs, 1958) comb. nov.

Aegomorphus binocularis (Martins, 1981) comb. nov.

Aegomorphus bivittus (White, 1855) comb. nov.

Aegomorphus borrei (Dugés, 1885) comb. nov.

Aegomorphus chamelae Chemsak \& Giesbert, 1986

Aegomorphus brevicornis (Zajciw, 1964) comb. nov.

Aegomorphus brunnescens (Zajciw, 1963) comb. nov.

Aegomorphus carinicollis (Bates, 1880) comb. nov.

Aegomorphus cerdai (Tavakilian \& Néouze, 2013) comb. nov.
Aegomorphus chrysopus (Bates, 1861) comb. nov.

Aegomorphus circumflexus (Jacquelin DuVal, 1857) nomem protectum, comb. nov.

$=$ Acanthocinus rusticus Klug, 1829 nomen oblitum

= Psapharochrus histrio Casey, 1913 syn. nov.

= Psapharochrus guatemalensis Casey, 1913 syn. nov.

Aegomorphus clericus (Bates, 1880) comb. nov.

Aegomorphus comptus (Marinoni \& Martins, 1978) comb. nov.

Aegomorphus coniferus (Zajiciw, 1963) comb. nov.

Aegomorphus consentaneus (Thomson, 1865) comb. nov.

Aegomorphus contaminatus (Thomson, 1965) revalidat., comb. nov.

Aegomorphus corticarius (Tippmann, 1960) comb. nov.

Aegomorphus crocostigma (Bates, 1880) comb. nov.

Aegomorphus cylindricus (Bates, 1861) comb. nov.

Aegomorphus doctus (Bates, 1880) comb. nov.

Aegomorphus excellens (Zajiciw, 1964) comb. nov.

Aegomorphus flavitarsis (Fuchs, 1962) comb. nov.

Aegomorphus galapagoensis galapagoensis (Linell, 1898) comb. nov.

Aegomorphus galapagoensis vonhageni (Mutchler, 1938) comb. nov.

Aegomorphus galapagoensis williamsi (Linsley \& Chemsak, 1966) comb. nov.

Aegomorphus geminus (Galileo \& Martins, 2012) comb. nov.

Aegomorphus gigas (Galileo \& Martins, 2012) comb. nov.

Aegomorphus hebes (Bates, 1861) comb. nov.

Aegomorphus homonymus (Blackwelder, 1946) comb. nov.

Aegomorphus inquinatus (Bates, 1872) comb. nov.

Aegomorphus irumus (Galileo \& Martins, 2011) comb. nov.

Aegomorphus itatiayensis (Melzer, 1935) comb. nov.

Aegomorphus jaspideus (Germar, 1823) comb. nov.

Aegomorphus juno (Fisher, 1938) comb. nov.

Aegomorphus laetificus (Bates, 1880) comb. nov.

Aegomorphus lanei (Marinoni \& Martins, 1978) comb. nov.

Aegomorphus langeri (Martins, Santos-Silva \& Galileo, 2015) comb. nov.

Aegomorphus lateralis (Bates, 1861) comb. nov.

Aegomorphus lengii (Wickham, 1914) comb. nov.

Aegomorphus leucodryas (Bates, 1880) comb. nov.

Aegomorphus longipennis (Zajciw, 1963) comb. nov.

Aegomorphus longispinis (Bates, 1861) comb. nov.

Aegomorphus longitarsis (Bates, 1880) comb. nov.

Aegomorphus lotor (White, 1855) comb. nov.

Aegomorphus luctuosus (Bates, 1880) comb. nov.

Aegomorphus maccartyi (Chemsak \& Hovore, 2002) comb. nov.

Aegomorphus maculatissimus (Bates, 1861) comb. nov.

Aegomorphus magnus (Marinoni \& Martins, 1978) comb. nov.

Aegomorphus meleagris (Bates, 1861) comb. nov.

Aegomorphus mexicanus Martins, Santos-Silva \& Galileo, 2015

Aegomorphus modestus (Gyllenhal, 1817)

Aegomorphus morrisii (Uhler, 1855)

Aegomorphus mourei (Zajciw, 1964) comb. nov.

Aegomorphus nearnsi (Martins \& Galileo, 2010) comb. nov.

Aegomorphus nigricans (Lameere, 1884) comb. nov.

Aegomorphus nigromaculatus (Fuchs, 1958) comb. nov.

Aegomorphus nigropunctatus (Tippmann, 1960) comb. nov.

Aegomorphus nigrovittatus (Zajiciw, 1969) comb. nov.

Aegomorphus pantherinus (Tavakilian \& Néouze, 2013) comb. nov.

Aegomorphus peninsularis (Horn, 1880)

Aegomorphus penrosei Chemsak \& Hovore, 2002

Aegomorphus pereirai (Prosen \& Lane, 1955) comb. nov.

Aegomorphus peritapnioides (Linsley, 1958) comb. nov.

Aegomorphus phasianus (Bates, 1861) comb. nov.

Aegomorphus pictus (Galileo \& Martins, 2012) comb. nov.

Aegomorphus pigmentatus (Bates, 1861) comb. nov. 
Aegomorphus pinima (Galileo \& Martins, 2006) comb. nov.

Aegomorphus piperatus (Gahan, 1892) comb. nov.

Aegomorphus piraiuba (Martins \& Galileo, 2003) comb. nov.

Aegomorphus polystictus (Bates, 1885) comb. nov.

Aegomorphus pseudosatellinus (Tavakilian \& Néouze, 2013) comb. nov.

Aegomorphus pupillatus (Bates, 1880) comb. nov.

Aegomorphus purulensis (Bates, 1885) comb. nov.

Aegomorphus quadrigibbus (Say, 1831) comb. nov.

Aegomorphus ramirezi (Chemsak \& Hovore, 2002) comb. nov.

Aegomorphus ridleyi (Waterhouse, 1890) comb. nov.

Aegomorphus rileyi (Tavakilian \& Néouze, 2013) comb. nov.

Aegomorphus robustus sp. nov.

Aegomorphus rufitarsis (Kirsch, 1889) comb. nov.

Aegomorphus satellinus (Erichson, 1847) comb. nov.

Aegomorphus schmithi (Melzer, 1935) comb. nov.

Aegomorphus signatifrons (Zajciw, 1964) comb. nov.

Aegomorphus signatus (Gahan, 1892) comb. nov.

Aegomorphus socorroensis (Linsley, 1942) comb. nov.

Aegomorphus travassosi (Monné \& Magno, 1992) comb. nov.

Aegomorphus umbratus (Bates, 1885) comb. nov.

Aegomorphus vetustus (Bates, 1880) comb. nov.

Aegomorphus wappesi (Galileo, Martins \& Santos-Silva, 2015) comb. nov.

=Psapharochrus jameswappesi Tavakilian, 2018 syn. nov.

\section{Eupromerella Fisher, 1938}

Eupromerella boliviana sp. nov.

Eupromerella clavator (Fabricius, 1801)

Eupromerella fuscicollis (Bates, 1861)

Eupromerella gallardi Tavakilian \& Néouze, 2013

Eupromerella griseofasciata (Fuchs, 1958)

Eupromerella inaequalis (Galileo \& Martins, 2011) comb. nov.

Eupromerella leucogaea (Erichson, 1847)

Eupromerella maculata Martins, Galileo \& Limeira-de-Oliveira, 2009

Eupromerella minima (Bates, 1861)

Eupromerella nigroapicalis (Aurivillius, 1916)

Eupromerella nigroocellata (Tippmann, 1960)

Eupromerella orbifera (Aurivillius, 1908)

Eupromerella picturata Martins, Galileo \& Limeira-de-Oliveira, 2009

Eupromerella plaumanni (Fuchs, 1958)

Eupromerella propinqua (Melzer, 1931)

Eupromerella pseudopropinqua (Fuchs, 1958)

Eupromerella quadrituberculata (Zajciw, 1964) comb. nov.

Eupromerella semigrisea (Bates, 1861)

Eupromerella travassosi (Melzer, 1935)

Eupromerella versicolor (Melzer, 1935)

\section{Scythropopsis Thomson, 1864 resurrection of the original status}

Scythropopsis abstersa (Bates, 1880)

Scythropopsis albitarsis (Laporte, 1840)

Scythropopsis barrerai (Chemsak \& Hovore, 2002) comb. nov.

Scythropopsis boucheri Tavakilian \& Néouze, 2013

Scythropopsis cornuta (Bates, 1880) comb. nov.

Scythropopsis intricata sp. nov.

Scythropopsis lacrymans (Thomson, 1865) comb. nov.

Scythropopsis lugens (Thomson, 1865) comb. nov.

Scythropopsis melanostictica (White, 1855) comb. nov.

$=$ Pteridotelus contaminatus Thomson, 1865 syn. nov.
Scythropopsis nigritarsis (White, 1855) comb. nov.

Scythropopsis pupillata (Bates, 1880)

Scythropopsis sallei (Thomson, 1865) comb. nov.

Scythropopsis wappesi (Chemsak \& Hovore, 2002) comb. nov.

\section{Symperasmus Thomson, 1864 resurrection of the original status}

\section{Symperasmus affinis (Thomson, 1865)}

Symperasmus alboniger (Bates, 1861) comb. nov.

= Acanthoderes (Psapharochrus) albomaculatus Fuchs, 1963 syn. nov.

$=$ Acanthoderes griseomaculata Zajiciw, 1971 syn. nov.

Symperasmus thoracicus (White, 1855) comb. nov.

\section{ACKNOWLEDGMENTS}

Special thanks to the individuals who loaned specimens from their collections, or those in their care, for inclusion in this study. They include Kyle Schnepp and Paul Skelley (FSCA), Steven W. Lingafelter, Roy F. Morris and Fred W. Skillman. The second author is grateful to the"Fundação de Amparo à Pesquisa do Estado de São Paulo" (FAPESP) for a postdoctoral fellowship (process number 2017/17898-0).

\section{REFERENCES}

Alexander, D.R. 1958. A preliminary survey of the Cerambycids (Insecta: Coleoptera) of Oklahoma. Proceedings of the Oklahoma Academy of Sciences, 38: 43-52.

Audinet-Serville, J.G. 1835. Nouvelle classification de la famille des longicornes. (suite). Annales de la Société Entomologique de France, 4(1): 5-100.

Audureau, A. 2008. Contribution a la connaissance des Cerambycidae de la reserve privée forestière de Domitila (Nicaragua). Lambillionea Supplement, 108(3): 3-20.

Audureau, A. 2010. Complément a l'inventaire faunistique des Cerambycidae de la reserve privée forestière de Domitila (Nicaragua) aves description de nouvelles espèces (Coleoptera, Cerambycidae). Les Cahiers Magellanes, 110: $1-10$.

Audureau, A. \& Roguet, J.P. 2018. Contribution à la connaissance des Cerambycidae de la région nord du Nicaragua (Coleoptera, (erambycidae). Les Cahiers Magellanes (N.S.), 30: 56-104.

Aurivillius, C. 1923. Coleopterorum Catalogus, pars 74, Cerambycidae: Lamiinae. Berlin, W. Junk. p. 323-704.

Bates, H.W. 1861. Contributions to an insect fauna of the Amazon Valley. Coleoptera: Longicornes. The Annals and Magazine of Natural History, Série 3, 8(23): 212-219.

Bates, H.W. 1872. On the longicorn Coleoptera of Chontales, Nicaragua. The Transactions of the Entomological Society of London, 1872: 163-238.

Bates, H.W. 1880. Biologia Centrali-Americana, Insecta, Coleoptera. London. v. 5, p. 17-152.

Bates, H.W. 1885. Biologia Centrali-Americana, Insecta, Coleoptera, suppl. to Longicornia. London. v. 5, p. 249-436.

Beal, J.A. \& Massey, C.L. 1945. Bark beetles and ambrosia beetles (Coleoptera, Scolytoidea) with special reference to species occurring in North Carolina. Bulletin of the Duke University School of Forestry, 10: 1-178.

Beaulne, J.I. 1932. Longicornes nuisibles aux végétaux ligneux du Canada. Naturaliste Canadien, 59(11): 219-222. 
Berry, P.A. \& Salazar-Vaquero, M. 1957. Lista de insectos clasificados de El Salvador. Boletín Técnico del Ministerio de Agricultura y Ganaderia, 21: 1-134.

Beutenmuller, W. 1896. Food habits of North American Cerambycidae. Journal of the New York Entomological Society, 4: 73-81.

Bezark, L.G. 2019. A photographic Catalog of the Cerambycidae of the New World. Available at: https://apps2.cdfa.ca.gov/publicApps/plant/ bycidDB/wsearch.asp?w=n. Access in: 02/2019.

Blackwelder, R.E. 1946. Checklist of the coleopterous insects of Mexico, Central America, the West Indies and South America. Part 4. Bulletin of the United States National Museum, 185: 551-763.

Bland, J.H.B. 1861. Catalogue of the longicorn Coleoptera taken at the vicinity of Philadelphia. Proceedings of the Entomological Society of Philadelphia, 1: 93-101.

Blatchley, W.S. 1910. On the Coleoptera known to occur in Indiana. An illustrated descriptive catalogue of the Coleoptera or beetles (exclusive of the Rhynchophora) known to occur in Indiana. Bulletin of the Indiana Department of Geology and Natural Resources, 1: 1-1386.

Brimley, C.S. 1938. The insects of North Carolina, being a list of the insects of North Carolina and their close relations. Raleigh, North Carolina Department of Agriculture, Division of Entomology. 560p.

Buck, P. 1959. Cerambycidae in der Sammlung des Instituto Anchietano de Pesquisas. Pesquisas, Porto Alegre, 3: 577-609.

Casey, T.L. 1913. Further studies amongst the American Longicornia. In: Cassey, T.L. Memoirs on the Coleoptera. Lancaster, PA., The New Era Printing Co. v. 4, p. 193-388.

Caulfield, F.B. 1890. Insects injurious to the oak. Annual Report of the Entomological Society of Ontario, 1889: 55-66.

Champlain, A.B.; Kirk, H.B. \& Knull, J.N. 1925. Notes on Cerambycidae. Entomological News, 36(5): 139-142.

Chemsak, J.A. 1969. Records and descriptions of Cuban Cerambycidae (Coleoptera). Acta Musei Moraviensis, 54: 185-190.

Chemsak, J.A. 1977. A list of types of Cerambycidae at the Field Museum of Natural History, Chicago (Coleoptera). The Coleopterists Bulletin, 31(2): 173-179.

Chemsak, J.A. \& Hovore, F.T. 2002a. New Mexican and Central American species of Acanthoderini with notes on others, Part I. (Coleoptera, Cerambycidae, Lamiinae). Les Cahiers Magellanes, 15: 1-32.

Chemsak, J.A. \& Hovore, F.T. 2002b. New Mexican and Central American species of Acanthoderini with notes on others, Part II (continued). (Coleoptera, Cerambycidae, Lamiinae). Les Cahiers Magellanes, 16: 1-26.

Chemsak, J.A. \& Linsley, E.G. 1980. Records of Cerambycidae from Cocos Islands (Coleoptera). The Pan-Pacific Entomologist, 56(4): 310.

Chemsak, J.A. \& Noguera, F.A. 1995. Annotated checklist of the Cerambycidae of the Estación de Biologia Chamela, Jalisco, Mexico (Coleoptera), with descriptions of a new genera and species. Folia Entomologica Mexicana, 89: 55-102.

Chemsak, J.A.; Linsley, E.G. \& Mankins, J.V. 1980. Records of some Cerambycidae from Honduras (Coleoptera). The Pan-Pacific Entomologist, 56(1): 26-37.

Chemsak, J.A.; Linsley, E.G. \& Noguera, F.A. 1992. Listados faunísticos de México. II. Los Cerambycidae y Disteniidae de Norteamérica, Centroamérica y las Indias Occidentales (Coleoptera). México, D.F., Universidad Nacional Autónoma. 204p.

Chevrolat, L.A. 1862. Coléoptères de I'lle de Cuba. Notes, synonymies et descriptions d'espèces nouvelles. Familles des cérambycides et des parandrides. Annales de la Société Entomologique de France, (4)2: 245-280.

Chittenden, F.H. 1894. On the habits of some longicorns. Proceedings of the Entomological Society of Washington, 3(2): 95-102.

Craighead, F.C. 1923. North American cerambycid larvae. Bulletin of the Canada Department of Agriculture (n.s.), 27: 1-239.
Dejean, P.F.M.A. 1835. Catalogue des Coléopteres de la collection de M. le Comte Dejean. Livraison 4. Promecops. Paris, Méquignon-Marvis. p. 257-360.

Dejean, P.F.M.A. 1835. Catalogue des coléopteres de la collection de M. le comte Dejean. Troisieme édition, revue, corrigée et augmentée. Livraisons 1-5. Paris, Méquignon-Marvis Pere et Fils. $442 \mathrm{p}$.

Duffy, E.A.J. 1960. A monograph of the immature stages of Neotropical timber beetles (Cerambycidae). London, British Museum (Natural History). 327p.

Dury, C. 1902. A revised list of the Coleoptera observed near Cincinnati, Ohio, with notes on localities, bibliographical references and descriptions of six new species. Journal of the Cincinnati Society of Natural History, 20: 107-196.

Erichson, W.F. 1847. Conspectus insectorum coleopterorum quae in Republica Peruana observata sunt. Archiv für Naturgeschichte, 13: 67-185.

Fattig, P.W. 1947. The Cerambycidae or long-horned beetles of Georgia. Emory University Museum Bulletin, 5: 1-48.

Felt, E.P. 1906. Insects affecting park and woodland trees. Memoirs of the New York State Museum, 8: 1-877.

Fernández García, I.; Favila Castillo, M.E. \& López Iborra, G. 2009. Coleópteros (Insecta, Coleoptera) del área protegida de recursos manejados Mil Cumbres, Sierra del Rosário, Cuba. Boletin Sociedad Entomológica Aragonesa, 45: 317-325.

Fisher, W.S. 1944. Cerambycidae (Coleoptera) of Caripito, Venezuela. Zoologica, 29(1): 3-12.

Fisher, W.S. \& Kirk, H.B. 1912. Cerambycidae of Harrisburg, Pennsylvania and vicinity with notes. Entomological News, 23: 308-316.

Franz, E. 1954. Cerambycidae (Ins., Col.) aus El Salvador. Senckenbergiana, 34(4-6): 213-229.

Fuchs, E. 1963. 5. Beitrag zur Kenntnis der neotropischen Cerambyciden. Koleopterologische Rundschau, 40/41: 10-16.

Gahan, C.J. 1892. Additions to the Longicornia of Mexico and Central America, with notes on some previously recorded species. The Transactions of the Entomological Society of London, 1892: 255-274.

Gahan, C.J. 1895. On the longicorn Coleoptera of the West Indian islands. The Transactions of the Entomological Society of London, 1895: 79-140.

Galileo, M.H.M. \& Martins, U.R. 2011. Novas espécies de Acanthoderini, Onciderini e Pteropliini (Coleoptera, Cerambycidae, Lamiinae) do Brasil e da Bolívia. Acta Amazonica, 41(1): 175-182.

Galileo, M.H.M. \& Martins, U.R. 2012. Novos táxons e nova sinonimia em Acanthoderini neotropicais (Cerambycidae, Lamiinae). Les Cahiers Magellanes (N.S.), 7:61-69.

Galileo, M.H.M.; Martins, U.R. \& Santos-Silva, A. 2015. Five new Lamiinae (Coleoptera, Cerambycidae) from Bolivia in honor of James E. Wappes. ZooKeys, 488: 77-89.

García Morales, L.J.; García Jiménez, J.; Toledo, V.H. \& Cantú Ayala, C.M. 2014. Lista anotada preliminar de los Cerambycidae (Coleoptera) de Tamaulipas, México. Biodiversidade Tamaulipeca, Instituto Tecnológico de Ciudad Victoria, 2(2): 97-115.

Gemminger, M. 1873. In: Gemminger, M. \& Harold, E. Catalogus Coleopterorum hucusque descriptorum synonymicus et systematicus. Monachii, Gummi. v. 10, p. 2989-3232.

Gilmour, E.F. 1965. Catalogue des Lamiaires du Monde (Col., Cerambycidae). Museum G. Frey, Tutzing bei München, 8: 559-655.

Gilmour, E.F. 1968. The Coleoptera Cerambycidae of Curaçao, Aruba and Bonaire. Studies on the Fauna of Curaçao, 25(100): 83-178.

Gistel, J.N.F. 1857. Achthunfert und zwanzig neue oder unbeschriebene wirbellose Thiere. Straubing, $94 \mathrm{p}$.

Gregoire, C. 1957. Studies by phase-contrast microscopy on distribution of patterns of hemolymph coagulation in insects. Smithsonian Miscellaneous Collections, 134(6): 1-5.

Gundlach, J. 1891. Contribución a la entomologia cubana. La Habana, 3: 1-494. 
Haldeman, S.S. 1847. Material towards a history of the Coleoptera Longicornia of the United States. Transactions of the American Philosophical Society, 10: 27-66.

Hamilton, J. 1895. Catalogue of the Coleoptera of southwestern Pennsylvania, with notes and descriptions. Transactions of the American Entomological Society, 22: 317-381.

Harrington, W.H. 1884. Injurious insects infesting the hickory. Annual Report of the Entomological Society of Ontario, 14(1883): 42-52.

Harrington, W.H. 1897. Some beetles occurring upon beech. Annual Report of the Entomological Society of Ontario, 27(1896): 69-75.

Hernández-Fuentes, L.M.; Gómez-Jaimes, R.; López-Martínez, V. \& CastañedaVildozola, A. 2018. Xylophagous insects associated with Soursop (Annona muricata L.) branches, affected by Lasiodiplodia. The Southwestern Entomologist, 43(2): 543-546.

Hoffman, C.H. 1942. Annotated list of elm insects in the United States. Miscellaneous Publications United States Department of Agriculture, 466: $1-20$.

Holt, B.D. 2013. A preliminary checklist of the Cerambycidae and Disteniidae (Coleoptera) of Alabama. The Coleopterists Bulletin, 67(3): 241-256.

Horn, G.H. 1880. Notes on some genera of Cerambycidae with descriptions of new species. Transactions of the American Entomological Society, 8: 115-138.

Hovore, F.T. 2006. The Cerambycidae (Coleoptera) of Guatemala. In: Cano, E. Biodiversidad de Guatemala. Guatemala, Universidade del Vale de Guatemala. p. 363-378.

Hovore, F.T.; Penrose, R.L. \& Neck, R.W. 1987. The Cerambycidae or longhorned beetles of Southern Texas: a faunal survey (Coleoptera). Proceedings of the California Academy of Sciences, 44(13): 283-334.

Hubweber, L. 2008. Longhorn beetles (Coleoptera, Cerambycidae) of the Golfo Dulce region, Costa Rica. Stapfia, 88: 249-256.

ICZN (International Commission on Zoological Nomenclature). 1999. International Code of Zoological Nomenclature. London, ICZN. xxx + 306p.

Jacquelin du Val, P.N.C. 1857. Insectes. Ordre des coléoptères. In: Sagra, R. Histoire physique, politique et naturelle de I'lle de Cuba. Paris, Bertrand. v. 7, 328p.

Jaques, H.E. 1951. How to know the beetles. Dubuque, lowa, Willian C. Brown C. $865 p$.

Johnson, H.L. 1915. Coleoptera found in the vicinity of Meriden, Connecticut. Entomological News, 26(7): 307-319.

Julio, C.E.A.; Giorgi, J.A. \& Monné, M.A. 2000. Os tipos primários de Cerambycidae (Coleoptera) da coleção do Museu Nacional - Rio de Janeiro. Publicações Avulsas do Museu Nacional, 84: 1-54.

Kaston, B.J. 1938. Check List of Elm Insects. Bulletin of the Connecticut Agricultural Experiment Station, 408: 235-242.

Kirk, H.B. \& Knull, J.N. 1926. Annotated list of the Cerambycidae of Pennsylvania. The Canadian Entomologist, 58(2): 39-46.

Klingeman, W.E; Youssef, N.N.; Oliver, J.B. \& Basham, J.P. 2017. The longhorned beetles (Coleoptera: Cerambycidae) of Tennessee: distribution of species, seasonal adult activity, and new state records. Florida Entomologist, 100(2): 292-302.

Klug, J.C. 1829. Preis-Verzeichniss vorrathiger Insecten-doubletten des Konigl. Berlin, Zoologischen Museums der Universität. 18p.

Knobel, E. 1895. Beetles of New England and their kind. A guide to know them readily. Boston, Bradlee Whidden. 45p.

Knull, J.N. 1944. New Coleoptera with notes (Buprestidae and (erambycidae). Ohio Journal of Science, 44(2): 90-93.

Knull, J.N. 1946. The long-horned beetles of Ohio (Coleoptera, Cerambycidae). Bulletin of the Ohio Biological Survey, 39: 133-354.

Knull, J.N. 1958. One new species and one subspecies of Cerambycidae from Texas (Coleoptera). Ohio Journal of Science, 58(5): 282.
Lacordaire, J.T. 1872. Histoire Naturelle des Insectes. Genera des Coléoptères, ou exposé méthodique et critique de tous les genres proposés jusquici dans cet ordre d'insectes. Paris, Librairie Encyclopédique de Roret. v. 9, pt. 2, p. 411-930.

Lameere, A.A. 1883. Liste des cérambycides, décrits postérieurement au catalogue de Munich. Annales de la Société Entomologique de Belgique, 26: 1-78.

Lameere, A.A. 1884. Longicornes recueillis par feu Camille van Volxem au Brésil et à La Plata. Annales de la Société Entomologique de Belgique, 28: 83-99.

Lanuza-Garay, A. \& Barrios, H. 2015. Plantas hospederas de Cerambycidae (Coleoptera, Chrysomeloidea) del paisaje protegido de Isla Galeta, Colón, Panamá. Scientia, Panama, 25(2): 63-71.

LeConte, J.L. 1852. An attempt to classify the longicorn Coleoptera of the part of America, north of Mexico. Journal of the Academy of Natural Sciences of Philadelphia, 2(2): 139-178.

LeConte, J.L. 1873. Classification of the Coleoptera of North America. Part II. Smithsonian Miscellaneous Collections, 11(265): 279-348.

LeConte, J.L. 1880. The coleopterous parasites of the common hickory (Carya tomentosa). The American Entomologist (n.s.), 3(10): 236-237.

LeConte, J.L. 1891. The complete writings of Thomas Say on the entomology of North America. Philadelphia, A.E. Foote. v. 2. 814p.

LeConte, J.L. \& Horn, G.H. 1883. Classification of the Coleoptera of North America. Prepared for the Smithsonian Institution. Smithsonian Miscellaneous Collections, 26(507): xxxvii 1-567.

Leng, C.W. \& Hamilton, J. 1896. The Lamiinae of North America. Transactions of the American Entomological Society, 23: 101-178.

Leng, C.W. \& Mutchler, A.J. 1914. A preliminary list of the Coleoptera of the West Indies as recorded to January 1, 1914. Bulletin of the American Museum of Natural History, 33: 391-493.

Leonard, M.D. 1928. A list of the insects of New York with a list of the spiders and certain other allied groups. Memoirs of the Cornell University Agricultural Experiment Station, 101: 1-1121.

Lingafelter, S.W. \& Horner, N.V. 1993. The Cerambycidae of North Central Texas. The Coleopterists Bulletin, 47(2): 159-191.

Lingafelter, S.W.; Nearns, E.H.; Tavakilian, G.L.; Monné, M.A. \& Biondi, M. 2014. Longhorned Woodboring Beetles (Coleoptera, Cerambycidae and Disteniidae) Primary types of the Smithsonian Institution. Washington. D.C., Smithsonian Institution Scholarly Press. 390p.

Linsley, E.G. \& Chemsak, J.A. 1966. Cerambycidae of Cocos Island (Coleoptera). Procedings of the California Academy of Sciences, Serie 4, 33(9): 237-248.

Linsley, E.G. \& Chemsak, J.A. 1985. The Cerambycidae of North America. Part VII, No. 1. Taxonomy and classification of the subfamily Lamiinae, tribes Parmenini through Acanthoderini. University of California, Publications in Entomology, 102: 1-258.

Linsley, E.G. \& Chemsak, J.A. 1997. The Cerambycidae of North America. Part VIII. Bibliography, Index and Host Plant Index. University of California, Publications in Entomology, 117: 1-534.

Loding, H.P. 1945. Catalogue of the beetles of Alabama. Alabama, University of Alabama. 172p. (Monograph of the Geological Survey of Alabama, 11).

Lozada Piña, A.; García, F. \& Trujillo Anaya, M. 2004. Lista preliminar de los coleópteros (Insecta, Coleoptera) de Topes de Collantes, Trinidad, Sancti Spíritus, Cuba. Boletín de la Sociedad Entomológica Aragonesa, 34: 101-106.

Luna-León, C.; Domínguez-Márquez, V.M.; Ordoñez-Reséndiz, V.M. \& MundoBahena, A. 2015. Diversidad de la família Cerambycidae (Coleoptera) de um bosque tropical caducifólio de la comunidade de Taxco el Viejo, Guerrero, México. Entomologia Mexicana, 2: 835-839. 
MacRae, T.C. 1993. Annotated checklist of the longhorned beetles (Coleoptera: (erambycidae and Disteniidae) occurring in Missouri. Insecta Mundi, 7: 223-252.

Maes, J.M. 1998. Catálogo de los insectos y artrópodos terrestres de Nicaragua. Managua, Setab Bosawas, Marena.

Maes, J.M.; Allen, A.; Monné, M.A. \& Hovore, F.T. 1994. Catálogo de los Cerambycidae (Coleoptera) de Nicaragua. Revista Nicaraguense de Entomologia, 27: 1-58.

Maes, J.M.; Berghe, E.; Dauber, D.; Audureau, A.; Nearns, E.; Skilman, F.; Heffern, D. \& Monné, M.A. 2010. Catálogo ilustrado de los Cerambycidae (Coleoptera) de Nicaragua. Parte IV - Lamiinae - Disteniinae. Revista Nicaraguense de Entomologia, 70(Supl. 1-4): 1-879.

Martins, U.R.\& Santos-Silva, A. 2013. Transfers, new records and redescriptions in Lamiinae (Coleoptera, Cerambycidae). Les Cahiers Magellanes (NS), 13: $12-20$.

Martins, U.R.; Santos-Silva, A. \& Galileo, M.H.M. 2015. Fourteen new species, one new genus, and eleven new country or state records for New World Lamiinae (Coleoptera, Cerambycidae). Zootaxa, 3980(1): 81-105.

Martorell, L.F. 1939. Insects observed in the State of Aragua, Venezuela, South America. Journal of the Agriculture University of Puerto Rico, 23(4): 177-232.

Melsheimer, F.E. 1853. Catalogue of the described Coleoptera of the United States. Washington, Smithsonian Institution. 174p.

Melzer, J. 1932. Vinte espécies novas de cerambycideos neotrópicos, principalmente do Brasil. Revista de Entomologia, 2(2): 216-238.

Mermudes, J.R.M. \& Monné, M.L. 2001. Descrição da larva e pupa de Acanthoderes (Psapharochrus) melanosticta White, 1855 (Coleoptera, Cerambycidae, Lamiinae, Acanthoderini). Revista Brasileira de Entomologia, 45(4): 331-334.

Monné, M.A. 1994. Catalogue of the Cerambycidae (Coleoptera) of the Western Hemisphere. Part XVII. Subfamily Lamiinae: Tribes Anisocerini, Polyrhaphidini, Xenofreini, Acrocinini and Acanthoderini. São Paulo, Sociedade Brasileira de Entomologia. 110p.

Monné, M.A. 2001. Catalogue of the Neotropical Cerambycidae (Coleoptera) with known host plant - Part III: Subfamily Lamiinae, Tribes Acanthocinini to Apomecynini. Publicações Avulsas do Museu Nacional, 92: 1-94.

Monné, M.A. 2005. Catalogue of the Cerambycidae (Coleoptera) of the Neotropical Region. Part II. Subfamily Lamiinae. Zootaxa, 1023: 1-759.

Monné, M.A. 2019. Catalogue of the Cerambycidae (Coleoptera) of the Neotropical region. Part II. Subfamily Lamiinae. Available at: http:// cerambyxcat.com. Access in: 08/2019.

Monné, M.A. \& Chaboo, C.S. 2015. Beetles (Coleoptera) of Peru: A Survey of the Families. Cerambycidae, Disteniidae, Vesperidae. Journal of the Kansas Entomological Society, 88(1): 34-120.

Monné, M.A. \& Giesbert, E.F. 1992. Nomenclatural notes on Western Hemisphere Cerambycidae (Coleoptera). Insecta Mundi, 6(2): 249-255.

Monné, M.A. \& Giesbert, E.F. 1994. Checklist of the Cerambycidae and Disteniidae (Coleoptera) of the Western Hemisphere. Burbank, Wolfsgarden Books. 409p.

Monné, M.A.\& Hovore, F.T. 2006. A Checklist of the Cerambycidae, or longhorned wood-boring beetles, of the Western Hemisphere. Rancho Domingues, Bio Quip Publications. 393p.

Monné, M.A. \& Monné, M.L. 2016. Checklist of Cerambycidae (Coleoptera) primary types of the Museu Nacional, Rio de Janeiro, Brazil, with a brief history of the collection. Zootaxa, 4110(1): 1-90.

Monné, M.A.; Nearns, E.H.; Carbonel, S.H.; Swift, I.P. \& Monné, M.L. 2012. Preliminary checklist of the Cerambycidae, Disteniidae, and Vesperidae (Coleoptera) of Peru. Insecta Mundi, 213: 1-48.

Monné, M.L. \& Monné, M.A. 2006. Notes on Acanthoderini (Coleoptera, (erambycidae, Lamiinae) described by Ernst Fuchs, now in the Herbert Schmid Collection, Vienna, Austria. Zootaxa, 1365: 37-47.
Monné, M.L.; Monné, M.A. \& Wang, Q. 2017. Chapter 1. General Morphology, Classification, and Biology of Cerambycidae. In: Wang, Q. Cerambycidae of the World: Biology and Pest Management. Boca Raton, CRC Press. 642p.

Monné, M.L.; Monné, M.A.; Martins, R.S.; Simões, M.V.P.\& Machado, V.S. 2010. Espécies de Cerambycidae (Insecta, Coleoptera) ocorrentes no Estado do Rio de Janeiro (Brasil). Arquivos do Museu Nacional, 67(3-4): 235-251.

Morales-Morales, C.J.; Aguilar-Astudillo, E; Rosales-Esquinca, M.A.; QuirogaMadrigal, R.R.; Alonso-Bran, R.A. \& Gutiérrez-Hernández, R.C. 2012. Cerambícidos (Coleoptera, Cerambycidae) asociados al piñon (Jatropha curcas L.), en cinco municípios de la Depresión Central de Chiapas, México. Biota Colombiana, 13(1): 35-46.

Nicolay, A.S. 1919. A list of the Buprestidae and Cerambycidae taken on Long Island, N.Y. Bulletin of the Brooklyn Entomological Society, 14(2): 63-72.

Noguera, F.A. \& Chemsak, J.A. 1996. Cerambycidae (Coleoptera). In: Biodiversidad taxonomía, y biogeografía de artrópodos de Mexico: Hacia una síntesis de su conocimiento. México, D.F., Universidad Nacional Autónoma de México. p. 381-409.

Noguera, F.A.; Ortega-Huerta, M.A.; Zaragoza-Caballero, S.; GonzálezSoriano, E. \& Ramírez-García, E. 2017. Species richness and abundance of Cerambycidae (Coleoptera) in Huatulco, Oaxaca, Mexico; relationships with phenological changes in the Tropical Dry Forest. Neotropical Entomology, 47(4): 457-469.

Noguera, F.A.; Ortega-Huerta, M.A; Zaragoza-Caballero, S.; González-Soriano, E. \& Ramírez-García, E. 2009. A faunal study of Cerambycidae (Coleoptera) from one region with tropical dry forest in Mexico: Sierra de San Javier, Sonora. The Pan-Pacific Entomologist, 85(2): 70-90.

Noguera, F.A.;Zaragoza-Caballero,S; Chemsak, J.A.; Rodriguez-Palafox, A.; Ramírez, E.; González-Soriano, E. \& Ayala, A. 2002. Diversity of the family Cerambycidae (Coleoptera) of the Tropical Dry Forest of Mexico, I. Sierra de Huautla, Morelos. Annals of the Entomological Society of America, 95(5): 617-627.

Ordóñez-Reséndiz, M.M. \& Martínez-Ramos, Y. 2017. Diversidad y fenologia de Cerambycidae (Insecta, Coleoptera) em bosques de la Sierra de Taxco, México. Entomologia Mexicana, 4: 826-831.

Packard, A.S. 1881. Insects injurious to forest and shade trees. Bulletin of the United States Entomological Commission, 7: 1-275.

Packard, A.S. 1890. Insects injurious to forest and shade trees. Bulletin of the United States Entomological Commission, 7: 1-955.

Pascoe, F.P. 1866. List of the Longicornia collected by the late Mr. P. Bouchard, at Santa Marta. The Transactions of the Entomological Society of London, 1866: 279-296.

Pechuman, L.L. 1937. An annotated list of insects found in the bark and wood of Ulmus americana L. in New York State. Bulletin of the Brooklyn Entomological Society, 32(1): 8-21.

Peck, S.B. 2005. A checklist of the beetles of Cuba with data on distributions and bionomics. (Insecta, Coleoptera). Arthropods of Florida and neighboring land areas, 18: 1-214.

Peck,S.B.\&Thomas, M.C. 1998. Adistributional checklist of the beetles (Coleoptera) of Florida. Arthropods of Florida and neighboring land areas, 16: 1-180.

Perrault, G.H. 1978. Peuplement entomologique des Marquises. Cahiers $d u$ Pacifique, 21: 359-388.

Pittier, H. \& Biolley, P. 1895. Invertebrados de Costa Rica I. Coleópteros. San José, Instituto Físicogeográfico Nacional. 40p.

Rice, M.E. \& Enns, W.R. 1981. The longhorned beetle subfamily Lamiinae (Coleoptera, Cerambycidae) in Missouri. Transactions of the Missouri Academy of Sciences, 15: 89-109.

Riley, C.V. 1880. Food habits of the longicorn beetles or woodborers. The American Entomologist, 3(11): 270-271.

Santos-Silva, A. \& Nascimento F.E.L. 2018. Synonymies, transferences, redescriptions and new species in Lamiinae (Coleoptera, Cerambycidae). Zootaxa, 4462(2): 192-210. 
Santos-Silva, A.; Botero, J.P. \& Le Tirant, S. 2018. A new genus, four new species and taxonomic and geographic notes in Mexican Cerambycidae. Zootaxa, 4420(2): 189-210.

Say, T. 1831. Descriptions of new species of North American insects found in Louisiana by Joseph Barabino. New Harmony, School Press. 19p.

Say, T. 1835. Descriptions of New North American coleopterous insects, and observations on some already described. Boston Journal of Natural History, 1(2): 151-203.

Schiefer, T.L. 1998. A preliminary list of the Cerambycidae and Disteniidae (Coleoptera) of Mississippi. Transactions of the American Entomological Society, 124(2): 113-131.

Schottfeldt, C.S. 1944. Insetos encontrados em plantas cultivadas e comuns, Viçosa, Minas Gerais. Ceres, 6(32): 108-127.

Shufeldt, R.W. 1884. Observations upon a collection of insects made in the vicinity of New Orleans, Louisiana, during the years 1882 and 1883. Proceedings of the United States National Museum, 7(21-22): 331-338.

Silva, A.G. d'Araujo; Gonçalves, C.R.; Galvão, D.M; Gonçalves, A.J.L; Gomes, J.; Silva, M.N. \& Simoni, L. 1968. Quarto catálogo dos insetos que vivem nas plantas do Brasil. Seus parasitos e predadores. Vol. 1(2). Ministério de Agricultura, Rio de Janeiro, 622p.

Smith, J.B. 1900. Insects of New Jersey. A list of the species occurring in New Jersey, with notes on those of economic importance. Annual Report of the State Board of Agriculture, Supplement, 1899(27): 1-755.

Smith, J.B. 1910. A report of the insects of New Jersey. Annual Report of the New Jersey State Museum, 1909: 1-888.

Solomon, J.D.; Doolittle, R.E. \& Spilman, J.T. 1976. Cerambycid beetles captured in sticky-traps in Mississippi. The Coleopterists Bulletin, 30(3): 289-290.

Swift, I.P.; Bezark, L.G.; Nearns, E.H.; Solís, A. \& Hovore, F.T. 2010. Checklist of the Cerambycidae (Coleoptera) of Costa Rica. Insecta Mundi, 131: 1-68.

Tavakilian, G.L. 2018. New nomenclatural changes for 2018 (Coleoptera, Cerambycidae). Les Cahiers Magellanes (NS), 30: 38-43.

Tavakilian, G.L. \& Chevillotte, H. 2019. Titan: base de données internationales sur les Cerambycidae ou Longicornes. Available at: http://titan.gbif.fr/ index.html. Access in: 08/2019.

Terrón, S.R.A. 1997. Cerambyciae. In: Gonzáles Soriano, E.; Dirzo, R. \& Vogt, R.C. (Ed.). Historia Natural de Los Tuxtlas, Mexico, Universidad Nacional Autonoma do Mexico. p. 215-226.

Thomas, M.C.; Turnbow, R.H. \& Steiner, W. 2013. An annotated checklist of the Coleoptera (Insecta) of the Cayman Islands, West Indies. Insecta Mundi, 280: 1-56.

Thomson, J. 1861. Essai d'une classification de la famille des cérambycides et matériaux pour servir a une monographie de cette famille. Paris, BouchardHuzard. p. 129-396.

Thomson, J. 1864. Systema cerambycidarum ou exposé de tous les genres compris dans la famille des cérambycides et familles limitrophes. Mémoires de la Société Royale des Sciences de Liège, 19: 1-352.

Thomson, J. 1865. Diagnoses d'espèces nouvelles qui seront décrites dans l'appendix du systema cerambycidarum. Systema cerambycidarum ou exposé de tous les genres compris dans la famille des cérambycides et familles limitrophes. Liége, H. Dessain. p. 353-578.

Thomson, J. 1878. Typi cerambycidarum Musei Thomsoniani. Paris, E. Deyrolle. 21p.

Townsend, C.H.T. 1884. Notes on some Coleoptera taken in South Louisiana. Psyche, 4(126-129): 219-222.

Townsend, C.H.T. 1885. A list of Coleoptera collected in Louisiana, on or south of Parallel 30. The Canadian Entomologist, 17(4): 66-73.

Turnbow, R.H. \& Franklin, R.T. 1980. An annotated checklist of the Cerambycidae of Georgia (Coleoptera). Journal of the Georgia Entomological Society, 15: 337-349.

Turnbow, R.H.; R.D. Cave \& Thomas, M.C. 2003. A list of the Cerambycidae of Honduras, with additions of previously unrecorded species. Ceiba, 44(1): 1-43.
Ulke, H. 1903. A list of the beetles of the District of Columbia. Proceedings of the United States National Museum, 25(1275): 1-57.

Vargas-Cardoso, 0.R.; Corona-López, A.M.; López-Martínez, V.; Flores-Palacios, A.; Figueroa-Brito, R. \& Toledo-Hernández, V.H. 2018. New host records of Cerambycidae (Coleoptera) from central Mexico. Pan-Pacific Entomologist, 94(2): 91-102.

Vlasak, J. \& Vlasakova, K. 2002. Records of Cerambycidae (Coleoptera) in Massachusetts with notes on larval hosts. The Coleopterists Bulletin, 56(2): 203-219.

Wappes, J.E. \& Arias, J.L. 2016. Updated list of Coleoptera holotypes in Museo de Historia Natural, Noel Kempff Mercado, Universidad Autónoma "Gabriel Rene Moreno", Santa Cruz de la Sierra, Bolivia. Insecta Mundi, 497: 1-27.

Wappes, J.E.; Lingafelter, S.W.; Monné, M.A. \& Arias, J.L. 2013. Additions to the known Vesperidae and Cerambycidae (Coleoptera) of Bolivia. Insecta Mundi, 0319: 1-28.

Wappes, J.E.; Morris, R.F.; Nearns, E.H. \& Thomas, M.C. 2006. Preliminary list of Bolivian Cerambycidae (Coleoptera). Insecta Mundi, 20(1-2): 1-45.

White, A. 1855. Catalogue of the coleopterous insects in the collection of the British Museum. Longicornia 2. Fam. 2Cerambycidae. London, Order of the Trustees. v. 8: 175-412.

Wickham, H.F. 1897. The Coleoptera of Canada. The Cerambycidae of Ontario and Quebec. The Canadian Entomologist, 29(9): 201-208.

Wolcott, G.N. 1948. The insects of Puerto Rico. Coleoptera. Journal of Agriculture of the University of Puerto Rico, 32(2): 225-416.

Yanega, D. 1996. Field guide to northeastern longhorned beetles (Coleoptera, (erambycidae). Manual 6. Illinois Natural History Survey, Champaign, 174p.

Zajciw, D. 1963. Novas espécies neotrópicas do gênero Acanthoderes Serville, 1835. I. (Coleoptera, Cerambycidae, Lamiinae). Anais da Academia Brasileira de Ciências, 35(4): 585-590.

Zajciw, D. 1964. Novas espécies neotrópicas do gênero Acanthoderes Serville, 1835. III (Coleoptera, Cerambycidae, Lamiinae). Anais da Academia Brasileira de Ciências, 36(2): 159-164.

Zajciw, D. 1966. Contribuição para o estudo da fauna dos longicórneos do Estado do Ceará. (Coleoptera, Cerambycidae). Boletim da Sociedade Cearense de Agronomia, 7: 1-11.

Zajciw, D. 1969a. Contribuição para o estudo da distribuição geográfica do gênero Acanthoderes Serville, 1835 no Brasil (Coleoptera, Cerambycidae, Lamiinae). Atas da Sociedade de Biologia, 12(4): 197-199.

Zajciw, D. 1969b. Distribuição geográfica do gênero "Acanthoderes" Serville, 1835 (Coleoptera, Cerambycidae, Lamiinae). Revista Brasileira de Biologia, 29(4): 607-614.

Zajciw, D. 1970a. Novas ocorrências de Acanthoderes Serv., 1835. II (Col., (erambycidae, Lamiinae). Atas da Sociedade de Biologia, 13(1-2): 5.

Zajciw, D. 1970b. Contribuição para o estudo das espécies do gênero Acanthoderes Serv. 1835 (Coleoptera, Cerambycidae, Lamiinae). Atas da Sociedade de Biologia, 13(5-6): 187-190.

Zajciw, D. 1971. Novos longicórneos neotrópicos. XVIII (Col., Cerambycidae). Revista Brasileira de Biologia, 31(3): 305-308.

Zajciw, D. 1974. Contribuição para o estudo da fauna dos longicórneos (Coleoptera, Cerambycidae) das florestas do Estado do Espírito Santo e principalmente da Reserva Biológica Soôretama. Boletim Técnico do Instituto Brasileiro de Desenvolvimento Florestal, 4: 37-91.

Zajciw, D. \& Seabra, C.A.C. 1968. Longicórneos da Serra da Bocaina, Estado de São Paulo (Coleoptera, Cerambycidae). Atas da Sociedade de Biologia, 12(2): 69-72.

Zaragoza-Caballero, S. \& Pérez-Hernández, C.X. 2017. An annotated catalogue of the Coleoptera types deposited in the National Insect Collection (CNIN) of the National Autonomous University of Mexico. Zootaxa, 4288(1): 1-128.

Zayas, F. 1975. Revisión de la família Cerambycidae (Coleoptera, Phytophagoidea). Habana, Academia de Ciencias de Cuba. 443p. 